\title{
SUBSÍDIOS PARA O MANEJO DA RESISTÊNCIA DE Blattella germanica (L., 1767) (Dictyoptera:Blattellidae) A INSETICIDAS
}

\author{
ELOISA SALMERON
}

\begin{abstract}
Tese apresentada à Escola Superior de Agricultura "Luiz de Queiroz", Universidade de São Paulo, para obtenção do título de Doutor em Ciências, Área de Concentração: Entomologia.
\end{abstract}

PIRACICABA

Estado de São Paulo - Brasil

Janeiro - 2002 


\title{
SUBSÍDIOS PARA O MANEJO DA RESISTÊNCIA DE Blattella germanica (L., 1767) (Dictyoptera:Blattellidae) A INSETICIDAS
}

\section{ELOISA SALMERON}

Engenheiro Agrônomo

Orientador: Prof. Dr. CELSO OMOTO

\begin{abstract}
Tese apresentada à Escola Superior de Agricultura "Luiz de Queiroz", Universidade de São Paulo, para obtenção do título de Doutor em Ciências, Área de Concentração: Entomologia.
\end{abstract}

PIRACICABA

Estado de São Paulo - Brasil

Janeiro - 2002 


\section{Dados Internacionais de Catalogação na Publicação (CIP)}

DIVISÃO DE BIBLIOTECA E DOCUMENTAÇÃO - ESALQ/USP

Salmeron, Eloisa

Subsídios para o manejo da resistência de Blattella germanica (L., 1767)

(Dictyoptera : Blattellidae) a inseticidas /

$118 \mathrm{p}$.

Tese (doutorado) - Escola Superior de Agricultura Luiz de Queiroz, 2002.

Bibliografia.

1. Baratas 2. Entomologia urbana 3. Resistência ao pesticida I. Título

CDD 632.722

\section{"Permitida a cópia total ou parcial deste documento, desde que citada a fonte - $O$ autor"}


Aos meus pais Antonio (in memorium) e Mercedes

Pela educação recebida

Aos meus irmãos e cunhadas

Pela paciência e incentivo recebidos

Agradeço.

Aos meus sobrinhos Arnaldo Jr., Samira, Paola, Sintia e Eduardo

Para que sirva de estímulo para o futuro

Dedico. 


\section{AGRADECIMENTOS}

Ao Prof. Dr. Celso Omoto pela orientação, confiança e oportunidades que me foram dadas no decorrer deste trabalho.

Ao Prof. Dr. Gilberto Casadei de Baptista do setor de Entomologia da ESALQ/USP, pelo apoio inicial na realização deste trabalho.

À Fundação de Amparo à Pesquisa do Estado de São Paulo (FAPESP) pelo apoio financeiro para a realização desta pesquisa.

Ao Conselho Nacional de Desenvolvimento Científico e Tecnológico (CNPq) pela concessão de bolsa durante a realização do curso de pós-graduação.

Ao colega Sr. Oscar R. P. Bendeck da Aventis Environmental Science pela amizade e valiosos ensinamentos prestados.

À Aventis Environmental Science e à Dow AgroSciences pelo fornecimento dos inseticidas para a realização deste experimento.

A todos os colegas do laboratório de Resistência de Artrópodes a Pesticidas pelas sugestões dadas.

A todas as pessoas que de alguma forma contribuíram para a realização deste trabalho. 


\section{SUMÁRIO}

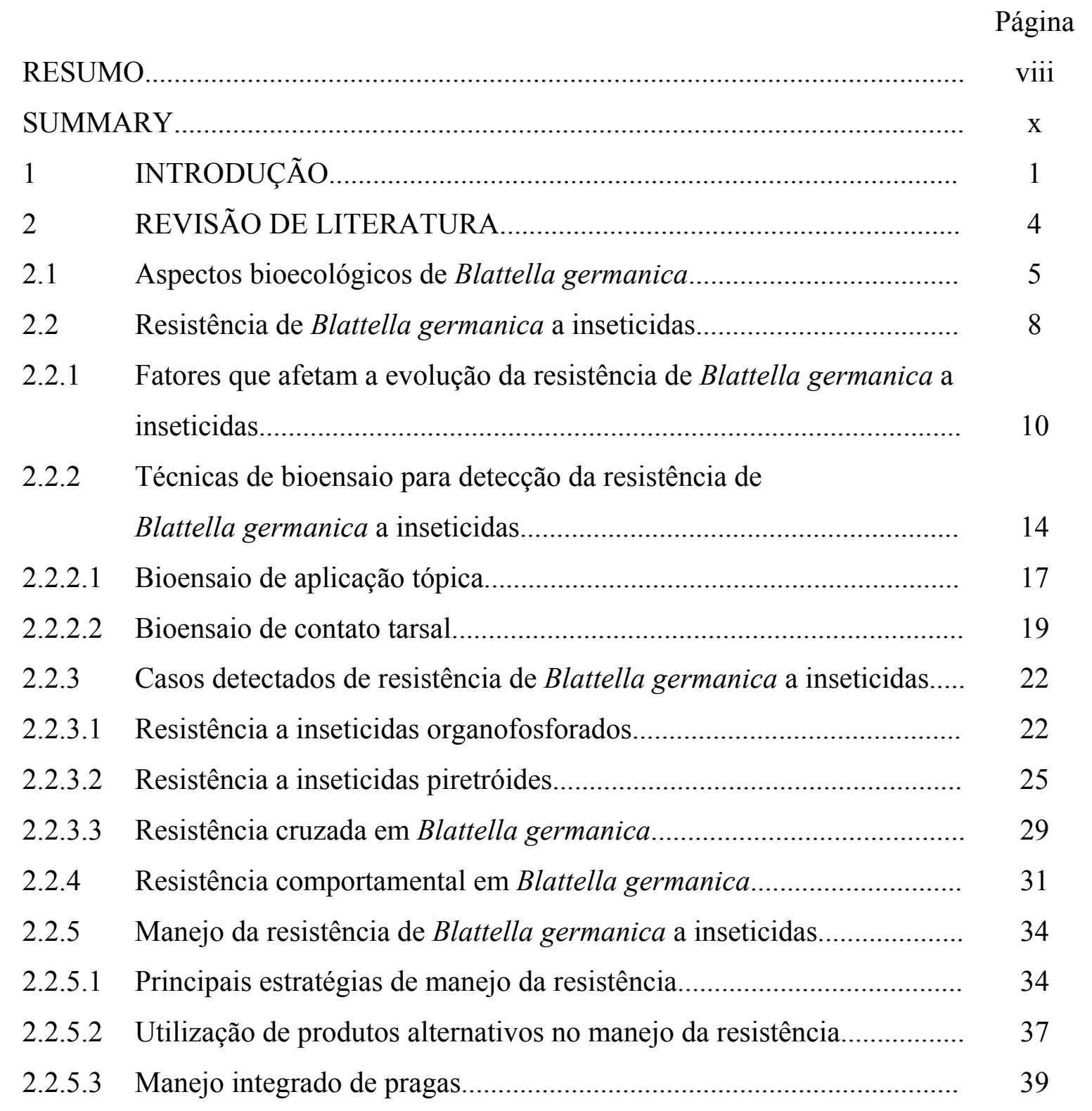


MONITORAMENTO DA SUSCETIBILIDADE DE POPULAÇÕES

DE Blattella germanica (L., 1767) (Dictyoptera: Blattellidae) A

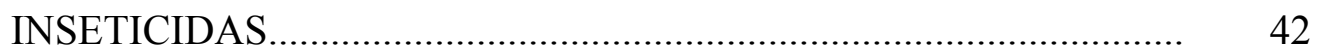

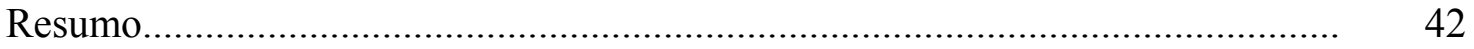

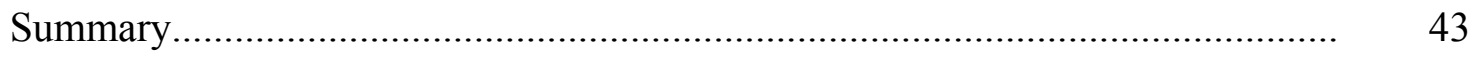

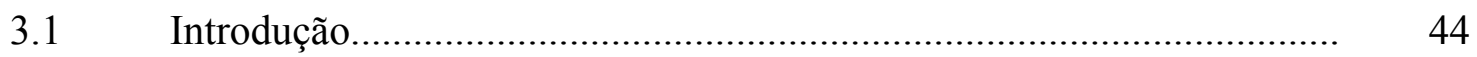

3.2 Material e Métodos..................................................................... 45

3.2.1 Coleta de populações de Blattella germanica........................................... 45

3.2.2 Criação de Blattella germanica em laboratório.......................................... 46

3.2.3 Técnicas de bioensaio para detecção da resistência de

Blattella germanica a inseticidas......................................................... 46

3.2.3.1 Bioensaio de aplicação tópica................................................................. 48

3.2.3.2 Bioensaio de contato tarsal................................................................. 49

3.2.4 Monitoramento da suscetibilidade de populações de

Blattella germanica a deltametrina, clorpirifós e fipronil....................... 50

3.3 Resultados e Discussão................................................................. 50

3.3.1 Técnicas de bioensaio para detecção da resistência de Blattella

germanica a inseticidas.................................................................... 50

3.3.1.1 Bioensaio de aplicação tópica............................................................... 50

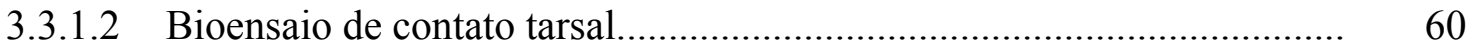

3.3.2 Monitoramento da suscetibilidade de populações de

Blattella germanica a deltametrina, clorpirifós e fipronil........................ 66

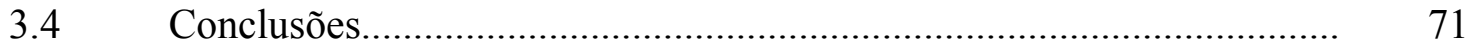

4 CARACTERIZAÇÃO DA RESISTÊNCIA DE Blattella germanica

(L., 1767) (Dictyoptera: Blattellidae) A DELTAMETRINA E

CLORPIRIFÓS E RELAÇÕES DE RESISTENCIA CRUZADA

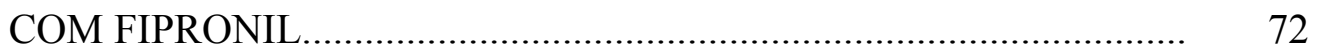

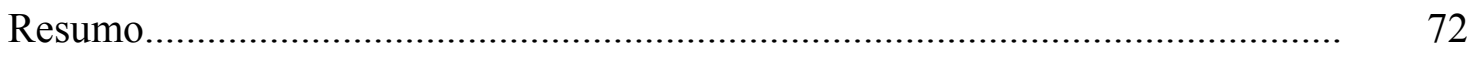

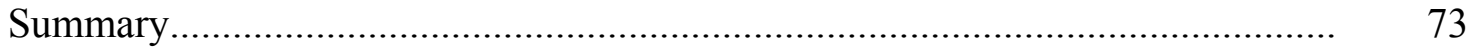

4.1 Introdução..................................................................................... 


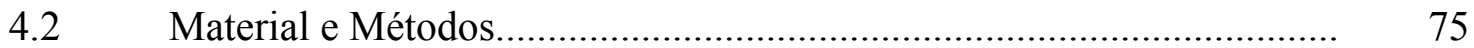

4.2.1 Caracterização da resistência de Blattella germanica a deltametrina e clorpirifós.

4.2.2 Dinâmica da resistência de Blattella germanica a deltametrina.............. 77

4.2.3 Relações de resistência cruzada com o inseticida fipronil........................ 78

4.3 Resultados e Discussão........................................................................ 78

4.3.1 Caracterização da resistência de Blattella germanica a deltametrina e clorpirifós................................................................................. 78

4.3.2 Dinâmica da resistência de Blattella germanica a deltametrina.............. 83

4.3.3 Relações de resistência cruzada com o inseticida fipronil...................... 85

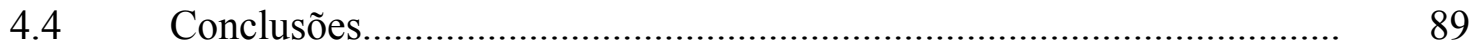

5 MISTURA DE DELTAMETRINA E CLORPIRIFÓS NO MANEJO

DA RESISTÊNCIA DE Blattella germanica (L., 1767) (Dictyoptera: Blattellidae) A DELTAMETRINA........................................................ 90

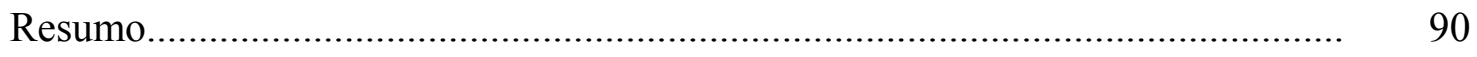

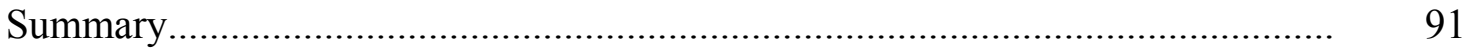

5.1 Introdução......................................................................... 92

5.2 Material e Métodos............................................................................ 93

5.3 Resultados e Discussão..................................................................... 94

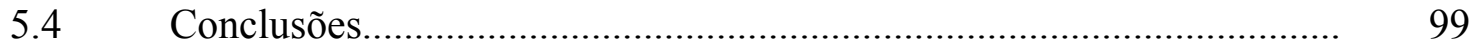

$6 \quad$ CONCLUSÕES GERAIS.................................................................... 100

REFERÊNCIAS BIBLIOGRÁFICAS.............................................................. 101

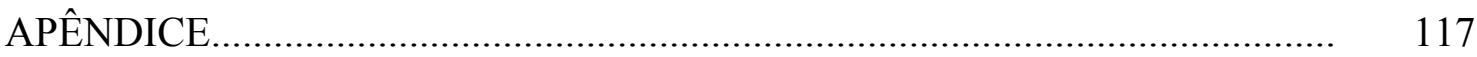




\title{
SUBSÍDIOS PARA O MANEJO DA RESISTÊNCIA DE Blattella germanica (L., 1767) (Dictyoptera: Blattellidae) A INSETICIDAS
}

\author{
Autor: Eloisa Salmeron \\ Orientador: Prof. Dr. Celso Omoto
}

\section{RESUMO}

Bases para a implementação de um programa de manejo da resistência de Blattella germanica (L.) a inseticidas foram coletadas no presente trabalho. Técnicas de bioensaio de aplicação tópica e de contato tarsal foram comparadas inicialmente para a detecção da resistência a deltametrina e clorpirifós. O bioensaio de aplicação tópica possibilitou uma melhor discriminação entre a linhagem suscetível e as populações de campo de $B$. germanica testadas. Resultados do monitoramento da suscetibilidade de $B$. germanica a inseticidas evidenciaram a presença de variabilidade genética que confere resistência a deltametrina, clorpirifós e fipronil em populações coletadas em alguns estabelecimentos comerciais dos Estados de São Paulo e Rio de Janeiro. As razões de resistência encontradas para deltametrina e clorpirifós foram de aproximadamente 43 e 6 vezes, respectivamente. A resistência de $B$. germanica a deltametrina foi instável, ou seja, houve uma redução significativa na freqüência de resistência na ausência de pressão de seleção. Estudos de relações de resistência cruzada revelaram uma baixa intensidade de resistência cruzada (aproximadamente 2 vezes) entre fipronil e os inseticidas deltametrina e clorpirifós. E por último, a mistura de deltametrina e clorpirifós foi avaliada para o controle de linhagens de B. germanica resistentes a deltametrina. A mistura proporcionou um melhor controle da linhagem suscetível do que 
os produtos utilizados isoladamente. No entanto, a discriminação entre as linhagens suscetível e resistente a deltametrina foi evidente com a mistura nas doses recomendadas comercialmente, o que inviabilizaria o emprego desta estratégia no manejo da resistência de B. germanica a deltametrina. 


\title{
BASES FOR MANAGING THE RESISTANCE OF Blattella germanica (L., 1767) (Dictyoptera: Blattellidae) TO INSECTICIDES
}

\author{
Author: Eloisa Salmeron \\ Adviser: Prof. Dr. Celso Omoto
}

\section{SUMMARY}

Bases for implementing a resistance management program of Blattella germanica (L.) to insecticides were collected in this study. Initially, we compared the topical and residual tarsal-contact bioassays for detecting resistance to deltamethrin and chlorpyrifos. The topical bioassay gave better discrimination between susceptible and field-collected populations of $B$. germanica. Results from a survey of the susceptibility of $B$. germanica to insecticides revealed the presence of genetic variability that confers resistance to deltamethrin, chlorpyrifos and fipronil in field-collected populations of $B$. germanica from the States of São Paulo and Rio de Janeiro. The resistance ratios to deltamethrin and chlorpyrifos were approximately 43 and 6-fold, respectively. The resistance of $B$. germanica to deltamethrin was unstable; that is, a significant reduction in the frequency of resistance was detected under absence of selection pressure. Studies on cross-resistance relationships showed a low intensity of cross-resistance (approximately 2-fold) between fipronil and the insecticides deltamethrin and chlorpyrifos. And finally, the viabilility of the use of deltamethrin and chlorpyrifos mixture was evaluated for controlling deltamethrin-resistant strains of B. germanica. The use of mixtures gave better control of the susceptible strain than the use of the 
products by itself. However, the discrimination between susceptible and resistant strains was clear with the use of mixtures at recommended rates, which impairs the use of this strategy for managing $B$. germanica resistance to deltamethrin. 


\section{INTRODUÇÃO}

A urbanização é um produto do crescimento populacional humano e da industrialização e com isso, tanto em países industrializados como em desenvolvimento tem afastado os homens de muitas pragas, mas mantido em íntima associação com outras. Algumas espécies de baratas, as chamadas domiciliares, domésticas, domissanitárias, urbanas ou sinantrópicas tornaram-se adaptadas a viver em uma associação bastante próxima ao homem em residências, restaurantes, hotéis, supermercados, armazéns e outras estruturas, se alimentando de uma variedade de itens de forma que a sua presença é sempre tida como uma ameaça à saúde humana (Paganelli, 1997).

As baratas constituem um grupo de insetos muito antigo e bem sucedido e estão no globo terrestre há aproximadamente 350 milhões de anos (cerca de 150 milhões antes dos dinossauros). Sua morfologia, biologia e comportamento tem permitido várias espécies de explorarem um número variado de hábitats desde as dunas de areia do sudoeste dos Estados Unidos até cavernas de Madagascar (Appel, 1995).

As baratas, especialmente a barata alemã - Blattella germanica (L., 1767) (Dictyoptera: Blattellidae), assumem um papel de grande importância na saúde pública, pois o combate a esse inseto visa fundamentalmente prevenir a transmissão de agentes infecciosos por via mecânica e/ou biológica. A conscientização e a cooperação da população frente aos problemas causados pelas baratas à saúde humana são um componente essencial em qualquer programa de controle. 
Apesar de rigorosas medidas de sanitização e dos procedimentos de manejo não químicos recomendados, o controle de baratas comumente requer uma seleção e cuidadosa aplicação de inseticida. Neste caso, os inseticidas piretróides assumem importância significativa pela frequência com que são utilizados (Cochran, 1994a), devido principalmente ao rápido efeito e ao baixo odor que deixam durante e após as aplicações, e os inseticidas organofosforados por oferecerem um maior período residual de controle.

Os inseticidas ocupam lugar de destaque na agricultura, na pecuária e na saúde pública, sendo necessário um bom conhecimento dos mesmos, as maneiras de aplicá-los, a toxicidade e as formulações. $\mathrm{O}$ uso indiscriminado de produtos químicos geralmente acaba gerando efeitos colaterais, como por exemplo intoxicações e evolução da resistência. Falhas nas técnicas de aplicação, uso de equipamentos inadequados ou a falta de seleção criteriosa dos princípios ativos podem levar à redução aparente de focos das pragas, que ressurgem após períodos de descontinuidade dos cuidados iniciais.

Mundialmente, a resistência de pragas a produtos químicos tem se tornado um problema bastante sério. Desde o advento dos inseticidas organoclorados nos anos 40, uma classe de inseticida é perdida, em média, a cada 10 anos, devido ao uso indevido e consequente desenvolvimento da resistência dos insetos a estes inseticidas. A resistência a inseticidas em baratas, embora um problema existente há muito tempo, tem assumido a maior importância nos últimos anos por causa do aumento do número de estabelecimentos tratados e quantidades excessivas de inseticidas utilizados, nem sempre apresentando um resultado satisfatório no controle, o que faz com que a população de baratas aumente ainda mais. Muitos desses locais estão continuamente sob tratamento com inseticidas, o que aumenta o risco da resistência, especialmente em $B$. germanica. $\mathrm{O}$ desenvolvimento da resistência de $B$. germanica a inseticidas está sendo um dos grandes entraves no seu controle e grandes quantidades de inseticidas, assim como misturas excessivas estão sendo aplicadas anualmente, sem obter resultados plenamente satisfatórios em algumas situações (Omoto, 1996).

A principal arma para conter essa resistência tem sido o uso de produtos químicos alternativos com estruturas químicas diferentes que não sejam afetados pela 
resistência cruzada (Georghiou, 1986). A redução gradual de substâncias químicas disponíveis tem revelado uma limitação nessa prática e enfatizado a necessidade de maximizar a vida útil de novos produtos químicos através de suas aplicações, sob condições que previnam ou retardem o desenvolvimento da resistência. Com o problema da resistência, a necessidade e o interesse em se prolongar a vida útil dos inseticidas são evidentes, pois a descoberta e o desenvolvimento de uma nova molécula química estão se tornando cada vez mais caros e difíceis.

Apesar da grande relevância dos problemas de resistência de pragas a pesticidas, estudos nesta área são bastante carentes no Brasil (Omoto, 1996), dessa forma este trabalho foi proposto com o objetivo de fornecer subsídios para um programa de manejo da resistência em $B$. germanica aos inseticidas deltametrina e clorpirifós. Foram realizados estudos para avaliar a suscetibilidade de populações de $B$. germanica aos inseticidas deltametrina e clorpirifós, e também ao novo inseticida fipronil. Para isso, técnicas de bioensaio de aplicação tópica e de contato tarsal foram avaliadas para a detecção da resistência. Posteriormente, um monitoramento da suscetibilidade de $B$. germanica a esses inseticidas foi realizado a partir de populações coletadas em alguns estabelecimentos comerciais dos Estados de São Paulo e Rio de Janeiro para avaliar a sua variabilidade genética (capítulo 3). Posteriormente, estudos para caracterização da resistência de $B$. germanica aos inseticidas deltametrina e clorpirifós; avaliação da dinâmica da resistência de $B$. germanica a deltametrina para verificar se a resistência é instável na ausência de pressão de seleção; e relações de resistência cruzada entre fipronil, um inseticida lançado recentemente para o controle de B. germanica, e os inseticidas deltametrina e clorpirifós foram realizados (capítulo 4). E por último, foi avaliada a viabilidade de utilização da mistura de deltametrina e clorpirifós nas doses recomendadas atualmente no manejo da resistência de B. germanica a deltametrina (capítulo 5). 


\section{REVISÃO DE LITERATURA}

As baratas estão entre os insetos mais comuns encontrados no convívio humano, são causadoras de grande repugnância e consideradas uma das espécies mais adaptadas e bem sucedidas entre os animais do mundo, pois foram capazes de sobreviver a diversas mudanças geoclimáticas de nosso planeta. Existem cerca de 4.000 espécies diferentes de baratas, sendo que $1 \%$ apresenta associação com o homem, assumindo assim, uma grande importância econômica (Bennett et al., 1996). Felizmente, a grande maioria das espécies de baratas não constituem pragas domiciliares. Cerca de 50 espécies tornaram-se peridomésticas ou domésticas e apenas algumas delas constituem pragas urbanas. Grande parte das baratas são silvestres e podem ser encontradas em nichos ecológicos bastante variados. Além de habitarem as residências, vivem entre os folhiços, cascas de árvores e sob troncos caídos nas florestas temperadas e tropicais; entre os materiais trazidos pelas ondas nas praias; nas dunas de areia dos desertos; entre gramas e arbustos; em tocas de roedores e cavernas; em ninhos de aves, formigas, vespas ou cupins; ou no meio semi-aquático. As baratas domésticas podem ser encontradas em grande número em tubulações de esgoto, fossas e caixas de gordura. Podem viver e reproduzir no interior de diversos meios de transporte, como embarcações, ônibus, trens etc, dispersando-se entre localidades remotas (Paganelli, 1997).

A barata alemã - Blattella germanica (L., 1767) (Dictyoptera: Blattellidae) também conhecida como francesinha, alemãzinha ou paulistinha, dependendo da região, tem sido considerada a espécie de maior repercussão econômica e a mais proliferada no Brasil (Guimarães, 1984) e no mundo, sendo freqüentemente encontrada em todos os 
tipos de residências e estruturas, e possivelmente a mais difícil de ser controlada entre as baratas domésticas.

\subsection{Aspectos bioecológicos de Blattella germanica}

A barata alemã, Blattella germanica, é a menor das espécies de barata de importância econômica e a de maior prevalência em apartamentos, supermercados, açougues, padarias, fábricas de alimentos, lanchonetes, hospitais, cervejarias, banheiros e restaurantes. Embarcações e ônibus também podem apresentar altas infestações de $B$. germanica, embora raramente esta espécie possa sobreviver em ambientes externos.

Provavelmente, $B$. germanica originou-se no noroeste da África e de lá irradiou-se para a Europa Oriental e Ásia, e possivelmente da Europa para a América. Várias espécies de inseto são transportadas pelo homem de uma residência à outra, dentro de móveis, aparelhos domésticos, pacotes de compras e outros meios. Aviões e embarcações são os grandes responsáveis pela dispersão de várias espécies através do mundo. Estas baratas se dispersaram através do comércio e dos meios de transporte, assim como através de migrações. Muitas residências e estabelecimentos comerciais tornaram-se infestados por B. germanica quando caixas de papelão, alimentos ou outros materiais infestados foram trazidos para o seu interior (Paganelli, 1997). Foi inicialmente descrita por Linnaeus em 1767 a partir de espécies coletadas na Dinamarca, como Blatta germanica e posteriormente o gênero foi mudado para Blattella por Caudell em 1903 (Cornwell, 1968).

Essas baratas possuem tamanho pequeno (1,5 a 3,0 cm de comprimento), coloração castanho-amarelada com duas faixas longitudinais mais escuras no pronoto, com machos e fêmeas inteiramente alados. Seu ciclo de vida pode ser completado em 100 dias sob condições favoráveis de desenvolvimento. As fêmeas são ovíparas e carregam a ooteca (resultante do alargamento do $7^{\circ}$ esternito abdominal) até quase o momento da eclosão das ninfas produzindo de 4 a 8 ootecas durante sua vida. Dentro de cada ooteca existem de 24 a 48 embriões que se desenvolvem em aproximadamente 28 dias. A ooteca é delgada, com a base e parte superior paralelas, de coloração marrom 
clara e medindo cerca de $8 \mathrm{~mm}$ de comprimento, com denteações distintas contornando cada um dos ovos (Bennett et al., 1996; Cornwell, 1968 e Ross \& Mullins, 1995).

As ninfas podem abrir a ooteca ainda quando está aderida à fêmea ou ser depositada em um lugar em que as ninfas recém eclodidas possam facilmente encontrar alimento e abrigo. É a única espécie doméstica de barata que carrega a ooteca até a eclosão das ninfas. A fêmea pode produzir sua primeira ooteca aos 11 ou 12 dias de idade do estágio adulto reduzindo consideravelmente sua alimentação alguns dias antes da eclosão das ninfas. Uma nova ooteca é formada em duas semanas após a eclosão das ninfas (Bennett et al., 1996 e Cornwell, 1968).

As ninfas são de coloração mais escura (quase negro) do que os adultos e passam por 5 a 7 estágios ninfais variando de 50 a 60 dias, representando $75 \%$ da população (Bennett et al., 1996 e Cornwell, 1968).

Os acasalamentos ocorrem logo após as fềmeas tornarem-se adultas. Em poucos dias após o acasalamento inicia-se a formação da ooteca, que é visível no final do abdome da fêmea. Seu completo desenvolvimento dar-se-á em 48 horas (Bennett et al., 1996 e Cornwell, 1968). A fase adulta pode durar de 3 a 6 meses e não tem o hábito de voar, sendo que as fêmeas apresentam maior longevidade do que os machos (Bennett et al., 1996 e Cornwell, 1968). Os machos iniciam o acasalamento 3 dias após a emergência e as fêmeas 4 a 5 dias, e se elas não copularem dentro de 14 dias após a emergência, ootecas não fertilizadas serão formadas. O número médio de acasalamentos por machos é de 10 vezes sendo que a última cópula ocorre quando o macho tem em média 42 dias (11 a 95 dias) (Ross \& Mullins, 1995).

As baratas são onívoras e segundo Brenner (1995), as peças bucais mastigadoras permitiram uma adaptação mais rápida à evolução das fontes de alimento, possibilitando o consumo de uma ampla gama de materiais os quais produzimos, estocamos, consumimos, descartamos ou excretamos. A alimentação e seleção do alimento envolve quimioreceptores a qual estão localizados nas antenas e partes das peças bucais. As baratas preferem dietas ricas em carboidratos a dietas ricas em gorduras e proteínas (Cornwell, 1968) e o canibalismo pode ocorrer quando a população é exposta a deficiências nutricionais. $\mathrm{O}$ canibalismo ocorre como uma vantagem adaptativa que 
permite um ajuste da densidade populacional e pode também servir para concentrar nutrientes essenciais contido na população em pequenos grupos com maior potencial de sobrevivência.

A barata alemã é uma espécie com hábitos noturnos, quando saem de seus esconderijos em busca de água, alimento, abrigo e acasalamento, permanecendo em refúgios durante parte do dia ou outros períodos de luz. O ciclo de atividade ou ritmo circadiano geralmente varia entre 22 e 26 horas (Cochran, 1995).

As baratas podem ser observadas durante o dia quando ocorrem condições adversas especiais, tais como o excesso de população ou quando uma forma de stress está presente (falta de alimento ou água), costumam esconder-se em grandes grupos em locais próximos à fonte de alimento, e umidade, o que faz da cozinha o seu local preferido. Os adultos podem viver até um mês sem alimento, desde que haja água, mas as ninfas só resistem 10 dias em jejum total. $\mathrm{Na}$ ausência de água, as baratas morrem em duas semanas (Cornwell, 1968 e Robinson, 1996).

A importância médica das baratas é bastante expressiva (Cochran, 1999) e diversos organismos patogênicos têm sido isolados de baratas coletadas em domicílios ou peridomicílios (Koehler et al., 1990; Roth \& Willis, 1960). Entretanto, o papel das baratas como vetores de patógenos é ainda controvertido, pois não há nenhuma prova significativa de que as baratas possam transmitir microorganismos patogênicos ao homem a ponto de causar uma doença. No entanto, há evidências significativas incriminando as baratas na disseminação mecânica de patógenos, através do seu corpo, o que justifica que sejam feitos todos os esforços para a sua erradicação ou eliminação de infestações onde vivemos e onde os alimentos são preparados (Paganelli, 1997).

As baratas parecem ser naturalmente contaminadas com cerca de 40 espécies diferentes de bactérias que são patogênicas aos vertebrados. Os helmintos constituem um segundo grande grupo de organismos patogênicos aos vertebrados a qual são transmitidos e esporadicamente, os fungos também estão associados com as baratas (Cochran, 1999).

Além da perda de alimentos pelo consumo direto pelas baratas e a destruição de documentos ao se alimentarem de papéis, as baratas deixam seu odor, excretam e além 
disso elas têm o hábito desagradável de regurgitar parte do alimento parcialmente digerido defecando em intervalos regulares por onde passam, arruinando as superfícies onde entram em contato. As baratas também liberam uma secreção nauseante de sua boca e de glândulas que se abrem em seu corpo entre o $5^{\circ}$ e $6^{\circ}$ segmento abdominal, deixando um odor característico e persistente, estragando alimentos e utensílios por onde passam (Paganelli, 1997). Desta forma, perdas indiretas ocorrem ao mancharem ou contaminarem pratos, utensílios, embalagens, documentos, rótulos, roupas etc. Elas podem também destruir equipamentos eletrônicos, causar curto-circuitos, incêndios em computadores, prejuízos em laboratórios, aeronaves, embarcações etc.

\subsection{Resistência de Blattella germanica a inseticidas}

A resistência é definida como "o desenvolvimento de uma habilidade em uma linhagem de um organismo de tolerar doses de tóxicos que seriam letais para a maioria dos indivíduos da população normal (suscetível) da espécie" (World Health Organization $^{1}$ citada por Croft \& Van de Baan, 1988). A característica da resistência é passada de geração para geração onde o inseticida age como o agente de seleção.

Dentre as conseqüências drásticas da evolução da resistência estão as aplicações mais freqüentes de pesticidas, aumento na dose do produto e a substituição por outro produto geralmente de maior toxicidade (Georghiou, 1983). Estas conseqüências acabam comprometendo os programas de manejo de pragas em vista da maior contaminação do meio ambiente, destruição de organismos benéficos e elevação nos custos de controle.

A resistência de pragas a produtos químicos tem se tornado um problema bastante sério no âmbito mundial, com um gasto anual estimado de US\$ 133 milhões de dólares nos Estados Unidos e talvez US\$ 1 bilhão de dólares em todo o mundo (Prabhakaran \& Kamble, 1993). O interesse no estudo da resistência intensificou com

\footnotetext{
${ }^{1}$ WORLD HEALTH ORGANIZATION. World health expert committee on insecticides: 7 th report. 1957.88 p. (Technical Report Series, 125).
} 
o rápido desenvolvimento de casos de resistência a organoclorados, organofosforados, carbamatos e piretróides. Até o final da década de 80 foram documentados 504 espécies de insetos e ácaros resistentes a pelo menos uma classe de pesticida, sendo 56,1\% pragas de importância agrícola, 39,3\% pragas de importância médico-veterinária e 4,6\% de artrópodes benéficos. $\mathrm{O}$ aumento pronunciado do número de casos no período de $1981 \mathrm{a}$ 1989 envolve os inseticidas mais recentemente introduzidos, principalmente os inseticidas piretróides $(11,8 \%)$, organofosforados $(66,7 \%)$ e carbamatos $(30 \%)$ (Georghiou \& Lagunes-Tejeda, 1991).

A resistência a pesticidas em insetos vetores de agentes que causam doenças ao homem também tem ameaçado a saúde pública em diversos países e tem sido constatada no meio urbano, especialmente no controle de baratas, moscas e pernilongos (Georghiou, 1983 e Roush \& Tabashnik, 1990). Significativos avanços foram verificados no conhecimento da genética, fisiologia e bioquímica da resistência, mas poucos progressos têm sido realizados na formulação de medidas defensivas práticas que previnam ou retardam sua evolução. Existe um grande interesse, tanto na agricultura quanto na saúde pública, em proteger esses produtos químicos disponíveis contra o desenvolvimento da resistência.

A resistência de $B$. germanica a inseticidas está sendo um dos grandes entraves no seu controle, pois envolve diversos inseticidas pertencentes a diferentes grupos químicos e tem sido largamente documentada desde 1953, quando o primeiro caso de resistência foi detectado em Corpus Christi, Texas (EUA) ao inseticida clordane, do grupo dos ciclodienos (Cochran, 1982 e Cornwell, 1976) (Apêndice 1). Depois que os inseticidas organoclorados foram substituídos pelos inseticidas organofosforados e carbamatos ficou evidente que os casos de resistência também poderiam ser observados com esses produtos, inclusive com os piretróides que foram introduzidos posteriormente (Robinson, 1996).

A resistência aos principais grupos de inseticida (organoclorados, organofosforados, carbamatos e piretróides) em B. germanica tem sido relatada por Cochran (1987b e 1995) e muitas populações tem desenvolvido resistência a mais de um 
composto através da resistência cruzada, resultando em maiores dificuldades no seu controle.

\subsubsection{Fatores que afetam a evolução da resistência de Blattella germanica a inseticidas}

A evolução da resistência a inseticidas é governada por um complexo de eventos e fatores, principalmente intensa e repetidas aplicações de inseticidas pertencentes ao mesmo grupo químico ou que apresentem o mesmo mecanismo de ação.

Os fatores capazes de influenciar a evolução da resistência a inseticidas, atuando de forma diferente sobre os processos evolutivos são vários e podem ser agrupados em fatores genéticos, biológicos e operacionais (Georghiou \& Taylor, 1977a,b). Embora os fatores biológicos sejam extremamente importantes e o conhecimento dos mesmos auxiliem na elaboração de estratégias de manejo, como por exemplo, uma simples modificação realizada na estrutura de um prédio ou residência, de modo a interferir no ciclo de desenvolvimento da barata, tanto estes fatores como os genéticos são inerentes da espécie e de difícil manipulação e emprego no manejo da resistência. Somente os fatores operacionais podem ser manipulados pelo homem de forma a prevenir ou retardar a evolução da resistência.

Como fatores genéticos podemos relacionar: freqüência inicial dos alelos resistentes, padrão de herança da resistência, fluxo gênico e custo adaptativo. $O$ desenvolvimento da resistência é um processo pré-adaptativo, sendo que na população de insetos existe uma considerável variabilidade genética, incluindo os genes que conferem resistência a inseticidas. Inicialmente a freqüência da resistência é extremamente baixa (Roush \& McKenzie, 1987).

Uma característica da resistência é que os indivíduos resistentes apresentam um custo adaptativo, ou seja, os indivíduos resistentes são menos aptos que os indivíduos suscetíveis na ausência de pressão de seleção. Este custo adaptativo dos indivíduos resistentes pode estar associado a uma menor viabilidade total, menor fecundidade, maior tempo para o desenvolvimento, menor competitividade para o acasalamento, 
maior suscetibilidade aos inimigos naturais etc (Georghiou, 1972; Roush \& McKenzie, 1987). Populações de $B$. germanica resistentes a piretróides são facilmente coletadas no campo e criadas em laboratório (Atkinson et al., 1991), mas quando as populações são criadas na ausência de pressão de seleção com inseticidas, os níveis de resistência geralmente declinam, a menos que o gene da resistência esteja fixo na população. No entanto, poucas informações são disponíveis com relação à taxa de declínio da resistência em populações de B. germanica resistentes a inseticidas (Strong et al., 1997).

O nível de resistência de $B$. germanica em laboratório foi monitorado por Strong et al. (1997) em uma linhagem resistente a cipermetrina. A descendência de uma população coletada no campo em 1988 e criada em laboratório por 12 meses apresentaram uma $\mathrm{CL}_{50}$ de 2,29 $\mu \mathrm{g}$ cipermetrina/inseto. Em dezembro de 1989 (17 meses em criação, 7 gerações), a CL $_{50}$ declinou levemente para 2,16 $\mu \mathrm{g}$ cipermetrina/inseto. Quando essa população permaneceu no laboratório por 29 meses sem pressão de seleção com inseticidas, a $\mathrm{CL}_{50}$ declinou para 1,29 $\mu \mathrm{g}$ cipermetrina/inseto. Após seis meses (35 meses em criação, 15 gerações), a $\mathrm{CL}_{50}$ foi de $0,68 \mu \mathrm{g}$ cipermetrina/inseto mostrando um declínio significativo da resistência no decorrer do tempo.

Cochran (1993) verificou que quando a pressão de seleção foi removida de uma população de $B$. germanica selecionada com piretróides, a razão de resistência $\left(\mathrm{RR}^{2}\right)$ para cipermetrina declinou de 6,6 para 1,3 em 6 gerações. A baratas resistentes criadas em laboratório foram menos fecundas na ausência de pressão de seleção do que as baratas suscetíveis. Baratas resistentes tiveram maior período de desenvolvimento ninfal do que as baratas suscetíveis, e baratas selecionadas com DDT produziram um menor número de ninfas por fêmea e ninfas por ooteca do que populações não tratadas (Strong et al., 1997).

\footnotetext{
${ }^{2} \mathrm{RR}=$ quociente da $\mathrm{CL}_{50}$ da população em estudo pela $\mathrm{CL}_{50}$ da linhagem suscetível
} 
Zhai \& Robinson (1996) estudaram a estabilidade da resistência a 3 piretróides (cipermetrina, ciflutrina e esfenvalerato) em populações de campo de B. germanica coletadas por 13 gerações $\left(F_{1}-F_{13}\right)$ durante 3 anos, período durante a qual os insetos não foram expostos a piretróides. $\mathrm{O}$ declínio da resistência à cipermetrina na população estudada necessitou de aproximadamente o mesmo intervalo de tempo (13 gerações) necessário para a evolução da resistência. A RR à cipermetrina declinou de 180 vezes em Julho/1990 para 123 em Março/1991 ( $\left.\mathrm{F}_{2}\right)$, para 66 em Outubro/1991 ( $\left.\mathrm{F}_{5}\right)$, para $41 \mathrm{em}$ Outubro/1992 $\left(\mathrm{F}_{9}\right)$ e para 2,5 em Outubro/1993 $\left(\mathrm{F}_{13}\right)$. Para a ciflutrina, a RR de 27 vezes em 1990 declinou para 3,3 em 1993. Para o esfenvalerato, a RR de 17 vezes em 1991 declinou para 4,6 em 1993. A resistência à ciflutrina $(R R=27)$ e esfenvalerato $(R R=17)$ foi também detectada, sendo que o nível de resistência para os 2 piretróides declinou durante 10-13 gerações (1990-1993) sem exposição aos inseticidas.

Cochran (1993) mostrou o declínio da resistência a piretróides em populações de laboratório de $B$. germanica, por 15 gerações, sem nunca serem expostos a piretróides ou nenhum outro inseticida. Após 4 gerações sem seleção, a RR para cipermetrina, através do tempo para knock-down $\left(\mathrm{KD}_{50}{ }^{3}\right)$, declinou nitidamente a níveis relativamente baixos e continuou a declinar por 9 gerações. Cochran (1993) também relatou uma flutuação de 10 vezes na $\mathrm{RR}$, através do $\mathrm{KD}_{50}$, nas 6 gerações.

O custo adaptativo que ocorre como efeito pleiotrópico dos genes da resistência na ausência da pressão de seleção parece não ser fenômeno generalizado, mas influenciado pelo mecanismo de resistência (Roush \& Daly, 1990). A desvantagem adaptativa tem sido encontrada em linhagens com alto nível de resistência aos piretróides (Ross, 1992), no entanto, desvantagens associadas com a resistência podem ser melhoradas no decorrer do tempo através da coadaptação (Roush \& McKenzie, 1987).

\footnotetext{
${ }^{3} \mathrm{KD}_{50}$ - tempo para knock-down dos insetos
} 
Vários fatores biológicos têm contribuído para uma rápida evolução da resistência de $B$. germanica a inseticidas. Isso ocorre pelo fato desta espécie apresentar uma ooteca de gestação múltipla mais numerosa que o resto das baratas domésticas (em média 30 ovos); ter uma alta capacidade reprodutiva (20.000 descendentes (incluindo $2^{\mathrm{a}}$ geração)/fêmea/ano e uma capacidade de aumento da população da ordem de 27 vezes em 3 meses); ter períodos de incubação (28-30 dias) e ninfal ( \pm 2 meses com 5-7 ínstares) relativamente curtos; possuir ninfas com melhores oportunidades de sobreviverem pelo fato da fêmea carregar a ooteca durante todo o período de gestação e ainda por serem menores do que as de outras espécies o que possibilita esconderem-se em locais inacessíveis para espécies maiores (Bennett et al., 1996 e Cornwell, 1968).

Populações resistentes e suscetíveis de B. germanica foram comparadas em relação ao período de incubação, período de desenvolvimento ninfal e longevidade do adulto por diversos autores. Cochran (1995) encontrou que em 2 linhagens resistentes com desvantagens reprodutivas, a maturação ninfal levou cerca de 80 dias, comparado com 63-68 dias na linhagem suscetível e 50-60 dias em outros estudos de laboratório com linhagens presumivelmente suscetíveis. Machos e fêmeas de linhagens resistentes aos inseticidas DDT, BHC e clordane pesaram menos do que os respectivos da linhagem normal (Grayson, 1954). Por outro lado, Harmon \& Ross (1988) mostraram que fêmeas resistentes a inseticidas apresentaram uma vantagem sobre fêmeas suscetíveis com relação à resistência fisiológica, pois quando expostas ao inseticida (malation e diazinon), fêmeas resistentes freqüentemente retiveram sua ooteca, no entanto fêmeas suscetíveis liberaram sua ooteca prematuramente.

Existem também os fatores operacionais, aqueles cujos fatores são possíveis de serem manipulados pelo homem. Os fatores operacionais podem ser divididos em dois grupos: aqueles relacionados com as características do produto aplicado (grupo químico, persistência, seletividade, formulação) e aqueles relacionados com as características da aplicação (nível de controle, estágio de desenvolvimento da praga, método de aplicação, dose, estratégias para o uso de produtos químicos) (Georghiou \& Taylor, 1977b). Outros fatores que podem influenciar a estabilidade incluem o tamanho e a área geográfica 
ocupada pela população resistente, a presença de segmentos não expostos da população, e oportunidades de movimento dentro da área geográfica (Zhai \& Robinson, 1996).

\subsubsection{Técnicas de bioensaio para deteç̧ão da resistência de Blattella germanica a inseticidas}

A realização de bioensaios é necessária para poder acompanhar continuamente a suscetibilidade da população de uma praga durante um programa de manejo da resistência e detectar a resistência antes que falhas no controle sejam observadas com o uso de um determinado produto.

Quando suspeita-se da existência da resistência de uma praga a um determinado pesticida, necessita-se que sejam realizados bioensaios que avaliem a suscetibilidade da população ao inseticida, com exclusão de outros fatores que poderiam afetar a eficácia do inseticida. Existem bioensaios preconizados pela Organização Mundial de Saúde (OMS) e pela Food Agriculture Organization (FAO) que podem ser utilizados para a detecção da resistência de B. germanica a inseticidas (Brown \& Pal, 1973). Os métodos se referem à utilização de machos adultos, preservando assim as fêmeas para dar continuidade à criação.

Existem diversas técnicas de bioensaio para se estimar a resistência de $B$. germanica a inseticidas, como por exemplo bioensaio de ingestão (Silverman \& Ross, 1994); bioensaio de pulverização em azulejos (OMS); teste em arenas com vapores de inseticida (Brett \& Ross, 1986); bioensaio de aplicação tópica (Cochran, 1995; 1997; Milio et al., 1987; entre outros); bioensaio de contato tarsal com dose única ou com doses múltiplas (Cochran, 1989; 1994b; Ladonni, 2001; entre outros).

Basicamente, os métodos mais utilizados para a detecção da resistência a inseticidas em B. germanica segundo Cochran (1995; 1997); Ladonni (2001) e Milio et al. (1987) são os bioensaios de aplicação tópica, onde estima-se a dose letal ( $\mathrm{DL}_{50}$ ); o bioensaio de contato tarsal onde pode ser trabalhado com uma única dose onde estima-se o tempo letal $\left(\mathrm{TL}_{50}\right)$ ou o tempo para observação do efeito knock-down $\left(\mathrm{KD}_{50}\right)$; ou ainda o bioensaio de contato tarsal com doses múltiplas, onde estima-se o resíduo letal $\left(\mathrm{RL}_{50}\right)$. 
O nível de resistência detectado pelo uso desses métodos pode diferir apreciavelmente dentro da mesma linhagem (Cochran, 1989; Milio et al., 1987; Rust \& Reierson, 1991). Tipicamente, o método de contato tarsal onde estima-se o $\mathrm{TL}_{50}$ (tempo letal) ou $\mathrm{KD}_{50}$ (tempo para observação do efeito knock-down), resulta em razões da resistência mais baixas; o método do resíduo letal $\left(\mathrm{RL}_{50}\right)$ também chamado de método da concentração letal resulta em razão de resistência intermediárias e o método da dose letal $\left(\mathrm{DL}_{50}\right)$ em razões mais altas, especialmente com o inseticida clorpirifós (Milio et al., 1987). Os motivos para essas diferenças não têm sido satisfatoriamente explicadas, mas é sugerido que o método de contato tarsal, onde estima-se o tempo letal fornece razões de resistência mais baixas porque os insetos absorvem inseticida durante todo o período do teste (Cochran, 1995; 1997). Com os métodos de aplicação tópica e contato tarsal (com estimativa do resíduo letal) os insetos recebem uma dose finita de inseticida a qual podem criar um maior diferencial na dose ou concentração necessária para matar os insetos suscetíveis e resistentes e possibilitar as razões de resistência mais altas (Cochran, 1997).

A razão de resistência pode ser afetada tanto pelo método de bioensaio escolhido (Cochran, 1989; Milio et al., 1987; Zhai \& Robinson, 1992) como também pelo estágio de desenvolvimento do inseto (Ladonni, 2001). Por isso, o aparecimento da resistência a inseticidas em populações é geralmente detectado através de uma ou mais técnicas de bioensaio. Falhas no controle podem indicar que os insetos são resistentes ao produto químico que está sendo utilizado, mas essa é uma forma imprecisa de medir a resistência, além do que podem ter outros fatores influenciando, como por exemplo, densidade populacional da praga, qualidade da aplicação, produto (formulação e dose) etc. É necessário que a resistência seja constatada de forma mais precisa, normalmente comparando a suscetibilidade a um produto em populações de campo com a resposta de uma população suscetível de referência a este mesmo produto. Bioensaios em laboratório para medir resistência, podem não necessariamente refletir falhas de controle no campo, devido as diferenças da exposição do inseto ao inseticida (Hemingway et al., 1993b), contudo, eles dão uma indicação do desenvolvimento da resistência nessas populações de campo. 
Os machos de baratas são mais freqüentemente usados para avaliar a toxicidade a inseticidas por causa do seu peso uniforme e fisiologia comparado com as fêmeas e ninfas (Gahlhoff et al., 1999). Matsumura (1985) indicou que a idade e o tamanho são os dois fatores mais importantes influenciando a suscetibilidade aos inseticidas e sugeriu que os efeitos da idade e tamanho estão relacionados aos aumentos de gordura no corpo.

Outra variação no teste é a utilização de doses discriminatórias ou doses diagnósticas (Roush \& Miller, 1986) que pode ser usada com os métodos mencionados acima. Alternativamente, uma dose é freqüentemente usada e as mortalidades das populações suscetível e resistente são comparadas. O termo dose discriminatória é comumente usado quando suficiente evidências genéticas e toxicológicas acumuladas mostram que a dose causa uma diferença na resposta entre os genótipos. Dose diagnóstica é um termo menos rigoroso e é usado quando se quer monitorar a resistência, porém é menos provável que essa dose separe os genótipos (Halliday \& Burnham, 1990). Se a dose ou tempo de exposição, que irá matar todos os indivíduos suscetíveis e nenhum dos resistentes, puder ser estabelecida ou puder pelo menos aproximar a essa situação, a dose discriminatória poderá ser usada para determinar a proporção da população pertencente a cada genótipo. Essa técnica é também usada de forma que os genótipos presentes possam ser separados por uma ou mais doses discriminatórias. Finalmente, pode ser usado em programas de seleção em laboratório, onde os limites das respostas dos indivíduos suscetíveis são bem conhecidos (Roush \& Miller, 1986).

Programas de monitoramento da resistência geralmente envolvem comparações de $\mathrm{DL}_{50}$, DL 99 e coeficientes angulares da equação de regressão obtida através da análise de Probit entre populações de campo e a linhagem suscetível de referência. Isso pode ser um meio adequado de documentar resistência que tenha atingido altos níveis, mas é muito ineficiente para a detecção do desenvolvimento da resistência inicial, ou seja, quando a freqüência inicial da resistência ainda é baixa (Roush \& Miller, 1986).

Tipicamente, os resultados de uma série de concentrações de inseticida são analisados através da análise de Probit para estimar a concentração que mata $50 \%$ da população $\left(\mathrm{CL}_{50}\right)$ e o coeficiente angular da curva concentração-mortalidade. A 
interpretação da $\mathrm{CL}_{50}$ é relativamente correta; e valores elevados geralmente indicam reduzida suscetibilidade. $\mathrm{O}$ coeficiente angular da curva concentração-mortalidade é inversa ao desvio padrão da distribuição fenotípica da tolerância a um inseticida. Dessa forma, maiores coeficientes angulares indicam menor variação fenotípica na resposta da população ao inseticida (Chilcutt \& Tabashnik, 1995).

ffrench-Constant \& Roush (1990) relataram que bioensaios baseados em concentrações discriminatórias ou diagnósticas são mais eficientes do que os valores de dose letal $\left(\mathrm{DL}_{50}\right)$ para detectar baixas freqüências da resistência, podendo detectar o problema ainda no início da evolução da resistência. Porém, bioensaios de concentração diagnóstica baseados na $\mathrm{CL}_{99}$ da linhagem suscetível não proporcionam informações a respeito da magnitude da resistência.

A razão de resistência (RR) é uma medida convencional para avaliar a intensidade da resistência. Variações nessas condições existem dependendo do método de bioensaio (Cochran, 1995). Embora, razões de resistência sejam um importante indicador da resistência, uma questão de grande significado prático é definir a razão de resistência a partir da qual a resistência poderá afetar o desempenho de um produto no campo. A RR de 1,0 indica que a população testada respondeu ao produto químico da mesma forma que a população suscetível (Cochran, 1995).

\subsubsection{Bioensaio de aplicação tópica}

O método da aplicação tópica tem sido uma técnica mais sensível do que o método do contato tarsal (Lee et al., 1996; Milio et al., 1987; Scharf et al., 1995; Scott et al., 1986; Wadleigh et al., 1989; Zhai \& Robinson, 1992; 1996) para a avaliação da resistência em piretróides e organofosforados em B. germanica, pois fornece dados que possibilitam uma melhor discriminação entre os fenótipos (ffrench-Constant \& Roush, 1990). Apesar do intenso uso do método de aplicação tópica, essa técnica não reflete o meio pelo qual as baratas são expostas no campo. Porém, é o único meio de assegurar que doses idênticas do inseticida sejam aplicadas em cada inseto testado. $\mathrm{O}$ método consiste na aplicação de uma gota $(1 \mu \mathrm{l})$ da solução do inseticida técnico diluído em 
acetona, sobre a cutícula da parte ventral do inseto, através de um microaplicador. Contudo, os resultados publicados para inseticidas testados por esse método são extremamente variáveis, devido as diferenças nas condições experimentais, linhagem, sexo e idade das baratas utilizadas pelos diferentes pesquisadores. Quando os procedimentos são padronizados, a técnica pode dar resultados consistentes em testes sucessivos.

Existem alguns detalhes que devem ser observados no uso do método de aplicação tópica, como por exemplo: o microaplicador deve ser corretamente calibrado, pois o tamanho das gotículas e a dose de inseticida aplicado devem ser precisos; o solvente usado deve ser adequado, pois estes podem diferir entre si na proporção de distribuição do inseticida sobre a cutícula e na solubilidade pelas ceras cuticulares, fatores estes que afetam a velocidade de penetração do produto; e além disso, o local de aplicação deve ser o mesmo em todos os insetos. Em baratas sugere-se a aplicação no $1^{\circ}$ esternito abdominal (Atkinson et al., 1995; Lee et al., 1996), na face ventral da barata entre o terceiro par de pernas (Hostetler \& Brenner, 1994) ou na região das coxas posteriores (Milio et al., 1987). A sala onde são efetuados os testes devem apresentar as mesmas condições de temperatura e umidade relativa da sala de criação; a seringa deve ser lavada com acetona antes de se iniciar um novo teste e as doses devem ser aplicadas em ordem crescente; e os resultados são geralmente expressos em $\mu \mathrm{g} /$ inseto ou as vezes $\mathrm{mg} / \mathrm{g}$ para causar 50\% de mortalidade (Cornwell, 1976).

Com a necessidade de se anestesiar as baratas antes da aplicação tópica, Valles \& Koehler (1994) estudaram a influência da anestesia com dióxido de carbono na toxicidade ao clorpirifós em linhagens suscetível e resistente de B. germanica e observaram que a anestesia até um período inferior a 15 min. ou usado em doses múltiplas por curtos períodos ( 15 seg.), não excedendo a quatro 4 vezes, mostrou ser um método aceitável de anestesia de $B$. germanica, pois não afetou a toxicidade do inseticida sobre o inseto. 


\subsubsection{Bioensaio de contato tarsal}

O método de contato tarsal tem sido um dos diversos meios de identificar a resistência a inseticidas em baratas, sendo o mais realístico dos bioensaios pois reflete as condições naturais (Lee et al., 1996), porém não são suficientemente sensíveis para definir a magnitude da resistência porque geralmente proporcionam razões de resistência mais baixas quando comparadas com o método de aplicação tópica (Scharf et al., 1995). Essa técnica de bioensaio para determinar a resistência de baratas foi especificamente desenvolvido e descrito por Keller et al. (1956) para o uso em B. germanica e adaptado pelas Forças Armadas dos EUA em 1959; e posteriormente pela Organização Mundial de Saúde (Organização Mundial de Saúde, 1970) como método de bioensaio padrão (Milio et al., 1987).

Somente uma concentração de inseticida é normalmente utilizada no método de contato tarsal. Esta concentração deve ser cuidadosamente determinada de forma a permitir que o mecanismo de resistência seja expressado. Se concentrações excessivamente altas são usadas seria equivalente a conduzir um teste com uma concentração capaz de matar a maioria dos insetos, e nesse caso poder-se-ia concluir erroneamente que os insetos não sejam resistentes (Cochran, 1997).

O método de contato tarsal envolve contínua exposição de adultos machos de $B$. germanica dentro de frascos de vidro tratados com a solução do inseticida técnico diluído em acetona (Milio et al., 1987). O método de contato tarsal para testar a resistência usa o tempo como variável independente (Cochran, 1989). Nesse método, uma concentração padrão de inseticida é estabelecida empiricamente e os insetos testados são todos expostos à uma superfície tratada com essa concentração previamente determinada. Os insetos permanecem na superfície, com o efeito knock-down sendo anotado periodicamente, até a mortalidade dos insetos após um período de tempo préestabelecido de 24 ou 48 h.

O valor do tempo letal médio obtido neste tipo de bioensaio pode ser referido como $\mathrm{TL}_{50}$. As vantagens deste método de bioensaio são que os insetos são expostos principalmente pelo contato tarsal, como ocorre no campo, pequeno número de baratas é 
necessário para obter resultados adequados, e as baratas continuam absorvendo mais inseticida ao longo do teste. As principais desvantagens são que a atual quantidade de inseticida absorvida é desconhecida, e a medida inicial pode ser mais por efeito knockdown do que por morte, especialmente com piretróides (Cochran, 1995). As diferenças no movimento dos insetos e subsequente acúmulo de inseticida no tarso, através do bioensaio de contato tarsal, pode resultar numa sub ou super-estimativa da resistência, uma vez que a movimentação de uma linhagem no laboratório pode ser menor do que no campo.

Devido à discrepância entre os resultados dos métodos de aplicação tópica e contato tarsal, muitos autores tem estudado a comparação desses bioensaios. Quando as RR são muito altas através de qualquer método, pode haver pequena dúvida de que a resistência seja severa e resultará em fracassos no controle. Em geral, RR maiores do que 20-30 vezes deveriam ser consideradas severas para comprometer a eficácia no campo. Igualmente, quando as $\mathrm{RR}$ são baixas $(\mathrm{RR}<2,0)$, provavelmente a resistência não causará falhas no controle (Cochran, 1995). Valores de RR intermediárias que causem problemas na interpretação e onde os resultados diferem de acordo com o método de bioensaio devem ser analisadas com cautela. O inseticida organofosforado clorpirifós serve como o melhor exemplo nesta situação, pois o método de contato tarsal com estimativa do $\mathrm{TL}_{50}$ consistentemente mostra que a maioria das populações de campo testadas apresentam RR inferiores a 2 vezes e poucas com RR superiores a 5 vezes (Cochran, 1995).

Zhai \& Robinson (1992) avaliaram técnicas de bioensaio para a detecção da resistência de uma população de $B$. germanica a cipermetrina através dos métodos de aplicação tópica e contato tarsal. O método da aplicação tópica foi o mais adequado para avaliar a resistência. A RR obtida por aplicação tópica $\left(\mathrm{DL}_{50}\right)$ foi de 122,6 vezes, enquanto que a RR pelo método de contato tarsal foi de apenas 2,9 vezes, usando a dose diagnóstica de $10 \mu \mathrm{g}$ cipermetrina $/ \mathrm{cm}^{2}$. As diferenças de caminhamento pelo resíduo da cipermetrina entre as linhagens suscetível e resistente influenciaram os valores de $\mathrm{KD}_{50}$. Um bioensaio sem movimentos restritos resultou num maior acúmulo de inseticida no tarso das baratas e subsequente redução na RR baseado no $\mathrm{KD}_{50}$. Ladonni (2001) 
mostrou que o bioensaio de aplicação tópica e o bioensaio de knock-down (semelhante ao bioensaio de contato tarsal mas realizado em placas de Petri) são os mais sensíveis para medir resistência a permetrina em adultos e ninfas (com 2-3 dias de idade) da barata alemã, respectivamente.

Milio et al. (1987) compararam 3 métodos de bioensaio, ou seja, aplicação tópica, contato tarsal com uma única dose e contato tarsal com doses múltiplas, para medir a suscetibilidade de $B$. germanica ao inseticida clorpirifós e encontraram razões de resistência da ordem de 14,3; 7,8 e 2,0 vezes, respectivamente, evidenciando que o método de aplicação tópica pode ser considerado a melhor técnica para se detectar a resistência numa população, principalmente para organofosforados, e o método do contato tarsal com uma única dose, onde estima-se o $\mathrm{TL}_{50}$ mostrou ser o menos eficiente. Quando no método de contato tarsal utilizam-se concentrações relativamente elevadas há possibilidade desse procedimento não detectar baixos níveis de resistência entre as populações de baratas. Cochran (1996) relatou que dificuldades no controle irão ocorrer em $B$. germanica que apresentaram níveis de resistência da ordem de 3 a 5 vezes em bioensaio de contato tarsal. Contudo, tal RR são altamente dependentes da concentração do inseticida usado no bioensaio (Cochran, 1997). Dessa forma parece que esse método tende a dar resultados conservadores quando usados contra organofosforados como clorpirifós e diazinon, mas não com o malation.

Rust \& Reierson (1991) relataram que um valor de RR superior a 10,0 vezes para o clorpirifós, baseada na $\mathrm{DL}_{50}$ representa uma intensidade de resistência crítica a partir da qual o produto pode ser comprometido devido à resistência.

Cochran (1997) encontrou RR superior a 10 vezes em bioensaio de contato tarsal com uma única dose de clorpirifós a $0,5 \mu \mathrm{g} / \mathrm{cm}^{2}$. Milio et al. (1987) usaram uma dose de clorpirifós $\left(5,0 \mu \mathrm{g} / \mathrm{cm}^{2}\right) 10$ vezes superior à usada por Cochran (1997) nos testes com a mesma população e encontraram uma razão da resistência de apenas 2 vezes. Schal (1988) usou uma dose 33 vezes mais alta de clorpirifós $\left(16,5 \mu \mathrm{g} / \mathrm{cm}^{2}\right)$ em relação a Cochran (1997), nessa mesma população de campo e obteve uma razão da resistência de apenas 1,3 vezes. Schal (1988), em bioensaio de contato tarsal testou dose de 0,6 $\mathrm{nl}$ de cipermetrina $/ \mathrm{cm}^{2}$, em 7 linhagens e encontrou razão de resistência superior a 90 vezes e 
com dose de $10 \mathrm{nl} / \mathrm{cm}^{2}$ encontrou RR entre 1,5 e 2,9 vezes. O método de contato tarsal revelou baixa ou nenhuma resistência, contudo resultados de campo ou testes com dose ou concentração letal indicaram a presença de uma considerável resistência (Cochran, 1997).

Wadleigh et al. (1989) trabalharam com resíduos de $4,81 \mu \mathrm{g} / \mathrm{cm}^{2}$ para o clorpirifós e diazinon; $1,92 \mu \mathrm{g} / \mathrm{cm}^{2}$ para a cipermetrina e $0,48 \mu \mathrm{g} / \mathrm{cm}^{2}$ para o fenvalerato e obtiveram uma razão da resistência menor ou igual a 2 vezes através do bioensaio de contato tarsal com dose única a esses inseticidas e através do método de aplicação tópica a razão de resistência foi de 21; 14; 3,2 e 3,1 vezes, respectivamente para o clorpirifós, diazinon, fenvalerato e cipermetrina.

\subsubsection{Casos detectados de resistência de Blattella germanica a inseticidas}

\subsubsection{Resistência a inseticidas organofosforados}

Os inseticidas organofosforados têm sido extensivamente usados no controle de B. germanica e sua popularidade se origina da grande efetividade contra insetos resistentes aos organoclorados. O inseticida clorpirifós, um inseticida do grupo dos organofosforados, tem expressivo uso no controle de baratas no Brasil e nos Estados Unidos. O produto foi primeiramente registrado nos Estados Unidos em 1965 (National Pesticide Telecommunications Network, 1999) e tornaram-se altamente disponíveis no mercado, não havendo evidências de que os insetos poderiam desenvolver altos níveis de resistência a este produto.

O clorpirifós técnico é solúvel em muitos solventes orgânicos e insolúvel em água, podendo ser misturado com agentes de efeito knock-down como as piretrinas e diclorvós, para aumentar a velocidade de ação. Como os outros inseticidas do mesmo grupo, sua ação inseticida é devida à inibição da acetilcolinesterase e subsequente acúmulo de acetilcolina nas terminações nervosas. Isto resulta em uma transmissão excessiva de impulsos nervosos, que causa mortalidade na praga alvo. 
O primeiro caso registrado de resistência de $B$. germanica a um inseticida organofosforado foi em 1961 em Kentucky (EUA) com relação ao diazinon (Georghiou \& Lagunes-Tejeda, 1991). A resistência ao inseticida clorpirifós em B. germanica tem sido largamente documentada (Cochran, 1989; Hemingway et al., 1993a; Milio et al., 1987 e Schal, 1988) e o primeiro caso de resistência de B. germanica a esse inseticida foi detectado pela Organização Mundial de Saúde (OMS) em 1980 no Canadá (Georghiou \& Lagunes-Tejeda, 1991) (Apêndice 1).

Diversas observações têm sido feitas com relação a resistência de B. germanica a organofosforados. Milio et al. (1987) e Rust \& Reierson (1991) usando o método da aplicação tópica mostraram que algumas linhagens coletadas no campo tiveram RR ao clorpirifós da ordem de 10 a 30 vezes, as $\mathrm{DL}_{50}$ atingiram de 1,01 a 7,13 $\mu \mathrm{g}$ clorpirifós por barata. Usando o método do contato tarsal, Cochran (1989) realizou bioensaios em 45 populações de $B$. germanica coletadas no campo com diversos piretróides, dois carbamatos (propoxur e bendiocarb) e quatro organofosforados (diazinon, clorpirifós, acefato e malation) onde mostrou que a maioria das linhagens desses insetos tiveram somente baixo nível de resistência ao diazinon e clorpirifós, e níveis muito altos de resistência aos piretróides. Poucas linhagens mostraram moderada resistência a esses dois inseticidas.

Extensivos estudos de trabalhos japoneses mostraram que o clorpirifós é um dos inseticidas mais tóxicos para B. germanica, Periplaneta americana e P. fuliginosa (Cornwell, 1976). Em aplicação tópica, a $\mathrm{DL}_{95}$ do inseticida clorpirifós foi de 3,3 $\mu \mathrm{g} / \mathrm{g}$ para adultos de B. germanica.

Hemingway et al. (1993a) estudando a resistência de 14 populações de $B$. germanica de 4 países para os inseticidas clorpirifós e propoxur encontraram uma RR para o clorpirifós de 1,4 a 58 vezes e de 8 a 462 vezes baseados na $\mathrm{CL}_{50}$ e $\mathrm{CL}_{90}$, respectivamente; para o propoxur a $\mathrm{RR}$ variou de 1,1 a 4,2 e de 4,4 a 46 vezes baseados na $\mathrm{CL}_{50}$ e $\mathrm{CL}_{90}$, respectivamente. Os coeficientes angulares obtidos através da análise de Probit indicaram que todas as linhagens resistentes foram heterogêneas para a resistência tanto para o clorpirifós quanto para o propoxur. 
Milio et al. (1987) detectaram a existência da resistência ao inseticida clorpirifós em populações de campo de B. germanica ao nível de 14,3 vezes através do método de aplicação tópica. Valles \& Yu (1996) através de bioensaio de aplicação tópica encontraram uma RR de 7 vezes para o clorpirifós.

Cochran (1989) testou a suscetibilidade de 45 populações de campo de $B$. germanica coletadas em diferentes cidades dos Estados Unidos a 12 diferentes inseticidas através do bioensaio de contato tarsal encontrando baixa a moderada resistência aos organofosforados clorpirifós, diazinon e acefato.

Os mecanismos de resistência que têm sido identificados na resistência aos inseticidas organofosforados incluem o aumento da destoxificação metabólica, redução na penetração e insensibilidade do sítio de ação (Siegfried \& Scott, 1992). O mecanismo de resistência mais comum entre os insetos, incluindo baratas, é o aumento da habilidade de indivíduos resistentes em metabolizar o inseticida de maneira rápida para não causar a sua mortalidade. Essa habilidade pode ser geralmente traçada por uma enzima ou sistema de enzimas que estão presentes em altos níveis e/ou enzimas com maior atividade do que as presentes linhagens suscetíveis (Cochran, 1995).

Um importante aspecto da resistência a organofosforados (como por exemplo o clorpirifós) é que níveis de resistência extremamente altos parecem não ocorrer, indiferentemente do método de bioensaio testado. Isso pode ser devido aos mecanismos de resistência envolvidos (Cochran, 1995). A resistência ao clorpirifós é controlada de maneira mais complexa, com 2 ou mais genes envolvidos. Provavelmente isso esteja relacionado com o fato de que a resistência ao clorpirifós aparentemente não atinja níveis extremamente altos, característico de outros inseticidas (Cochran, 1989 e Milio et al., 1987). Mecanismos de resistência identificados para o clorpirifós e propoxur indicam que diferentes formas de enzimas oxidativa e hidrolítica são responsáveis pela resistência (Siegfried \& Scott, 1992). 


\subsubsection{Resistência a inseticidas piretróides}

Os piretróides são mais estáveis e muito mais atrativos devido ao baixo odor e rápida atividade no controle de pragas urbanas (Atkinson et al., 1991). Os piretróides apresentam propriedades desejáveis como e alta toxicidade aos insetos, baixa toxicidade aos mamíferos e alta biodegradabilidade.

A principal característica separando os piretróides dos outros inseticidas é devido a sua efetividade, com rápida ação de choque (knock-down), paralisia e/ou toxicidade para os insetos (mortalidade) utilizando-se baixas doses. O efeito knock-down é definido como a inabilidade do inseto de se locomover de maneira suficientemente coordenada, diferente da paralisia que é a perda de qualquer poder de movimento (Cochran, 1995).

Testes com muitos piretróides, que são geralmente ésteres na qual tanto o grupamento ácido como o álcool podem ter formas isoméricas, têm indicado sua superioridade as piretrinas na mortalidade dos insetos. Existem dois tipos de piretróides na qual diferem na estrutura química e sintomas de exposição: o tipo I, sem o grupo funcional $\alpha$-ciano, inclui a aletrina, tetrametrina, resmetrina, sumitrina, bioresmetrina e permetrina; o tipo II, com o grupo funcional $\alpha$-ciano, inclui a cipermetrina, ciflutrina, cialotrina, deltametrina, esfenvalerato, fluvalinato e fenvalerato (Martinez-Torres et al., 1997). Ambos os tipos de piretróides atuam no sistema nervoso dos insetos, ao nível dos

canais do íon sódio na membrana da célula nervosa. Alguns piretróides do tipo II também afetam a ação de um neurotransmissor o ácido gama-aminobutírico (GABA) (Bloomquist et al., 1997). Algumas formulações de piretróides contém sinergistas, como o butóxido de piperonila altamente utilizado, que restringe a ação das enzimas monoxigenases dependentes do citocromo P-450 que o inseto utiliza para destoxificar o piretróide, permitindo assim, uma maior efetividade do inseticida (Scharf et al., 1998).

A resistência a piretróides também se tornou um sério problema em $B$. germanica (Ebbett \& Cochran, 1997). O primeiro caso registrado de resistência de $B$. germanica a um inseticida piretróide foi na antiga União Soviética em 1979 com relação à tetrametrina (Georghiou \& Lagunes-Tejeda, 1991), representando uma séria perda por 
causa da importância dos piretróides no controle de B. germanica (Cochran, 1994b) (Apêndice 1).

$\mathrm{O}$ inseticida cipermetrina foi um dos primeiros piretróides a ser largamente utilizado para o controle de B. germanica pelos profissionais da área, conseqüentemente sendo um dos primeiros produtos a apresentarem falhas de controle no campo devido ao desenvolvimento da resistência (Zhai \& Robinson, 1996).

Os piretróides tais como a cipermetrina, permetrina, fenvalerato e deltametrina estão entre os mais importantes inseticidas no controle de B. germanica (El-Sayed \& Knowles, 1984). A deltametrina é o princípio ativo mais utilizado e mais ativo entre os inseticidas piretróides (Cochran, 1995). Como inseticida domissanitário no Brasil, a deltametrina é biologicamente o mais potente dos inseticidas piretróides, pois é constituído de um único isômero. Esta característica exclusiva da deltametrina proporciona maior estabilidade da molécula, maior pureza do produto, maior eficiência com doses mais baixas e melhores resultados no controle.

A efetividade dos piretróides para o controle de $B$. germanica tem resultado no uso intensivo desses inseticidas e tem levado ao desenvolvimento da resistência em muitas espécies de insetos. Cochran (1989) relatou que cerca de metade das 45 populações de B. germanica testadas foram altamente resistentes a piretrinas (20 linhagens com $\mathrm{RR}>80$ ) e que somente 8 tiveram resistência a aletrina (7 linhagens com $R R>100$ ). Para o fenvalerato somente uma linhagem teve RR superior a 60. Para a permetrina 3 linhagens apresentaram RR superior a 3,0 e somente linhagem apresentou RR alta $(>100)$, o que poderia comprometer a eficiência de controle com o produto (Cochran, 1989).

Um dos mais importantes mecanismos pela qual os insetos desenvolvem resistência a piretróides é devido à redução na sensibilidade do sítio de ação conferido por um gene conhecido como $k d r$ (resistência por knock-down) (Martinez-Torres et al., 1997). Essa característica confere resistência a certos piretróides e ao DDT e não é afetado pelo uso de sinergistas (Cochran, 1989). Esse tipo de resistência tem sido muito estudado em Musca domestica L., onde diversos variantes do tipo $k d r$ têm sido identificado, incluindo o mais potente fator super $k d r$ que mostra resistência elevada ao 
mais ativo piretróide do tipo II, como a deltametrina (Martinez-Torres et al., 1997). O mecanismo de resistência do tipo $k d r$ foi responsável por resistência ao DDT e resistência cruzada a piretróides (Cochran, 1994b) em linhagens de B. germanica selecionadas com DDT (Siegfried \& Scott, 1992). A forma exata na qual esse mecanismo funciona em baratas é desconhecido, mas em outros insetos tem sido sugerido que modificações nos canais de sódio conferem menor suscetibilidade aos piretróides (Salgado et al. ${ }^{4}$ citado por Cochran, 1995).

A toxicidade de 3 populações de $B$. germanica, através de bioensaio de aplicação tópica foi avaliado por Scott et al. (1990) onde obtiveram RR aos piretróides variando de 4,9 a 19,8 vezes para a cipermetrina; de 0,22 a 27,5 para a deltametrina; de 1,82 a 20 para a fenflutrina; e para as piretrinas de 6,05 a 13,42 vezes. Para o inseticida clorpirifós a RR variou de 1,23 a 4,6 vezes. Uma das populações testadas (Ectiban-R) foi altamente resistente aos 3 piretróides testados (deltametrina $(R R=27,5)$; cipermetrina ( $R R=19,80)$; e fenflutrina $(R R=20)$ ) e piretrinas $(R R=13,42)$, porém suscetível a outros inseticidas (bendiocarb, propoxur, clorpirifós e malation). As outras 2 linhagens apresentaram RR muito altas $(>50)$ aos inseticidas bendiocarb e propoxur.

Lee et al. (1996) coletaram 20 populações de B. germanica de vários locais da Malásia e testaram sua suscetibilidade a diversos inseticidas através de bioensaio de aplicação tópica. Os níveis de resistência foram baixos (2,0 a 7,6 vezes) para o organofosforado (clorpirifós) e baixo a moderado (1,0 a 23 vezes) para os piretróides (cipermetrina e permetrina). Cinco linhagens resistentes a cipermetrina e permetrina foram também resistentes ao DDT, fenotrina e deltametrina (5,9 a 23,6 vezes), o que sugere o envolvimento do mecanismo de resistência através da insensibilidade do alvo de ação desses compostos.

\footnotetext{
${ }^{4}$ SALGADO, V. L.; IRVING, S. N.; MILLER, T. A. Depolarization of motor nerve terminals by pyrethroids in susceptible and kdr-resistant house flies. Pesticide Biochemistry, n.20, p.100-114, 1983.
} 
Atkinson et al. (1991) encontraram níveis de resistência numa população de campo de B. germanica altamente resistente a 10 piretróides (ciflutrina, cialotrina, cipermetrina, fenvalerato, esfenvalerato, fluvalinato, permetrina, resmetrina, sumitrina e tralometrina) através de bioensaios de aplicação tópica encontrando níveis de resistência da ordem de 29,4 (esfenvalerato) a 337,2 (fluvalinato) vezes. Em geral, os piretróides do tipo II foram mais tóxicos do que os do tipo I, mas as RR foram similares para os 2 tipos de piretróides.

Níveis de resistência de 21 a 67 vezes ao piretróide lambdacialotrina foram observados em 13 populações de B. germanica coletadas no campo por Valles (1999) através de bioensaio de aplicação tópica.

Cochran (1991), através de experimentos de seleção por 17 gerações com permetrina ou fenvalerato como agentes seletivos verificou que B. germanica pode desenvolver resistência a todos os inseticidas piretróides comumente disponíveis.

Ladonni (1997) estudaram a suscetibilidade de 5 populações de B. germanica coletadas em 5 apartamentos no Irã aos inseticidas ciflutrina, permetrina, sumitrina e lambdacialotrina através de bioensaio de contato tarsal e concluíram que o desenvolvimento da resistência à permetrina e lambdacialotrina em linhagens dessa espécie de barata resultaram do uso direto de inseticidas nas residências. Comparação do efeito knock-down indicaram que todas as linhagens foram resistentes à sumitrina, com $\mathrm{RR}$ de 3,09 a 7,75 vezes, mas foram suscetíveis à ciflutrina $(\mathrm{RR}<1,5)$. Os testes com permetrina revelaram que 3 das 5 populações testadas foram resistentes $(R R=2,9$ a 3,0 vezes). Outros testes com lambdacialotrina mostraram que 4 de 5 populações testadas foram resistentes e 1 suscetível. A resistência à sumitrina foi provavelmente um resultado da resistência cruzada com outros piretróides.

Huang et al. (1999) estudaram a suscetibilidade de $B$. germanica em 5 cidades da China para os inseticidas deltametrina, cipermetrina, permetrina, propoxur e diclorvós que eram usados regularmente. Através do bioensaio de contato tarsal, os resultados mostraram que $B$. germanica apresentou resistência a todos os inseticidas testados em níveis variados. A suscetibilidade em ordem decrescente foi: deltametrina $>$ propoxur $>$ cipermetrina $>$ permetrina $>$ diclorvós. 
Lin et al. (2000) testaram a resistência de 5 populações de $B$. germanica coletadas no campo a 4 diferentes inseticidas através do bioensaio de contato tarsal na China. Os resultados mostraram que as 5 linhagens coletadas no campo foram suscetíveis ou apresentaram baixa resistência ao clorpirifós e propoxur, e 2 linhagens apresentaram alta resistência a cipermetrina e deltametrina.

A sensibilidade de uma linhagem de campo de $B$. germanica na China à permetrina, deltametrina e cipermetrina foi determinada por bioensaio de aplicação tópica. Os resultados indicaram um alto nível de resistência dessas linhagens aos piretróides, especialmente a permetrina (Zhang et al., 1999). As RR através da $\mathrm{DL}_{50}$ à permetrina, deltametrina e cipermetrina foram de 67,$1 ; 18,1$ e 11,8 ; respectivamente.

A relação entre temperatura e toxicidade dos inseticidas nos insetos tem sido largamente estudada, e a aclimatação da temperatura tem mostrado significativa influência na toxicidade dos inseticidas em baratas. Embora, esse fenômeno tenha sido examinado extensivamente em muitas espécies de insetos, poucos estudos têm comparado as respostas de linhagens suscetíveis e resistentes em diferentes temperaturas. Scott (1987) relatou um coeficiente de toxicidade de temperatura positivo para o piretróide cipermetrina em uma linhagem suscetível de B. germanica. No entanto, uma linhagem resistente com um mecanismo de resistência do tipo $k d r$ exibiu um coeficiente de toxicidade de temperatura negativo para a cipermetrina.

Com o inseticida lambdacialotrina, a linhagem suscetível de B. germanica exibiu um coeficiente de toxicidade de temperatura negativo (Valles et al., 1998). Este inseticida foi quase 3 vezes mais tóxico a $19^{\circ} \mathrm{C}$ do que a $31^{\circ} \mathrm{C}$. Porém, a mortalidade de uma linhagem suscetível a lambdacialotrina não foi afetada pela temperatura. Como resultado, a RR aumentou com o decréscimo da temperatura. A RR foi de 10 vezes a $31^{\circ} \mathrm{C}, 14$ vezes a $26^{\circ} \mathrm{C}$ e 20 vezes a $19^{\circ} \mathrm{C}$.

\subsubsection{Resistência cruzada em Blattella germanica}

A resistência cruzada refere-se aos casos em que um único mecanismo de resistência confere resistência a dois ou mais compostos químicos, produtos estes 
geralmente relacionados (Georghiou, 1983). A resistência pode ocorrer através de modificações fisiológicas, bioquímicas e comportamentais da população (Georghiou, 1972). Em alguns casos, mais de um mecanismo pode estar presente na população. Essa situação é referida como resistência múltipla. A resistência múltipla ocorre quando pelo menos dois diferentes mecanismos de resistência coexistem conferindo resistência a dois ou mais compostos químicos (Georghiou, 1983).

A resistência de $B$. germanica a 2 ou mais inseticidas (através da resistência cruzada ou resistência múltipla) tem sido um dos grandes problemas em programas de manejo dessa praga envolvendo produtos químicos. Muitas populações de B. germanica tem desenvolvido resistência a mais de um composto resultando em maiores dificuldades no seu controle. A resistência cruzada é também um problema potencial que pode limitar a efetividade de alguns novos inseticidas, pois a resistência a um inseticida em B. germanica é freqüentemente acompanhada por resistência cruzada a outros inseticidas as quais a população nunca foi exposta (Cochran, 1987b) o que acaba comprometendo outros produtos até mesmo antes de serem lançados no mercado.

Collins (1973) relatou que B. germanica selecionadas em laboratório pelo inseticida diazinon também apresentaram níveis significativos de resistência ao malation, DDT, propoxur e piretrinas. Além disso, a seleção com propoxur resultou no desenvolvimento de altos níveis de resistência a outros carbamatos, organofosforados, DDT e piretrinas (Collins, 1975). Uma linhagem de laboratório de B. germanica, selecionada com o inseticida diazinon através da aplicação tópica desenvolveu resistência ao dizinon da ordem de 26 vezes e ao malation de 27 vezes e apresentou resistência cruzada a 3 outras principais classes de inseticidas orgânicos representada pelo DDT (>40 vezes), propoxur (18 vezes) e piretrinas (23 vezes) (Collins, 1973).

A ocorrência de resistência cruzada entre piretróides, carbamatos e organofosforados no controle de $B$. germanica não parece se estender para novos compostos como por exemplo a hidrametilona (Valles \& Brenner, 1999); e nem mesmo em populações de B. germanica resistentes aos ciclodienos e fipronil (Bloomquist et al., 1999). Bloomquist et al. (1999) coletaram diversas populações de B. germanica no campo com RR entre 3 e 33 vezes ao inseticida clordane e verificaram que não houve 
resistência cruzada com o inseticida fipronil. Esses novos compostos proporcionam uma alternativa que podem ser integrados com outros piretróides convencionais para programas de manejo da resistência.

Por outro lado, Scott \& Wen (1997) avaliaram a toxicidade do fipronil contra diversas populações resistentes e suscetível de B. germanica e $M$. domestica na presença e ausência do sinergista butóxido de piperonila. O fipronil foi altamente tóxico para a barata alemã baseado na $\mathrm{DL}_{50}$. Uma linhagem resistente de B. germanica $(>17.000$ vezes ao dieldrin) apresentou resistência cruzada de 6,7 a 7,7 vezes ao fipronil em relação a linhagem suscetível. Essa resistência não foi afetada pelo butóxido de piperonila. Os valores da $\mathrm{DL}_{50}$ em 6 outras linhagens de $B$. germanica foram menores do que 2, diferindo da linhagem suscetível. Os níveis relativamente baixos de resistência cruzada detectada pelos autores sugerem que a resistência cruzada pode não ser fator limitante para o uso do fipronil contra a barata alemã e a mosca doméstica.

Valles et al. (1997) observaram que o inseticida fipronil foi efetivo no controle de B. germanica causando mortalidade em linhagens criadas em laboratório quando aplicados em quantidades ínfimas (nanogramas). No entanto, populações coletadas no campo foram significativamente mais resistentes ao fipronil do que a linhagem mais resistente de laboratório. Níveis de resistência significativos (20 a 27 vezes) ao fipronil já foram relatados em linhagens resistentes de mosca doméstica ao dieldrin. Foi sugerido que um mecanismo de resistência pode estar presente em populações de campo de $B$. germanica. Além disso, foi determinado que B. germanica ativa metabolicamente o inseticida fipronil em seu corpo. Mas, a aparente resistência cruzada exibida em populações de campo para o fipronil coloca em risco sua utilidade a longo prazo para o controle de B. germanica.

\subsubsection{Resistência comportamental em Blattella germanica}

A resistência a inseticidas é geralmente considerada como o resultado de mecanismos fisiológicos ou comportamentais, contudo, uma reavaliação de informações disponíveis indicam que as resistências fisiológica e comportamental freqüentemente 
coexistem (Lockwood et al., 1984). A resistência comportamental desenvolvida pelo inseto através da redução na exposição do inseto a compostos tóxicos, permite um inseto de sobreviver num resíduo que seria tóxico e letal ao seu desenvolvimento (Sparks et al., 1989). O mecanismo de resistência comportamental tem sido pouco estudado.

Os métodos para avaliar a resistência a inseticidas são primariamente aplicados para os casos onde a resistência tem bases fisiológicas ou bioquímicas. Considerações a respeito de como a resistência comportamental pode ser avaliada tem sido discutido em várias espécies de insetos (Lockwood et al., 1985; Sparks et al., 1989). Lockwood et al. (1984) relataram a existência de 154 casos de resistência por comportamento, sendo 45 espécies de insetos referentes a 35 diferentes compostos químicos, onde 11,4\% dos casos relatados foram com baratas.

As respostas comportamentais de insetos a inseticidas freqüentemente representam fatores importantes com respeito aos resultados do controle químico, no entanto, a dificuldade da resistência comportamental é de se mostrar a herdabilidade do caráter, uma vez que o efeito do ambiente é muito alto no comportamento dos insetos. Existem poucos dados que provem as bases genéticas da resistência comportamental. Diversos fatores podem contribuir para o aparecimento da resistência comportamental incluindo mobilidade do inseto, escape para áreas não tratadas, e inseticidas que têm alguma ação de irritação ou repelência (Pluthero \& Sing, 1984; Sparks et al., 1989).

A irritabilidade e a repelência são respostas dos inseticidas largamente reconhecidas (Lockwood et al., 1984), mas em B. germanica, uma terceira resposta tem sido relatada. A exposição a inseticidas pode causar a liberação da ooteca pela fêmea prematuramente. Fêmeas de B. germanica expostas ao inseticida malation e diazinon através de bioensaio de contato tarsal apresentaram um aumento na freqüência da liberação da ooteca, ocorrendo naturalmente na linhagem suscetível mas não nas linhagens resistentes ao malation e diazinon (Harmon \& Ross, 1988). 
A repelência é provavelmente o mais importante fator limitando a eficácia de inseticidas usados no controle de B. germanica e de acordo com Burden ${ }^{5}$ (Cochran, 1995), os inseticidas carbamatos, organofosforados e piretróides mostraram diferentes níveis de repelência. O comportamento dos insetos a repelentes químicos é de grande interesse com relação ao controle de $B$. germanica, pois a atividade tóxica de um inseticida pode ser limitada se o inseto alvo evitar contato com o produto (Cochran, 1995).

O comportamento de fuga em B. germanica aos inseticidas pode ser considerado como o resultado de um aprendizado associado, efeito que é reforçado pelo hábito e depende fortemente da repelência do produto aplicado, porque as baratas sobreviventes aprenderam a evitar o inseticida. A porcentagem de mortalidade dessas baratas também depende da toxicidade do inseticida. Se o inseticida é muito tóxico, ou se existe uma grande quantidade dele, nenhuma barata irá sobreviver ao primeiro contato. Após um certo período de tempo, a toxicidade diminui por causa da degradação, e dessa forma, o primeiro contato não causará morte e um comportamento de fuga poderá se desenvolver, a qual aumenta a chance de sobrevivência das baratas individualmente. Observações mostram que a sensibilidade das fêmeas é maior e as chances de sobreviverem depois do aumento do contato com o inseticida (Cochran, 1995).

Sob condições de campo, a habilidade da barata alemã aprender e modificar seu comportamento pode ser um importante meio de sobrevivência dessas populações, pois a habilidade constante de adaptação a trocas de ambiente causada pela intervenção do homem é de grande importância e exige constantes esforços para melhorar os métodos de controle dessa praga (Cochran, 1995).

\footnotetext{
${ }^{5}$ BURDEN, G. S. Repellency of selected insecticides. Pest Control, v.43, n.6, p.16-18, 1975.
} 
O início do comportamento de limpeza (grooming), descritas por Brett \& Ross (1986) e Ross (1992) pelas baratas, após o contato com substâncias químicas estranhas, serve predominantemente para limpar os receptores da antena. Em experimento fechado, com a presença de vapores do propoxur encontrou-se um rápido decréscimo na ação de limpeza de $B$. germanica devido provavelmente à uma contaminação da arena de teste com vapores do produto ou uma fadiga devido à prolongada exposição da antena com substâncias químicas estranhas.

Juntamente com isso ocorreu uma adaptação ou habituação de modo que a atividade da limpeza foi gradualmente cessada (Brett \& Ross, 1986). A intoxicação também pode gerar uma perda da coordenação motora, em que a antena não consegue se desprender da boca e a perna dianteira já não pode mais alcançar e agarrar a antena.

A barata alemã também representa uma espécie de inseto com alto comportamento de plasticidade (uma tentativa de mudança do comportamento para tentar sobreviver) e adaptabilidade. Um excepcional elemento no comportamento de $B$. germanica é a capacidade de agregação, a qual é governado por feromônios que tem um "elemento social" com um efeito no comportamento do inseto individualmente à distribuição espacial da população (Metzger, 1995).

Ross (1997) descreveu duas linhagens de campo de B. germanica com resistência fisiológica ao clorpirifós que foram menos afetadas pela isca com clorpirifós do que a linhagem suscetível. A resistência comportamental à isca de clorpirifós foi aparente nessas linhagens de campo evidenciado pelo decréscimo no consumo da isca através de sucessivas gerações. Subseqüentemente, Ross (1998) determinou que a resistência foi causada pela aversão ao clorpirifós.

\subsubsection{Manejo da resistência de Blattella germanica a inseticidas}

\subsubsection{Principais estratégias de manejo da resistência}

Segundo Georghiou (1983), as estratégias de manejo da resistência podem ser por moderação, cujo objetivo é diminuir o uso de produtos químicos para preservar os 
indivíduos suscetíveis; por saturação, onde se visa minimizar o valor adaptativo dos indivíduos resistentes na presença de pressão de seleção através do uso de sinergistas ou doses elevadas do inseticida; e ainda por ataque múltiplo, através da utilização de mistura de produtos químicos ou em rotação. No entanto, certas dificuldades podem surgir no controle de B. germanica pelo uso de uma ou mais estratégias. O manejo por moderação, provavelmente seja insatisfatório, no caso de $B$. germanica, pelo fato de ser indesejável a presença de baratas vivas pelo ambiente após o tratamento. Uma estratégia que não tem sido extensivamente utilizada é a adição de sinergistas, pois pouco se sabe a respeito dos mecanismos de resistência em $B$. germanica, no entanto, essa estratégia tem mostrado ser útil (Cochran, 1987a). O manejo por ataque múltiplo, talvez o mais utilizado no controle de B. germanica, envolve a utilização de dois ou mais produtos em rotação ou em mistura, no entanto, as estratégias de ataque múltiplo não têm sido testadas experimentalmente contra B. germanica (Cochran, 1995).

De todas as estratégias propostas para se manejar a resistência, a mistura pode ser a que mais cause controvérsias, pois a mistura de produtos químicos, muito utilizado no controle de $B$. germanica tem levado ao desenvolvimento da resistência de pragas para todos os componentes da mistura porque as premissas básicas para o sucesso dessa estratégia são raramente obedecidas. Contudo, o uso da mistura pode ser mais vantajoso do que o uso de um único produto para o controle de populações de insetos (Stone et al., 1988). A recomendação da mistura de produtos químicos é baseada no princípio de que os indivíduos resistentes a um determinado produto serão controlados pelo outro componente da mistura.

Segundo estudos conduzidos por Mani (1985) existem várias condições que devem ser obedecidas, como por exemplo, que a freqüência de resistência para os dois compostos da mistura seja baixa na população; a resistência para cada pesticida seja preferencialmente monogênica e recessiva; os indivíduos duplamente resistentes sejam raros, a utilização de misturas seja iniciada antes que a resistência a um dos compostos tenha sido selecionada; ocorra a presença de refúgio na área não tratada; e que os pesticidas tenham atividade biológica e persistência semelhantes (Mani, 1985; Tabashnik, 1989). 
Numa mistura de dois ou mais inseticidas podem ocorrer os seguintes fenômenos: sinergismo - quando ocorre uma ação superior à somatória das qualidades individuais de cada componente, proporcionando um efetivo controle das pragas simultaneamente, mesmo as que apresentam resistência aos mesmos inseticidas aplicados isoladamente; antagonismo - nesse caso a ação da mistura é inferior ou nula em relação à soma das qualidades individuais de cada ingrediente ativo misturado; adição - em determinadas misturas de inseticidas compatíveis entre si não há a ocorrência de sinergismo e antagonismo, verifica-se apenas uma ação aditiva das qualidades individuais de cada ingrediente ativo, isto é, ambos os produtos agem isoladamente sobre os insetos, de acordo com as suas características químicas. As misturas de inseticidas visam não somente ampliar a eficiência no controle como também tornar os tratamentos mais econômicos, já que, graças ao sinergismo ou potenciação das mesmas, em alguns casos torna-se possível a utilização de doses menores que as normalmente empregadas, em alguns casos, quando se aplica cada inseticida isoladamente (Stone et al., 1988).

Uma desvantagem da mistura é o custo. Análises detalhadas de casos individuais é necessário para determinar o custo do efeito da mistura a curto prazo; misturas aplicadas em proporções não adequadas podem ser muito mais caras do que o uso individual dos produtos (Stone et al., 1988). Proporções adequadas da mistura podem reduzir aplicações e o custo em curto espaço de tempo, principalmente se ocorrer sinergismo.

Byford et al. (1987) trabalhando com mistura de inseticidas no controle de Haematobia irritans (L.) encontraram que a adição de clorpirifós a permetrina resultou numa mistura 2,7 e 2,9 vezes mais tóxica do que a permetrina sozinha; e 19,6 e 5,1 vezes mais tóxica do que o clorpirifós sozinho, nas linhagens suscetível e resistente, respectivamente.

MacDonald et al. (1983) mostraram que o uso de misturas envolvendo um piretróide e um organofosforado pode ser um meio de retardar a resistência a piretróides em Musca domestica L., embora suas análises não tenham avaliado o potencial econômico benéfico de tal retardamento. Pimentel \& Burgess (1985) em estudos de 
laboratório com Musca domestica L. encontraram que na rotação ou mistura de 5 inseticidas houve um pequeno retardamento no desenvolvimento da resistência comparado com o uso seqüencial dos inseticidas isoladamente. Após 30 gerações de seleção por rotação ou mistura, a resistência ao metomil e malation foi mais alta do que após 30 gerações de seleção com o produto isolado.

A rotação de produtos químicos é uma outra estratégia de manejo da resistência dentro do ataque múltiplo. $\mathrm{O}$ uso da rotação é baseada na suposição de que a freqüência de indivíduos resistentes a um pesticida $\underline{\text { A }}$ irá declinar durante a aplicação de um pesticida alternativo $\underline{\mathrm{B}}$, tal declínio é esperado, se na presença do pesticida $\underline{\mathrm{B}}$, indivíduos resistentes ao pesticida $\underline{\mathrm{A}}$ forem menos adaptados do que os indivíduos suscetíveis (Georghiou, 1983) e não haja resistência cruzada entre os produtos usados na rotação. No sistema de rotação, um inseticida é usado por um período de tempo especificado ou número de gerações, e é permitido o uso de inseticidas não relacionados com diferentes mecanismos de ação. Cochran $^{6}$ (Cochran, 1995) tem sugerido esse método para o manejo da resistência de $B$. germanica a piretróides. Uma das premissas da rotação de produtos químicos baseia-se na existência de uma desvantagem adaptativa dos indivíduos resistentes em relação aos suscetíveis.

Dentro do sistema, a rotação de inseticidas que apresentam diferentes mecanismos de ação para manejo da resistência de $B$. germanica a inseticidas novos como fipronil, hidrametilona, reguladores de crescimento de inseto etc, têm sido lançados no mercado.

\subsubsection{Utilização de produtos alternativos no manejo da resistência}

Os programas de manejo da resistência são mais efetivos quando implantados de modo preventivo, ou seja, no início da evolução da resistência (Georghiou, 1983; Roush \& McKenzie, 1987; Tabashnik, 1989).

\footnotetext{
${ }^{6}$ COCHRAN, D. J. Managing resistance in the German cockroach. Pest Control Technology.,v.18, n.2, p.56-57, 1990.
} 
O inseticida fipronil é uma nova classe de inseticida do grupo fenilpirazol a qual foi introduzido nos Estados Unidos em 1996 para uso em saúde animal, no controle de pragas domésticas como a B. germanica, na forma de iscas ou gel, embora também tenha ação por contato. O fipronil age bloqueando os canais de cloro do sistema nervoso central, controlados pelo sistema GABA (ácido gama-aminobutírico), agindo por contato e ingestão (Bloomquist et al., 1997). Seu sítio de ação é distinto dos piretróides, moduladores dos canais de sódio, e dos organofosforados, inibidores da enzima acetilcolinesterase, embora com o mesmo alvo de ação dos ciclodienos, antagonistas do sistema GABA, aumentando assim, o risco de desenvolvimento de resistência cruzada.

Resultados de Kaakeh et al. (1997) relataram que o fipronil é um inseticida altamente efetivo utilizando baixas doses no controle de B. germanica e P. americana. Os autores estudaram a toxicidade tópica do fipronil comparado com o clorpirifós em B. germanica e $P$. americana. Para $72 \mathrm{~h}$ após aplicação tópica o fipronil foi mais tóxico do que o clorpirifós a $B$. germanica $(0,03$ e $0,06 \mu \mathrm{g} / \mathrm{g})$, respectivamente. Para todos os tempos após a aplicação, o fipronil foi significativamente mais tóxico para $P$. americana, $\mathrm{DL}_{50}$ menores, do que o clorpirifós. Para $72 \mathrm{~h}$ após aplicação tópica, a $\mathrm{DL}_{50}$ do fipronil e do clorpirifós foi de 0,02 e $0,16 \mu \mathrm{g} / \mathrm{g}$, respectivamente.

Um outro inseticida alternativo, bastante promissor no controle de B. germanica é o imidacloprid, cujo modo de ação é ser agonista da acetilcolina (Wen \& Scott, 1997). A toxicidade do imidacloprid avaliada por Wen \& Scott (1997) no controle de diversas linhagens resistentes a piretróides, organofosforados e carbamatos de B. germanica mostrou uma ação relativamente rápida. A barata alemã ficou imobilizada por um período de cerca de $72 \mathrm{~h}$ durante a qual algumas baratas recuperaram, não havendo mais nenhuma recuperação após $72 \mathrm{~h}$. O máximo efeito foi visto com 2 a $4 \mathrm{~h}$ após o tratamento, em bioensaio de aplicação tópica. A moderada toxicidade do inseticida imidacloprid a linhagens suscetíveis de B. germanica, $\mathrm{DL}_{50}$ de 270 a $410 \mathrm{ng} /$ barata avaliado com $72 \mathrm{~h}$, indica que esse material é similar em toxicidade aos inseticidas comumente usados como por exemplo, carbamatos e organofosforados, mas é substancialmente menos tóxico do que a maioria dos piretróides (Wen \& Scott, 1997). 
A utilização desses novos produtos químicos na forma de iscas tem sido uma outra opção para o manejo da resistência em B. germanica. O uso de iscas resulta em menor contaminação do meio ambiente e maior facilidade de aplicação em relação a pulverização. Gahlhoff et al. (1999) com 5 formulações de iscas comercialmente disponíveis avaliaram a mortalidade direta de $1^{\circ}$ e $2^{\circ}$ instar de B. germanica e mortalidade secundária de machos, através do canibalismo de ninfas alimentadas por iscas. Iscas de clorpirifós e fipronil causaram mortalidade em ninfas de $1^{\mathrm{o}}$ e $2^{\mathrm{o}}$ instar significativamente mais rápido do que a hidrametilona, ácido bórico ou abamectina. Mortalidade secundária foi observada para todas as iscas testadas e os adultos que consumiram ninfas tratadas tiveram significativamente maior mortalidade do que os que se alimentaram de ninfas não tratadas.

$\mathrm{O}$ efeito de 3 ingredientes ativos em iscas contendo glicose foram estudados por Silverman \& Liang (1999) onde encontraram que a isca à base de fipronil foi 17 e 29 vezes mais tóxica do que as iscas de hidrametilona e clorpirifós, respectivamente. $\mathrm{O}$ fipronil é mais tóxico do que o clorpirifós e a hidrametilona, e as iscas com fipronil não são repelentes promovendo alta mortalidade nas baratas, pois é altamente tóxica (Scott \& Wen, 1997).

Durier \& Rivault (2000) observaram que as baratas morreram mais rapidamente após ingestão de iscas à base de fipronil do que abamectina ou hidrametilona, devido as baratas sobreviverem mais tempo com a ingestão da isca de hidrametilona do que a de fipronil. O resíduo de hidrametilona parece ser muito menos eficiente por contato do que por ingestão.

\subsubsection{Manejo integrado de pragas}

Muitas estratégias de manejo da resistência têm sido identificadas nos últimos 40 anos, mas poucas tem sido colocadas em prática, especialmente na área urbana. $\mathrm{O}$ único método largamente difundido para evitar a resistência tem sido a redução do uso de pesticidas, o que tem sido a principal motivação para o desenvolvimento de programas de manejo integrado de pragas (MIP). Os métodos tradicionais de controle 
tendem a ignorar as causas do problema, aplicando inseticidas como medida corretiva sem se preocupar em modificar as condições que propiciam a entrada e o estabelecimento das populações de B. germanica.

A necessidade de detectar os insetos antes que ocorram danos econômicos é fundamental para a estratégia do MIP, agindo de forma preventiva e com condições sanitárias adequadas. O MIP embora relativamente novo em nosso país, principalmente na área urbana, tem sido adotado pela National Pest Control Association (NPCA) dos Estados Unidos desde 1974. Sabe-se que nenhum método pode ser completamente eficiente quando utilizado isoladamente, dessa forma o MIP baseia-se no uso de vários métodos de forma complementar e integrada, com ênfase na utilização de medidas preventivas.

O controle químico, ainda como importante tática do MIP, na verdade é uma medida que não resolverá totalmente o problema, promovendo apenas a eliminação temporária da praga. Esta ressurgirá em pouco tempo, tendo que ser tratada novamente. A filosofia do controle integrado é a de reduzir a população de pragas a níveis toleráveis, ao invés de erradicá-las. Tal filosofia, entretanto, pode ser incompatível no caso de baratas, com a expectativa da maioria da população ser a favor da erradicação.

A modificação física do ambiente onde a barata vive é o procedimento mais importante para o seu controle. Métodos de inspeção, amostragem, ordem e limpeza; e métodos mecânicos; físicos; químicos e biológicos devem ser integrados de forma a conseguir uma máxima eficiência na supressão e prevenção de pragas, isto porém, dentro de uma relação custo/benefício eficiente, dando-se prioridade à proteção da saúde humana e do ambiente. Qualquer programa de controle terá sucesso a longo prazo se as infestações nas imediações da área a ser tratada forem diminuídas ou mesmo eliminadas. Programas educacionais são particularmente importantes onde condições anti-higiênicas impedem esforços no controle de pragas (Schal \& Hamilton, 1990).

Schal (1988) verificou uma relação positiva entre redução do número de baratas e o aumento da sanitização em locais onde a população de $B$. germanica foi reduzida a níveis aceitáveis, os maiores cuidados das condições sanitárias aumentou a eficácia dos tratamentos com inseticidas, enfatizando a necessidade do uso de um controle integrado. 
Na prática o que realmente acontece é a aplicação intensa de inseticidas porque os controladores de pragas freqüentemente aumentam a dose ou a freqüência de aplicação dos inseticidas usados, dentro de limites legais para combater casos de resistência.

Apesar de rigorosas medidas de sanitização e de procedimentos de manejo não químicos, é imprescindível a utilização de inseticidas no controle de B. germanica. $\mathrm{O}$ controle de $B$. germanica é baseado principalmente na aplicação de inseticidas residuais em áreas infestadas, mas para isso deve existir um consenso de qual estratégia de manejo seja melhor na utilização do inseticida.

O sucesso num programa de manejo da resistência a inseticidas em $B$. germanica pode depender da detecção de baixos a moderados níveis de resistência em diferentes classes de inseticida. De um modo geral, poucos trabalhos experimentais que respondam qual a melhor forma para o uso do inseticida foram realizados até o momento. Evidências mostram que a melhor estratégia recomendada numa dada situação depende da genética da resistência para um particular inseticida e uma determinada população da praga. Considerações tais como custo, segurança, e efeito em organismo não alvo, não são fatores geralmente considerados nos modelos ou nos experimentos (Tabashnik, 1989). O grande desafio dentro de um programa de MIP está na implementação das diferentes estratégias de manejo da resistência a pesticidas em diversos ecossistemas (Roush, 1989). 


\title{
3 MONITORAMENTO DA SUSCETIBILIDADE DE POPULAÇÕES DE Blattella germanica (L., 1767) (Dictyoptera: Blattellidae) A INSETICIDAS
}

\author{
Autor: Eloisa Salmeron \\ Orientador: Prof. Dr. Celso Omoto
}

\section{Resumo}

O objetivo deste trabalho foi o de avaliar a suscetibilidade de populações de Blattella germanica (L.) aos inseticidas deltametrina e clorpirifós, e também ao novo inseticida fipronil. Para tanto, técnicas de bioensaio de aplicação tópica e de contato tarsal foram comparadas para a deteç̧ão da resistência. O bioensaio de aplicação tópica possibilitou uma melhor discriminação entre a linhagem suscetível e as populações de campo de B. germanica testadas. Para deltametrina, as razões de resistência (RR) encontradas foram de 10,32;14,08 e 100,80 vezes com o bioensaio de aplicação tópica e de 2,21; 2,25 e 1,98 vezes com o bioensaio de contato tarsal para as populações RJ-1, RJ-2 e SP-1, respectivamente. Para clorpirifós, as RR foram de 4,98; 6,62 e 30,06 vezes com o bioensaio de aplicação tópica e de 1,35; 1,47 e 1,70 vezes com o bioensaio de contato tarsal, respectivamente. Resultados do monitoramento da suscetibilidade de $B$. germanica a inseticidas, por meio de bioensaio de aplicação tópica, evidenciaram a presença de variabilidade genética que confere resistência a deltametrina, clorpirifós e fipronil em populações coletadas em alguns estabelecimentos comerciais dos Estados de São Paulo e Rio de Janeiro. As RR variaram de 10,32 a 100,80 vezes para a deltametrina, de 4,98 a 30,06 para o clorpirifós e de 2,00 a 6,36 vezes para o fipronil. 


\title{
MONITORING THE SUSCEPTIBILITY OF Blattella germanica (L., 1767) (Dictyoptera: Blattellidae) POPULATIONS TO INSECTICIDES
}

\author{
Author: Eloisa Salmeron \\ Adviser: Prof. Dr. Celso Omoto
}

\section{Summary}

This work aimed to evaluate the susceptibility of Blattella germanica (L.) populations to conventional insecticides deltamethrin and chlorpyrifos, and also to a recently registered insecticide fipronil. For this purpose, topical and tarsal-contact bioassays were compared to detect resistance. Topical contact bioassay gave better discrimination between the susceptible strain and field-collected populations of $B$. germanica. For deltamethrin, the resistance ratios (RR) were 10.32; 14.08 and 100.80fold with topical bioassay and $2.21 ; 2.25$ and 1.98-fold with tarsal-contact one to RJ-1, RJ-2 and SP-1 populations, respectively. For chlorpyrifos, the RR were 4.98; 6.62 and 30.06-fold with topical bioassay and 1.35; 1.47 and 1.70-fold with tarsal-contact one, respectively. Results from a survey of $B$. germanica susceptibility to insecticides, with the use of topical bioassay, revealed the presence of genetic variability that confers resistance to deltamethrin, chlorpyrifos and fipronil in field-collected populations of $B$. germanica from the States of São Paulo and Rio de Janeiro. The RR varied from 10.32 to 105 -fold to deltamethrin, 4.98 to 30.06 -fold to chlorpyrifos and 2.00 to 6.36 -fold to fipronil. 


\subsection{Introdução}

A barata alemã, Blattella germanica (L., 1767) (Dictyoptera: Blattellidae) é a espécie de barata mais freqüente em nosso convívio. Essa espécie é cosmopolita e suas infestações variam dependendo da posição geográfica e das condições sócioeconômicas. Sua alta adaptabilidade é a principal razão de serem dificilmente controladas, e mesmo após milhões de anos de co-evolução, a barata alemã ainda representa um grande desafio para o homem (Cochran, 1999).

A aplicação de inseticidas no controle de B. germanica tem se tornado cada vez mais intensa e o perigo associado com essa prática exige que constantes inovações sejam implantadas, fazendo com que a procura por novos inseticidas e métodos de aplicação sejam um processo contínuo dependente de muitos fatores, incluindo a habilidade dos insetos de desenvolver resistência a inseticidas. Os inseticidas organofosforados e piretróides têm sido bastante usados no controle de B. germanica, e sendo assim a resistência ao organofosforado clorpirifós, por exemplo, tem sido largamente difundida (Milio et al., 1987; Rust \& Reierson, 1991), assim como a resistência aos piretróides permetrina, cipermetrina e lambdacialotrina (Hemingway et al., 1993b; Valles, 1998).

Uma das principais etapas dentro de um programa de manejo da resistência de pragas a pesticidas é definir uma técnica de bioensaio que permita uma maior separação entre as linhagens suscetível e resistente da praga (Dennehy et al., 1983; ffrenchConstant \& Roush, 1990). As duas técnicas de bioensaio mais comumente usadas para detectar a resistência a inseticidas em $B$. germanica têm sido os métodos de aplicação tópica e de contato tarsal. O método de aplicação tópica tem sido usado para monitorar resistência em numerosas espécies de insetos (ffrench-Constant \& Roush, 1990), enquanto que o método de contato tarsal (Keller et al., 1956) foi especificamente desenvolvido para o uso em B. germanica, sendo este mais realístico do que o método de aplicação tópica porque os insetos entram em contato com o resíduo de inseticida. As intensidades de resistência a inseticidas reportadas para $B$. germanica têm variado de acordo com o método de bioensaio utilizado; e em geral, a aplicação tópica tem 
possibilitado uma melhor detecção da resistência (Cochran, 1989; Milio et al., 1987; Rust \& Reierson, 1991).

Apesar de inúmeros trabalhos de monitoramento da resistência de $B$. germanica a vários inseticidas no âmbito mundial, pesquisas nesta área ainda são bastante carentes no Brasil. Sendo assim, o objetivo deste trabalho foi o de avaliar a suscetibilidade de populações de $B$. germanica aos inseticidas deltametrina e clorpirifós, e também ao novo inseticida fipronil. Para tanto, técnicas de bioensaio de aplicação tópica e de contato tarsal foram avaliadas para a detecção da resistência. Posteriormente, um monitoramento da suscetibilidade de $B$. germanica a esses inseticidas foi realizado a partir de populações coletadas em alguns estabelecimentos comerciais dos Estados de São Paulo e Rio de Janeiro.

\subsection{Material e Métodos}

\subsubsection{Coleta de populações de Blattella germanica}

Populações de B. germanica foram coletadas em estabelecimentos comerciais nas cidades de Piracicaba-SP, São Paulo-SP e Rio de Janeiro-RJ (Quadro 1), sendo posteriormente mantidas em criação no laboratório de Resistência de Artrópodes a Pesticidas no Setor de Entomologia do Departamento de Entomologia, Fitopatologia e Zoologia Agrícola da Escola Superior de Agricultura “Luiz de Queiroz" (ESALQ/USP) em Piracicaba-SP.

As baratas foram coletadas através de armadilhas confeccionadas com frascos de vidro $(500 \mathrm{ml})$ revestidos com papel toalha e contendo uma isca à base de pão embebido em cerveja (Cornwell, 1976). Foram coletados pelo menos 50 indivíduos em vários estágios de desenvolvimento sem considerar sexo ou idade para o estabelecimento de uma determinada população no laboratório. A linhagem suscetível (denominada de SUS) foi obtida da Bioagri Laboratórios Ltda., Piracicaba-SP, onde a população era mantida em laboratório por mais de dez anos sem nunca ter recebido qualquer tratamento com inseticida. 


\subsubsection{Criação de Blattella germanica em laboratório}

A criação de Blattella germanica em laboratório foi realizada segundo procedimentos reportados por Cornwell (1968). Foram utilizados recipientes de vidro medindo $55 \times 25 \times 30 \mathrm{~cm}$, cobertos com uma tela de voil e vaselina na borda superior interna. Essa técnica permitiu que o recipiente pudesse ser facilmente limpo e que tivesse alimento, água e abrigo em condições de temperatura e umidade relativa controladas, com um mínimo de mão-de-obra. Como abrigo para as baratas foram utilizados vários cartuchos de papelão corrugado $(3 \mathrm{~cm}$ de diâmetro por $20 \mathrm{~cm}$ de comprimento presos com fita crepe) sobrepostos. A dieta das baratas consistiu de ração para cachorro, gelatina e leite em pó, além de um fornecimento ininterrupto de água através de bebedouros plásticos. A criação foi mantida em uma sala regulada à temperatura de $28 \pm 1^{\circ} \mathrm{C}$, umidade relativa de $55 \pm 5 \%$ e fotofase de $12 \mathrm{~h}$ (Lee et al., 1996).

\subsubsection{Técnicas de bioensaio para detecção da resistência de Blattella germanica a inseticidas}

Os bioensaios foram realizados com os inseticidas deltametrina $(98,5 \%$ de pureza, Aventis Environmental Science); clorpirifós (97\% de pureza, DowAgrosciences Industrial Ltda.) e fipronil ( $89 \%$ de pureza, Aventis Environmental Science). Inicialmente foram testadas a linhagem suscetível (SUS) e 3 populações de campo (RJ1, RJ-2 e SP-1) coletadas em estabelecimentos comerciais cujo controle já se mostrava difícil após contínuo e intenso uso de inseticidas nessas localidades. Todos os testes foram realizados somente com machos de B. germanica. 


\begin{tabular}{|c|c|c|c|}
\hline População & Local de coleta & Cidade & Data de coleta \\
\hline SUS & Laboratório & Piracicaba-SP & $\ldots$ \\
\hline PIR - 1 & Restaurante & \multirow{2}{*}{ Piracicaba-SP } & Agosto/98 \\
\hline PIR - 2 & Bar & & Maio/99 \\
\hline RJ - 1 & $\begin{array}{l}\text { Refeitório } \\
\text { Industrial }\end{array}$ & \multirow{3}{*}{ Rio de Janeiro-RJ } & Abril/93 \\
\hline $\mathrm{RJ}-2$ & Supermercado & & Outubro/96 \\
\hline $\mathrm{RJ}-3$ & Restaurante & & Fevereiro/00 \\
\hline SP - 1 & Refeitório industrial & \multirow{4}{*}{ São Paulo-SP } & Setembro/97 \\
\hline SP - 2 & Residência & & Janeiro/98 \\
\hline SP - 3 & $\begin{array}{l}\text { Porão de edifício } \\
\text { residencial }\end{array}$ & & Janeiro/99 \\
\hline $\mathrm{SP}-4$ & Empório & & Outubro/99 \\
\hline
\end{tabular}

Quadro 1 - Local e data de coleta das populações de Blattella germanica. 


\subsubsection{Bioensaio de aplicação tópica}

No bioensaio de aplicação tópica, os inseticidas deltametrina, clorpirifós e fipronil foram aplicados na forma de produto técnico diluído em acetona, testando-se de 6 a 8 concentrações, espaçadas em escala logarítmica, que proporcionaram mortalidades entre 5 e 99\% para cada inseticida e população.

As baratas foram inicialmente separadas e distribuídas em recipientes plásticos de $500 \mathrm{ml}$ previamente etiquetados. Para cada concentração do inseticida foram testados cerca de 80 indivíduos ( 8 grupos de 10 baratas por recipiente). Após a separação das baratas, estas foram anestesiadas com $\mathrm{CO}_{2}(20 \mathrm{~s}$ a 10L/min.) (Valles \& Koehler, 1994) e submetidas à aplicação de $1 \mu 1$ da solução do inseticida por barata através de uma microseringa de vidro de $1 \mathrm{ml}$ acoplada a um microaplicador automático (modelo Arnold LV6 da Burkard Manufacturing Co. Ltda.). A gotícula foi aplicada na face ventral no $1^{\circ}$ segmento abdominal (Lee et al., 1996; Valles \& Yu, 1996). No tratamento controle as aplicações foram feitas utilizando-se apenas a acetona e testando-se apenas a metade do número de insetos utilizados nos tratamentos. Após a aplicação, as baratas foram transferidas em um recipiente contendo algodão embebido em água e alimento (ração para cachorro). Em seguida, os recipientes foram fechados com tampas plásticas contendo orifícios para a circulação de ar. Os recipientes foram acondicionados em uma câmara climatizada regulada à temperatura de $28 \pm 1^{\circ} \mathrm{C}$, umidade relativa de $55 \pm 5 \%$ e fotofase de $12 \mathrm{~h}$ (Lee et al., 1996). A avaliação da mortalidade foi realizada com 24, 48 e $72 \mathrm{~h}$ após a aplicação do inseticida, adotando-se como critério de resposta as baratas incapazes de se locomoverem normalmente, mostrando evidências de paralisia ou tombamento.

Os dados de mortalidade para cada tempo de avaliação foram submetidos à análise de Probit, através do programa estatístico POLO-PC (LeOra Software, 1987) para a estimativa da $\mathrm{CL}_{50}$. Posteriormente o valor obtido para a $\mathrm{CL}_{50}$ foi dividido pelo peso médio das baratas (mg) da população correspondente, de forma a expressar os dados em termos de $\mathrm{DL}_{50}(\mu \mathrm{g} \mathrm{ia} / \mathrm{mg})$. A razão de resistência foi obtida através do quociente entre a $\mathrm{DL}_{50}$ da população em estudo pela $\mathrm{DL}_{50}$ da linhagem SUS. 


\subsubsection{Bioensaio de contato tarsal}

Para avaliar a suscetibilidade das populações de $B$. germanica a deltametrina e clorpirifós através do bioensaio de contato tarsal (Organização Mundial de Saúde, 1970), frascos de vidro de $500 \mathrm{ml}\left(294,52 \mathrm{~cm}^{2}\right.$ de superfície interna) foram previamente tratados com 2,5ml da solução de inseticida (produto técnico diluído em acetona). Os frascos foram tratados com $200 \mu \mathrm{g}$ deltametrina/ml de acetona $(1,70 \mu \mathrm{g}$ deltametrina $\left./ \mathrm{cm}^{2}\right)$ e $1000 \mu \mathrm{g}$ clorpirifós $/ \mathrm{ml}$ de acetona $\left(8,49 \mu \mathrm{g}\right.$ clorpirifós $\left./ \mathrm{cm}^{2}\right)$, e em seguida foram colocados numa capela para exaustão de gases até a manhã do dia seguinte para a evaporação do solvente. Para o tratamento controle, os frascos foram tratados apenas com a acetona. Posteriormente, 10 baratas foram infestadas por frasco tratado. Após a infestação, foi avaliado o efeito de choque (knock-down) para a deltametrina ou insetos moribundos para o clorpirifós, em intervalos de tempo entre 3 e 560 minutos. Posteriormente, a mortalidade foi avaliada com 12 e $24 \mathrm{~h}$ após a infestação. Após a permanência dos insetos no resíduo por $24 \mathrm{~h}$, tanto para a deltametrina como para o clorpirifós, os sobreviventes foram retirados e colocados em recipientes plásticos com tampa (10 baratas por recipiente) contendo algodão embebido em água e alimento (ração para cachorro). A mortalidade foi avaliada com 48 e $72 \mathrm{~h}$ após a infestação. Os indivíduos incapazes de se locomoverem normalmente mostrando evidências de paralisia ou tombamento foram considerados mortos.

Os testes foram conduzidos à temperatura de $28 \pm 1{ }^{\circ} \mathrm{C}$, umidade relativa de $55 \pm 5 \%$ e fotofase de $12 \mathrm{~h}$. Os dados de resposta foram submetidos à análise de Probit, através do programa estatístico POLO-PC (LeOra Software, 1987) para estimativa do tempo de knock-down $\left(\mathrm{KD}_{50}\right)$ para a deltametrina e tempo letal $\left(\mathrm{TL}_{50}\right)$ para o clorpirifós.

Posteriormente foi calculada a razão de resistência (quociente da $\mathrm{KD}_{50}$ ou $\mathrm{TL}_{50}$ da população em estudo pela $\mathrm{KD}_{50}$ ou $\mathrm{TL}_{50}$ da linhagem suscetível). 


\subsubsection{Monitoramento da suscetibilidade de populações de Blattella germanica a deltametrina, clorpirifós e fipronil}

Um monitoramento da suscetibilidade de $B$. germanica aos inseticidas deltametrina e clorpirifós foi realizado em 9 populações de campo (PIR-1, PIR-2, SP-1, SP-2, SP-3, SP-4, RJ-1, RJ-2 e RJ-3) e em 3 populações para o inseticida fipronil (RJ-1, RJ-2 e RJ-3) coletadas em diversos estabelecimentos comerciais (Quadro 1). O método de bioensaio utilizado foi o de aplicação tópica avaliado com $48 \mathrm{~h}$, pois mostrou ser o melhor método para detecção da resistência de $B$. germanica a inseticidas.

Os dados de resposta foram submetidos à análise de Probit, através do programa estatístico POLO-PC (LeOra Software, 1987) para estimativa da $\mathrm{CL}_{50}$, e em seguida transformados em $\mathrm{DL}_{50}$ e cálculo da razão de resistência (quociente da $\mathrm{DL}_{50}$ da população em estudo pela $\mathrm{DL}_{50}$ da linhagem SUS).

\subsection{Resultados e Discussão}

\subsubsection{Técnicas de bioensaio para detecção da resistência de Blattella germanica a inseticidas}

\subsubsection{Bioensaio de aplicação tópica}

A partir dos resultados de concentração-mortalidade da linhagem SUS e das populações RJ-1, RJ-2 e SP-1 de B. germanica avaliadas com 24, 48 e 72 h após aplicação tópica com o inseticida deltametrina, foram observados que o melhor tempo para avaliação das suscetibilidades das populações testadas foi com $48 \mathrm{~h}$. (Figura $1 \mathrm{e}$ Tabela 1). Um aumento na resposta foi observado com o tempo de avaliação, porém optou-se pela avaliação com $48 \mathrm{~h}$, por proporcionar resultados mais consistentes (menor intervalo de confiança para os parâmetros estimados) e respostas mais rápidas do que com 72 h (ffrench-Constant \& Roush, 1990). Em alguns casos não foi possível estimar o intervalo de confiança (IC) da $\mathrm{DL}_{50}$, pois os dados não se adequaram ao modelo de 
Probit, como por exemplo na avaliação com $24 \mathrm{~h}$ para a população SP-1 para a deltametrina. Resultados de literatura são muito discrepantes em relação ao tempo de avaliação dos bioensaios com esses inseticidas. Alguns autores relataram a avaliação com 24 h após a aplicação (Milio et al., 1987; Valles \& Yu, 1996), outros com 48 h (Hostetler \& Brenner, 1994; Lee et al., 1996) ou mesmo com 72 h (Scharf et al., 1995).

Foram observadas reduções significativas na suscetibilidade a deltametrina em populações de campo de $B$. germanica, quando comparadas com a suscetibilidade da linhagem SUS (Tabela 1). Para a avaliação com 48 h, as razões de resistência (RR) calculadas para as populações RJ-1, RJ-2 e SP-1 foram de 10,32; 14,08 e 100,80 vezes; respectivamente. Os coeficientes angulares da curva de regressão obtidos pela análise de Probit em populações de campo testadas com o inseticida deltametrina foram sempre menores do que o coeficiente angular da linhagem SUS (Tabela 1). Segundo Hoskins \& Gordon (1956), uma interpretação biológica do coeficiente angular está relacionada à homogeneidade de uma determinada população, isto é, quanto maior o coeficiente angular, maior a homogeneidade dessa população. Portanto, há indícios da presença de indivíduos resistentes em freqüências relativamente altas nas populações de $B$. germanica testadas no presente trabalho, principalmente na população SP-1. 
Linhagem SUS

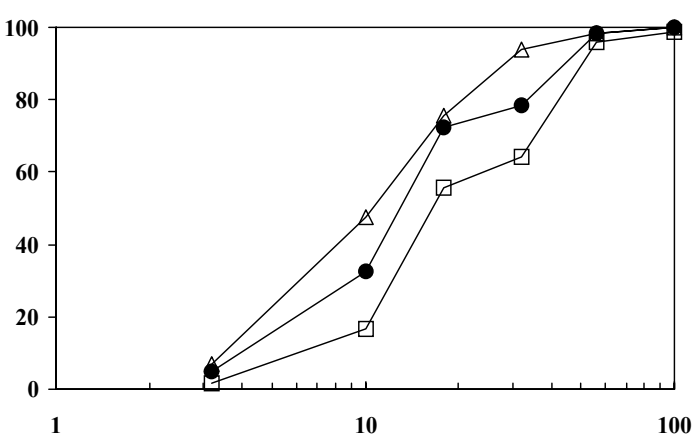

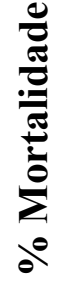

População RJ-2

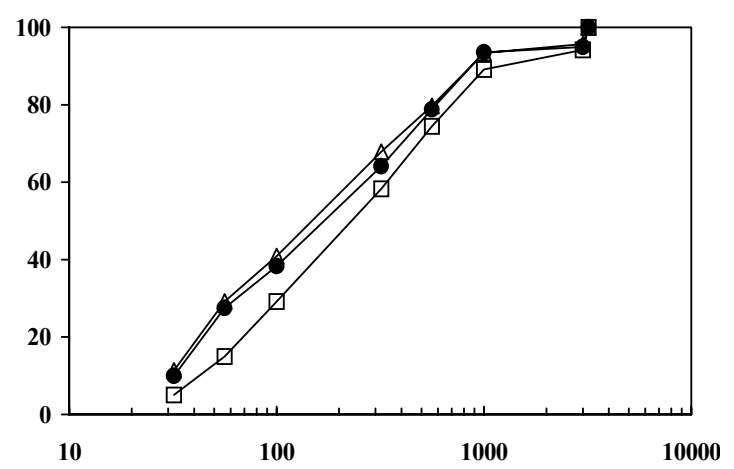

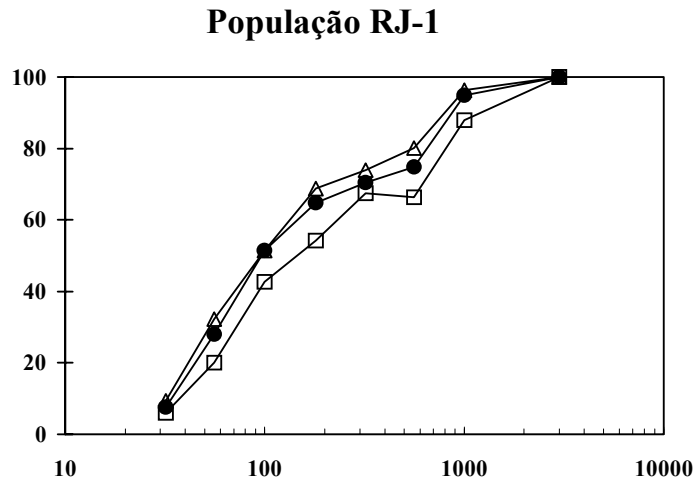

População SP-1

População RJ-1

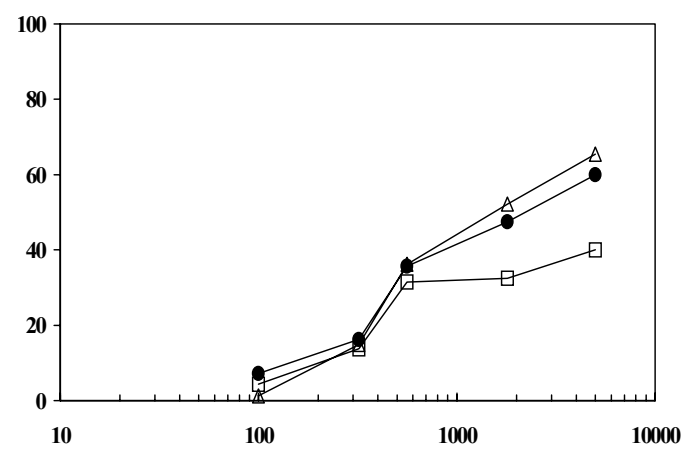

$\mu \mathrm{g}$ deltametrina/ml de acetona

Figura 1 - Curvas de concentração-mortalidade de Blattella germanica avaliada com $24(\square), 48(\bullet)$ e $72(\Delta)$ h após aplicação tópica com o inseticida deltametrina para a linhagem SUS e populações RJ-1, RJ-2 e SP-1. 
Tabela 1. Respostas de dose-mortalidade da linhagem suscetível (SUS) e das populações RJ-1, RJ-2 e SP-1 de Blattella germanica avaliadas com 24, 48 e 72h após aplicação tópica com o inseticida deltametrina.

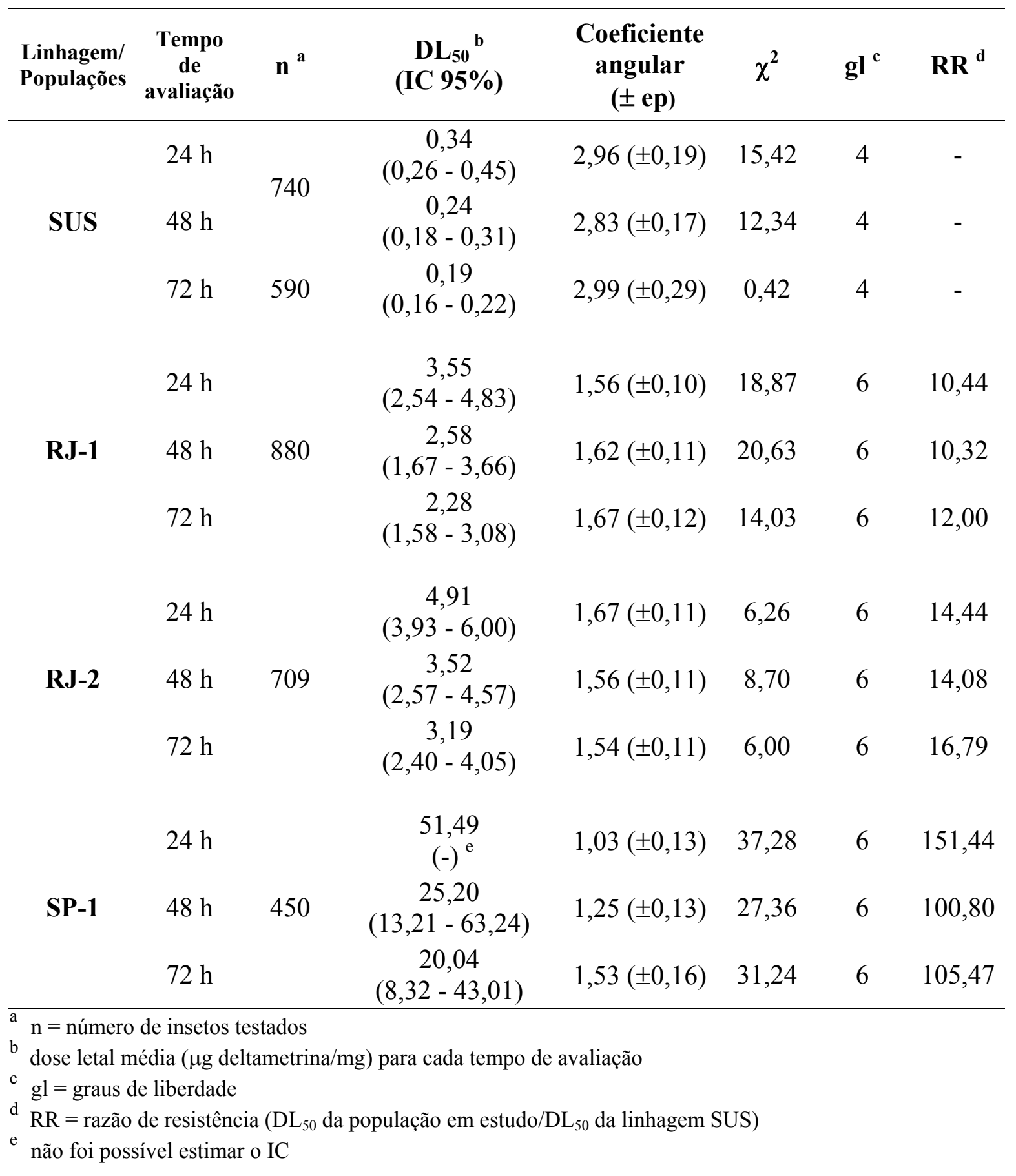


Para o inseticida clorpirifós, foi verificado também que o melhor tempo de avaliação foi com $48 \mathrm{~h}$ após a aplicação tópica (Figura 2 e Tabela 2), embora as diferenças não sejam significativas entre os tempos de avaliação. Em alguns casos não foi possível estimar o IC, pois os dados não se adequaram ao modelo de Probit, como por exemplo na avaliação com $24 \mathrm{~h}$ na linhagem SUS para o clorpirifós.

Os resultados da análise de Probit para o clorpirifós (Tabela 2) mostraram também uma redução significativa na suscetibilidade a esse inseticida em populações de campo de B. germanica. As razões de resistência (RR) calculadas para as populações RJ-1, RJ-2 e SP-1 foram de 4,98; 6,62 e 30,06 vezes; respectivamente. Ao contrário dos resultados com deltametrina, os coeficientes angulares das populações de campo testadas com o inseticida clorpirifós foram bastante próximos ao coeficiente angular da linhagem SUS. 
Linhagem SUS

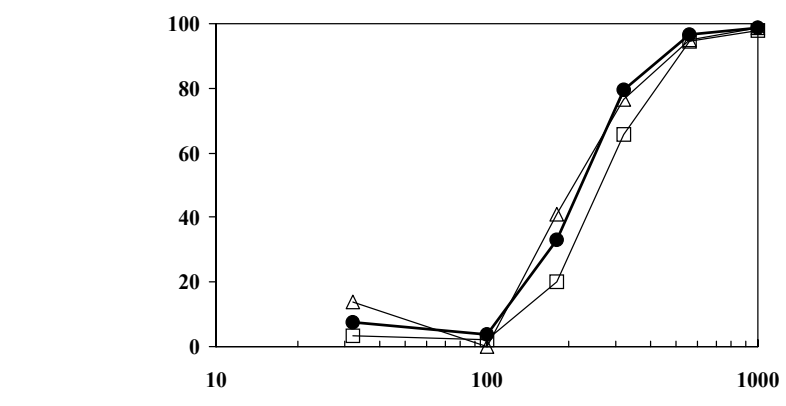

$\sum_{e^{0}}^{\frac{0}{0}}$

População RJ-2

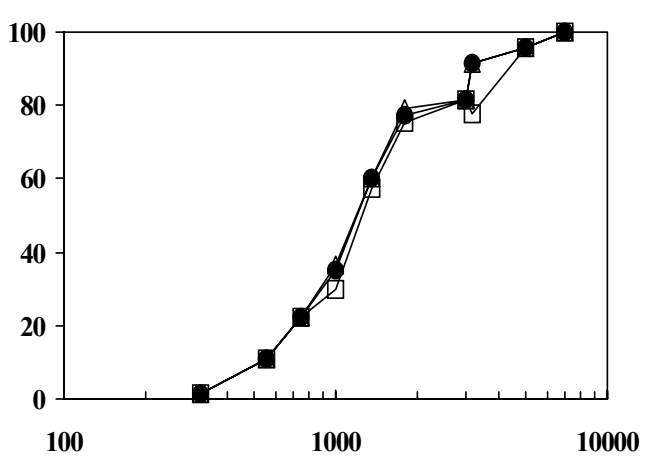

$\mu g$ clorpirifós/ml de acetona

Figura 2 - Curvas de concentração-mortalidade de Blattella germanica avaliada com $24(\square), 48(\bullet)$ e $72(\Delta)$ h após aplicação tópica com o inseticida clorpirifós para a linhagem SUS e populações RJ-1, RJ-2 e SP-1. 
Tabela 2. Respostas de dose-mortalidade da linhagem suscetível (SUS) e das populações RJ-1, RJ-2 e SP-1 de Blattella germanica avaliadas com 24, 48 e 72 h após aplicação tópica com o inseticida clorpirifós.

\begin{tabular}{|c|c|c|c|c|c|c|c|}
\hline $\begin{array}{l}\text { Linhagem/ } \\
\text { Populações }\end{array}$ & $\begin{array}{c}\text { Tempo } \\
\text { de } \\
\text { avaliação }\end{array}$ & $\mathbf{n}^{\mathbf{a}}$ & $\begin{array}{c}\mathrm{DL}_{50}{ }^{\mathrm{b}} \\
(\mathrm{IC} 95 \%)\end{array}$ & $\begin{array}{l}\text { Coeficiente } \\
\text { angular } \\
( \pm \text { ep })\end{array}$ & $\chi^{2}$ & $\mathrm{gl}^{\mathrm{c}}$ & $\mathbf{R R}^{\mathbf{d}}$ \\
\hline \multirow{3}{*}{ SUS } & $24 \mathrm{~h}$ & \multirow{2}{*}{520} & $\begin{array}{l}4,49 \\
(-)\end{array}$ & $3,45( \pm 0,25)$ & 95,09 & 4 & - \\
\hline & $48 \mathrm{~h}$ & & $\begin{array}{c}4,16 \\
(2,80-5,33)\end{array}$ & $4,71( \pm 0,46)$ & 13,19 & 4 & - \\
\hline & $72 \mathrm{~h}$ & 370 & $\begin{array}{c}4,32 \\
(2,26-6,45)\end{array}$ & $4,41( \pm 0,51)$ & 16,87 & 4 & - \\
\hline \multirow{3}{*}{ RJ-1 } & $24 \mathrm{~h}$ & \multirow{3}{*}{589} & $\begin{array}{c}21,95 \\
(19,41-24,95)\end{array}$ & $4,13( \pm 0,30)$ & 9,21 & 6 & 4,89 \\
\hline & $48 \mathrm{~h}$ & & $\begin{array}{c}20,72 \\
(18,99-22,58)\end{array}$ & $4,14( \pm 0,32)$ & 5,26 & 6 & 4,98 \\
\hline & $72 \mathrm{~h}$ & & $\begin{array}{c}20,56 \\
(18,00-23,32)\end{array}$ & $4,14( \pm 0,34)$ & 7,11 & 6 & 4,76 \\
\hline \multirow{3}{*}{ RJ-2 } & $24 \mathrm{~h}$ & \multirow{3}{*}{707} & $\begin{array}{c}28,71 \\
(26,02-31,63)\end{array}$ & $3,30( \pm 0,21)$ & 8,01 & 8 & 6,39 \\
\hline & $48 \mathrm{~h}$ & & $\begin{array}{c}27,54 \\
(24,80-30,50)\end{array}$ & $3,29( \pm 0,21)$ & 8,89 & 8 & 6,62 \\
\hline & $72 \mathrm{~h}$ & & $\begin{array}{c}27,09 \\
(24,16-30,28)\end{array}$ & $3,30( \pm 0,21)$ & 10,55 & 8 & 6,27 \\
\hline \multirow{3}{*}{ SP-1 } & $24 \mathrm{~h}$ & & $\begin{array}{c}132,69 \\
(114,18-163,21)\end{array}$ & $4,39( \pm 0,45)$ & 4,99 & 4 & 29,55 \\
\hline & $48 \mathrm{~h}$ & 380 & $\begin{array}{c}125,08 \\
(106,83-154,92)\end{array}$ & $4,45( \pm 0,45)$ & 6,00 & 4 & 30,06 \\
\hline & $72 \mathrm{~h}$ & & $\begin{array}{c}112,10 \\
(102,03-125,04)\end{array}$ & $4,07( \pm 0,40)$ & 3,65 & 4 & 25,95 \\
\hline $\begin{array}{l}\mathrm{a} \\
\mathrm{a}=\text { núm } \\
\mathrm{b} \\
\mathrm{c} \text { dose leta } \\
\mathrm{c}=\text { grau } \\
\mathrm{d} \\
\mathrm{RR}=\mathrm{raz} \\
\mathrm{e} \\
\text { não foi } \mathrm{p}\end{array}$ & $\begin{array}{l}\text { lero de inset } \\
\text { us de liberda }(\mu \mathrm{g} \\
\text { zão de resist } \\
\text { possível esti }\end{array}$ & $\begin{array}{l}\text { s testa } \\
\text { clorpiri } \\
\text { de } \\
\text { incia (l } \\
\text { nar o I }\end{array}$ & S/mg) para cada tempo & avaliação & SUS) & & \\
\hline
\end{tabular}


Nos resultados de concentração-mortalidade dessas mesmas linhagens de $B$. germanica avaliadas com 24, 48 e $72 \mathrm{~h}$ após aplicação tópica com o inseticida fipronil também foi observado que o melhor tempo de avaliação foi com 48 h (Figura 3 e Tabela 3). A resposta com fipronil em B. germanica foi mais lenta do que com deltametrina e clorpirifós. Resultados consistentes de resposta foram possíveis somente a partir da avaliação com $48 \mathrm{~h}$ após a aplicação. Em algumas avaliações também não foi possível estimar o IC, pois os dados não se adequaram ao modelo de Probit, como por exemplo com 24 e $72 \mathrm{~h}$ para a linhagem SUS.

Os resultados da análise de Probit para o fipronil mostraram diferenças significativas na suscetibilidade de $B$. germanica a esse inseticida (Tabela 3). As razões de resistência (RR) calculadas para as populações RJ-1, RJ-2 e SP-1 foram de 2,09; 2,00 e 2,70 vezes; respectivamente. Os coeficientes angulares das populações de campo testadas com o inseticida fipronil também foram menores do que o coeficiente angular da linhagem SUS. Esses resultados sugerem a presença de variabilidade genética que confere resistência a fipronil nas populações de B. germanica avaliadas. 
Linhagem SUS

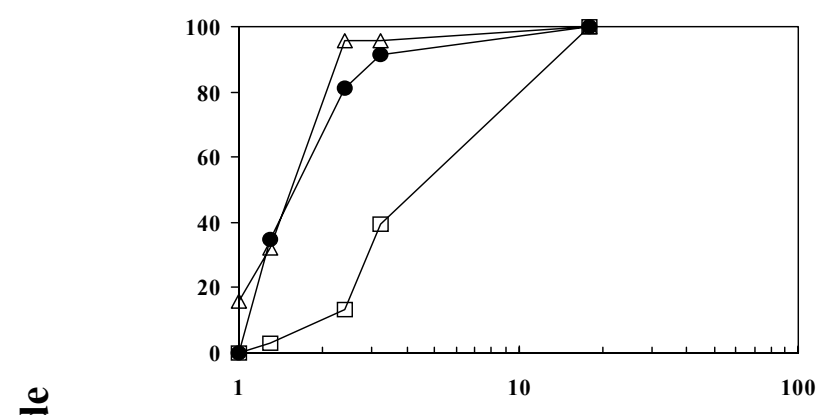

População RJ-2

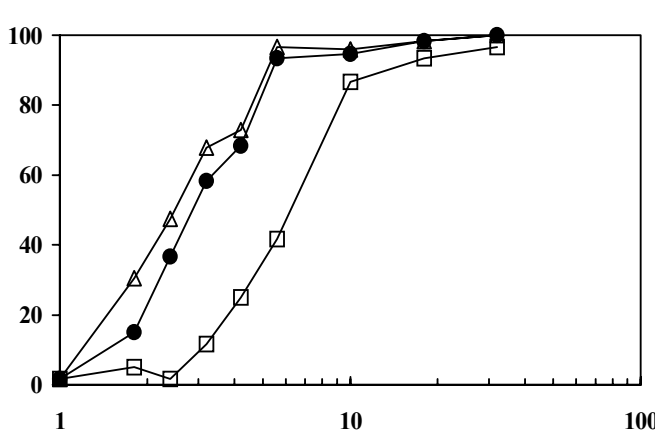

População RJ-1

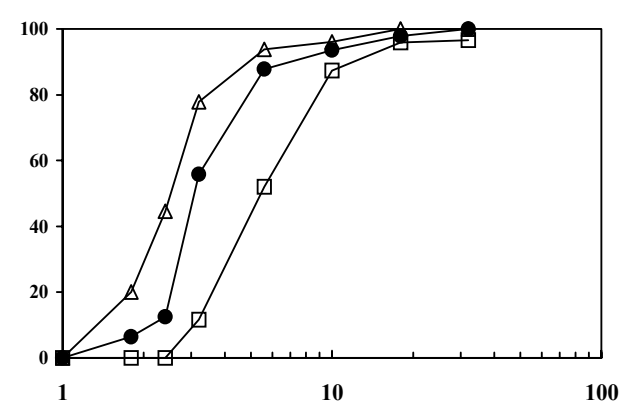

População SP-1

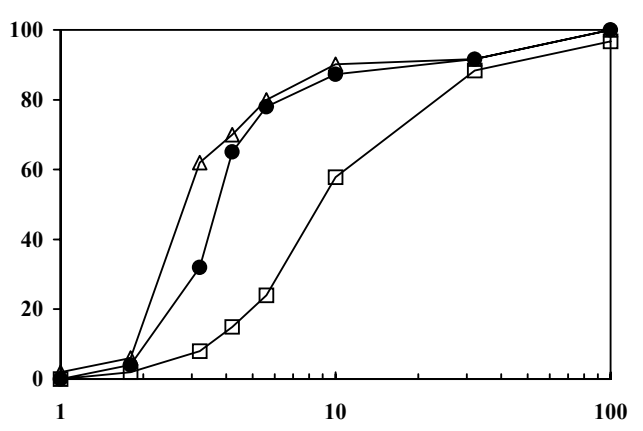

$\mu \mathrm{g}$ fipronil/ml de acetona

Figura 3 - Curvas de concentração-mortalidade de Blattella germanica avaliada com $24(\square), 48(\bullet)$ e $72(\Delta)$ h após aplicação tópica com o inseticida fipronil para a linhagem SUS e populações RJ-1, RJ-2 e SP-1. 
Tabela 3. Respostas de dose-mortalidade da linhagem suscetível (SUS) e das populações RJ-1, RJ-2 e SP-1 de Blattella germanica avaliadas com 24, 48 e 72 h após aplicação tópica com o inseticida fipronil.

\begin{tabular}{|c|c|c|c|c|c|c|c|}
\hline $\begin{array}{l}\text { Linhagem/ } \\
\text { Populações }\end{array}$ & $\begin{array}{c}\text { Tempo } \\
\text { de } \\
\text { avaliação }\end{array}$ & $n^{a}$ & $\begin{array}{c}\mathrm{DL}_{50}{ }^{\mathrm{b}} \\
(\mathrm{IC} \mathrm{95 \%})\end{array}$ & $\begin{array}{c}\text { Coeficiente } \\
\text { angular } \\
( \pm \text { ep })\end{array}$ & $\chi^{2}$ & $\mathrm{gl}^{\mathrm{c}}$ & $\mathbf{R R}^{\mathrm{d}}$ \\
\hline \multirow{3}{*}{ SUS } & $24 \mathrm{~h}$ & \multirow{2}{*}{520} & $\begin{array}{c}0,066 \\
(-)^{\mathrm{e}}\end{array}$ & $\begin{array}{c}5,29 \\
( \pm 1,12)\end{array}$ & 3,89 & 3 & - \\
\hline & $48 \mathrm{~h}$ & & $\begin{array}{c}0,033 \\
(0,023-0,043)\end{array}$ & $\begin{array}{c}6,03 \\
( \pm 0,45)\end{array}$ & 14,78 & 3 & - \\
\hline & $72 \mathrm{~h}$ & 370 & $\begin{array}{l}0,026 \\
(-)^{e}\end{array}$ & $\begin{array}{c}5,94 \\
( \pm 0,54)\end{array}$ & 20,05 & 3 & - \\
\hline \multirow{3}{*}{ RJ-1 } & $24 \mathrm{~h}$ & \multirow{3}{*}{424} & $\begin{array}{c}0,12 \\
(0,079-0,18)\end{array}$ & $\begin{array}{c}4,32 \\
( \pm 0,35)\end{array}$ & 43,29 & 6 & 1,82 \\
\hline & $48 \mathrm{~h}$ & & $\begin{array}{c}0,069 \\
(0,053-0,091)\end{array}$ & $\begin{array}{c}4,05 \\
( \pm 0,34)\end{array}$ & 21,56 & 6 & 2,09 \\
\hline & $72 \mathrm{~h}$ & & $\begin{array}{c}0,051 \\
(0,039-0,064)\end{array}$ & $\begin{array}{c}4,20 \\
( \pm 0,39)\end{array}$ & 18,55 & 6 & 1,96 \\
\hline \multirow{3}{*}{ RJ-2 } & $24 \mathrm{~h}$ & \multirow{3}{*}{525} & $\begin{array}{c}0,13 \\
(0,11-0,17)\end{array}$ & $\begin{array}{c}3,58 \\
( \pm 0,26)\end{array}$ & 18,95 & 7 & 1,97 \\
\hline & $48 \mathrm{~h}$ & & $\begin{array}{c}0,066 \\
(0,056-0,078)\end{array}$ & $\begin{array}{c}3,75 \\
( \pm 0,30)\end{array}$ & 15,24 & 7 & 2,00 \\
\hline & $72 \mathrm{~h}$ & & $\begin{array}{c}0,056 \\
(0,044-0,067)\end{array}$ & $\begin{array}{c}3,50 \\
( \pm 0,30)\end{array}$ & 18,55 & 7 & 2,15 \\
\hline \multirow{3}{*}{ SP-1 } & $24 \mathrm{~h}$ & \multirow{3}{*}{401} & $\begin{array}{c}0,21 \\
(0,17-0,26)\end{array}$ & $\begin{array}{c}2,54 \\
( \pm 0,22)\end{array}$ & 6,78 & 6 & 3,18 \\
\hline & $48 \mathrm{~h}$ & & $\begin{array}{c}0,089 \\
(0,045-0,16)\end{array}$ & $\begin{array}{c}2,70 \\
( \pm 0,24)\end{array}$ & 51,72 & 6 & 2,70 \\
\hline & $72 \mathrm{~h}$ & & $\begin{array}{c}0,072 \\
(0,029-0,13)\end{array}$ & $\begin{array}{c}2,49 \\
( \pm 0,23)\end{array}$ & 61,85 & 6 & 2,77 \\
\hline
\end{tabular}

\footnotetext{
$\mathrm{n}=$ número de insetos testados

${ }^{\mathrm{b}}$ dose letal média ( $\mu \mathrm{g}$ fipronil/mg) para cada época de avaliação

c $\mathrm{gl}=$ graus de liberdade

d $R R=$ razão de resistência $\left(\mathrm{DL}_{50}\right.$ da população em estudo/ $\mathrm{DL}_{50}$ da linhagem SUS)

e não foi possível estimar o IC
} 


\subsubsection{Bioensaio de contato tarsal}

O método de bioensaio de contato tarsal não proporcionou uma boa discriminação entre a linhagem suscetível (SUS) e as populações de $B$. germanica testadas com os inseticidas deltametrina e clorpirifós. As respostas da linhagem SUS e das populações RJ-1, RJ-2 e SP-1 de B. germanica encontram-se na Figura 4 e Tabela 4 para a deltametrina e Figura 5 e Tabela 5 para o clorpirifós.

Para o inseticida deltametrina, observa-se através da Figura 4 e Tabela 4 que o método de contato tarsal possibilitou uma menor discriminação entre a linhagem SUS e as populações de campo quando comparado com os resultados obtidos com o método de aplicação tópica (Figura 1 e Tabela 1). O critério de avaliação baseado no efeito knockdown não proporcionou discriminação entre as populações. O critério de mortalidade com 12, 24, 48 e $72 \mathrm{~h}$ também não foi eficiente para detectar a resistência, pois não apresentaram diferenças significativas entre si e nem mesmo entre as populações. A mortalidade obtida para o inseticida deltametrina $\left(1,70 \mu \mathrm{g}\right.$ deltametrina $\left./ \mathrm{cm}^{2}\right)$ foi de $100 \%, 99,81 \%, 99,84 \%$ e $100 \%$ para a linhagem SUS e populações RJ-1, RJ-2 e SP-1, respectivamente.

As razões de resistência obtidas através do bioensaio de contato tarsal para as populações RJ-1, RJ-2 e SP-1 foram de 2,21; 2,25 e 1,98 vezes; respectivamente (Tabela 4). As baixas razões de resistência obtidas neste experimento foram semelhantes aos obtidos por Wadleigh et al. (1989) quando testaram resíduos de cipermetrina na dose de $1,92 \mu \mathrm{g} / \mathrm{cm}^{2}$. 


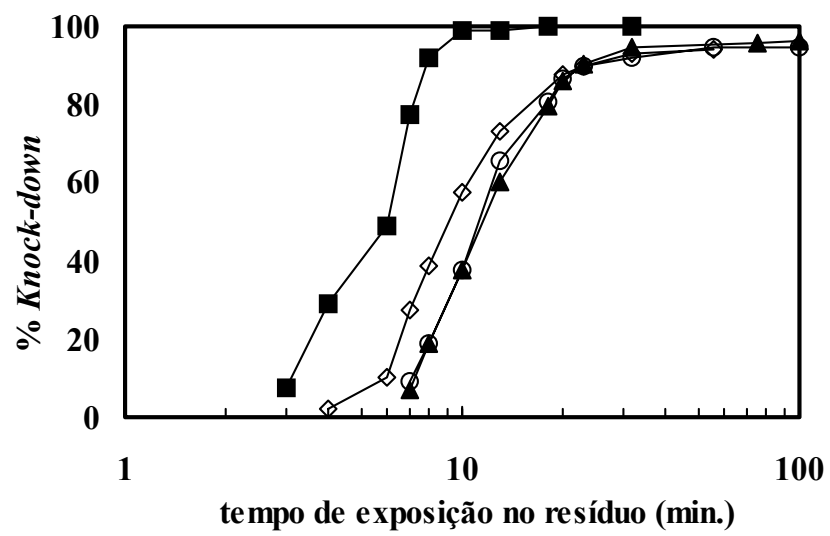

Figura 4 - Curvas de tempo-resposta de knock-down da linhagem suscetível (ם) e das

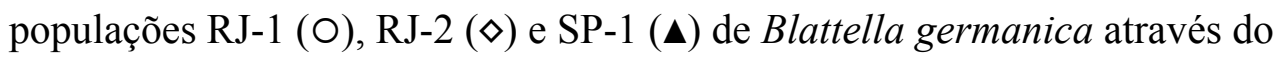
bioensaio de contato tarsal com resíduo de $1,70 \mu \mathrm{g}$ deltametrina $/ \mathrm{cm}^{2}$ de superfície.

Tabela 4. Resultados de tempo-resposta da linhagem suscetível (SUS) e das populações RJ-1, RJ-2 e SP-1 de Blattella germanica através do bioensaio de contato tarsal com resíduo de $1,70 \mu \mathrm{g}$ deltametrina $/ \mathrm{cm}^{2}$ de superfície.

\begin{tabular}{|c|c|c|c|c|c|c|}
\hline $\begin{array}{l}\text { Linhagem/ } \\
\text { Populações }\end{array}$ & $\mathbf{n}^{\mathbf{a}}$ & $\begin{array}{c}K_{50}{ }^{b} \\
(I C 95 \%)\end{array}$ & $\begin{array}{l}\text { Coeficiente } \\
\text { angular } \\
\pm(\mathbf{e p})\end{array}$ & $\chi^{2}$ & $\mathrm{gl}^{\mathrm{c}}$ & $\mathbf{R R}^{\mathbf{d}}$ \\
\hline SUS & 448 & $\begin{array}{c}5,25 \\
(4,57-5,96)\end{array}$ & $5,90( \pm 0,17)$ & 205,90 & 9 & - \\
\hline RJ-1 & 439 & $\begin{array}{c}11,62 \\
(5,29-16,73)\end{array}$ & $2,94( \pm 0,91)$ & 589,73 & 8 & 2,21 \\
\hline RJ-2 & 543 & $\begin{array}{c}11,80 \\
(5,58-17,03)\end{array}$ & $3,13( \pm 0,87)$ & 787,34 & 8 & 2,25 \\
\hline SP-1 & 450 & $\begin{array}{c}10,41 \\
(8,17-13,05)\end{array}$ & $3,42( \pm 0,88)$ & 298,91 & 8 & 1,98 \\
\hline \multicolumn{7}{|c|}{$\begin{array}{l}\mathrm{n}=\text { número médio de indivíduos testados } \\
\text { tempo knock-down médio (minutos) } \\
\mathrm{gl}=\text { graus de liberdade }\end{array}$} \\
\hline
\end{tabular}


O método de contato tarsal, avaliado através do critério de insetos moribundos também não permitiu a separação entre as populações para o inseticida clorpirifós testado na dose de 8,40 $\mu$ g clorpirifós $/ \mathrm{cm}^{2}$ (Figura 5). A mortalidade com 12, 24, 48 e 72 $\mathrm{h}$ foi de $100 \%$ para todos os tempos de avaliações nas populações testadas.

As razões de resistência obtidas através do bioensaio de contato tarsal para as populações RJ-1, RJ-2 e SP-1 foram de apenas 1,35; 1,47 e 1,70 vezes; respectivamente (Tabela 5). Os dados obtidos neste experimento foram semelhantes aos obtidos por Milio et al. (1987); Schal (1988) e Wadleigh et al. (1989) ao testarem resíduos de clorpirifós nas doses de 5,0;16,5 e 4,81 $\mu \mathrm{g} / \mathrm{cm}^{2}$, respectivamente.

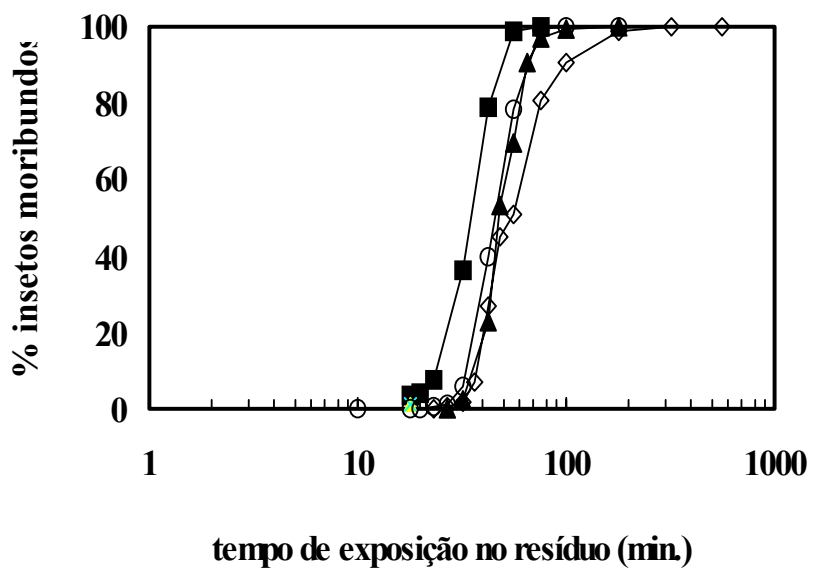

Figura 5 - Curvas de tempo-resposta de insetos moribundos da linhagem suscetível (ロ) e

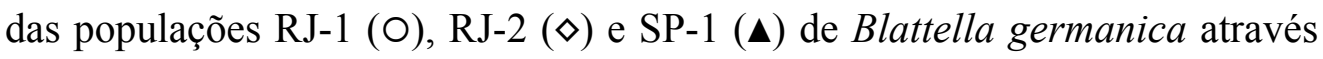
do bioensaio de contato tarsal com resíduo de $8,49 \mu \mathrm{g}$ clorpirifós $/ \mathrm{cm}^{2}$ de superfície. 
Tabela 5. Resultados de tempo-resposta da linhagem suscetível (SUS) e das populações RJ-1, RJ-2 e SP-1 de Blattella germanica através do bioensaio de contato tarsal com resíduo de $8,49 \mu \mathrm{g}$ clorpirifós $/ \mathrm{cm}^{2}$ de superfície.

\begin{tabular}{|c|c|c|c|c|c|c|}
\hline $\begin{array}{l}\text { Linhagem/ } \\
\text { Populações }\end{array}$ & $\mathbf{n}^{\mathbf{a}}$ & $\begin{array}{c}\text { TL }_{50}{ }^{b} \\
(\text { IC 95\%) }\end{array}$ & $\begin{array}{l}\text { Coeficiente } \\
\text { angular } \\
\text { ( } \pm \text { ep })\end{array}$ & $\chi^{2}$ & $\mathrm{gl}^{\mathrm{c}}$ & $\mathbf{R R}^{\mathrm{d}}$ \\
\hline SUS & 727 & $\begin{array}{c}33,56 \\
(31,32-36,22)\end{array}$ & $8,30( \pm 0,19)$ & 60,31 & 5 & - \\
\hline RJ-1 & 542 & $\begin{array}{c}45,48 \\
(43,33-47,77)\end{array}$ & $9,70( \pm 0,27)$ & 60,30 & 9 & 1,35 \\
\hline RJ-2 & 479 & $\begin{array}{c}49,45 \\
(48,32-50,59)\end{array}$ & $10,25( \pm 0,30)$ & 12,57 & 7 & 1,47 \\
\hline SP-1 & 415 & $\begin{array}{c}57,08 \\
(43,81-78,02)\end{array}$ & $6,11( \pm 0,17)$ & 941,72 & 10 & 1,70 \\
\hline $\begin{array}{ll}\mathrm{a} & \mathrm{n}=\text { númerc } \\
\mathrm{b} & \text { tempo let } \\
\mathrm{c} & \mathrm{gl}=\text { graus } \\
\mathrm{d} & \mathrm{RR}=\text { razã }\end{array}$ & $\begin{array}{l}\text { édio d } \\
\text { lédio } \\
\text { liberd } \\
\text { a resis }\end{array}$ & $\begin{array}{l}\text { víduos testados } \\
\text { os) } \\
\text { (TL }_{50} \text { da populac }\end{array}$ & do/TT do 1; & SUS) & & \\
\hline
\end{tabular}

A Tabela 6 mostra um resumo comparativo das razões de resistência obtidas com os 2 tipos de bioensaio para os inseticidas deltametrina e clorpirifós nas populações testadas. O bioensaio de aplicação tópica, através da estimativa da $\mathrm{DL}_{50}$, mostrou ser uma técnica mais eficiente do que o de contato tarsal para se detectar a resistência aos 2 inseticidas testados devido à melhor discriminação entre a linhagem suscetível e as populações de campo.

As razões de resistência a deltametrina na população SP-1 foram de 105 vezes com o bioensaio de aplicação tópica e somente de 2 vezes com o bioensaio de contato tarsal (Tabela 6). Estes resultados foram semelhantes aos obtidos por Zhai \& Robinson (1996) que encontraram razões de resistência a cipermetrina em B. germanica de 123 
vezes com o bioensaio de aplicação tópica e somente 3 vezes com o bioensaio de contato tarsal.

Para o clorpirifós na população SP-1, foi obtida a mesma tendência para as razões de resistência. Maiores razões de resistência foram obtidas com o bioensaio de aplicação tópica (30 vezes) do que com o bioensaio de contato tarsal (aproximadamente 2 vezes). Resultados semelhantes foram reportados por Milio et al. (1987) que encontraram uma razão de resistência ao inseticida clorpirifós em $B$. germanica da ordem de 14,3 e 7,8 vezes com os bioensaios de aplicação tópica e contato tarsal, respectivamente.

Tabela 6. Comparação da razão de resistência das populações RJ-1, RJ-2 e SP-1 de Blattella germanica para os inseticidas deltametrina e clorpirifós obtida através dos bioensaios de aplicação tópica e contato tarsal.

\begin{tabular}{|c|c|c|c|c|}
\hline \multicolumn{5}{|c|}{ Razão de Resistência } \\
\hline \multirow{2}{*}{ Populações } & \multicolumn{2}{|c|}{ Deltametrina } & \multicolumn{2}{|c|}{ Clorpirifós } \\
\hline & $\begin{array}{l}\text { Aplicação } \\
\text { tópica }\end{array}$ & $\begin{array}{c}\text { Contato } \\
\text { tarsal }\end{array}$ & $\begin{array}{c}\text { Aplicação } \\
\text { tópica }\end{array}$ & $\begin{array}{c}\text { Contato } \\
\text { tarsal }\end{array}$ \\
\hline RJ-1 & 10,32 & 2,21 & 4,98 & 1,35 \\
\hline RJ-2 & 14,08 & 2,25 & 6,62 & 1,47 \\
\hline SP-1 & 100,80 & 1,98 & 30,06 & 1,70 \\
\hline
\end{tabular}


Apesar de ser recomendada pela Organização Mundial de Saúde (1970) para a detecção da resistência de $B$. germanica a inseticidas, a técnica de bioensaio de contato tarsal não foi um método eficiente, pois não foi possível discriminar as populações apresentando razões de resistência baixas. O bioensaio de contato tarsal pode ser considerado um método mais realístico do que o bioensaio de aplicação tópica, embora no campo os insetos não fiquem continuamente em contato com o resíduo do inseticida. O efeito knock-down como critério de resposta para a deltametrina (Tabela 4) e insetos moribundos para o clorpirifós (Tabela 5), proporcionaram baixas intensidades de resistência. A mortalidade como critério de avaliação para o bioensaio de contato tarsal também não foi eficiente, pois todos os insetos morreram nas populações testadas.

Muitos trabalhos reportados têm sugerido que o método de contato tarsal pode não detectar adequadamente a resistência em populações que apresentem falhas no controle indicando que poderiam não ser resistentes (Milio et al., 1987; Schal, 1988; Zhai \& Robinson, 1992), porque pelo método de contato tarsal, o nível de sensibilidade ao inseticida pode ser influenciado pelas diferenças no caminhamento das baratas provenientes do campo. As baratas caminham na superfície tratada e elas são expostas ao inseticida que penetra através do seu tarso. Um aumento na locomoção resulta num aumento da quantidade de inseticida acumulado no tarso de cada perna (Zhai \& Robinson, 1992).

Rust \& Reierson (1991) concluíram que os resultados obtidos nos métodos de aplicação tópica e de contato tarsal, nem sempre possam ser diretamente comparáveis, porque as razões de resistência obtidas através do método de aplicação tópica tendem a ser superiores as obtidas pelo método de contato tarsal, especialmente com certos organofosforados como o clorpirifós, onde a resistência parece não atingir altos níveis. A explicação apresentada para esse fato foi devido à diferença de penetração do inseticida no corpo do inseto, especialmente entre os métodos de aplicação tópica e de contato tarsal, pois eles podem não estar medindo o mesmo fenômeno ou estar medindo por diferentes meios.

Scott et al. (1986) mostraram que uma linhagem de B. germanica resistente a piretróides foi resistente a cipermetrina e ciflutrina pelo método de bioensaio de 
aplicação tópica, porém não foi pelo método de contato tarsal. Isso pode ser explicado se a taxa de penetração do inseticida for mais lenta pelo método de aplicação tópica do que pelo método de contato tarsal, fazendo com que o mecanismo de resistência possa controlar doses aparentemente mais altas e produzir razões de resistência maiores pelo método de aplicação tópica. A outra explicação seria possivelmente a forma de absorção do inseticida através do método de contato tarsal, porque inseticida adicional está sendo continuamente absorvido do substrato, com isso o mecanismo de resistência poderia ser superado resultando em intensidades de resistência mais baixas (Cochran, 1995). Por outro lado, Cochran (1995) verificou que a discrepância das razões de resistência entre os métodos de bioensaio testados seja somente um problema quando estas são baixas, pois se uma concentração excessivamente alta for usada no bioensaio de contato tarsal, seria equivalente a realizar testes com doses ou concentrações letais que matem todos os insetos (Cochran, 1997). A concentração do inseticida usada no método de contato tarsal é crítica porque é possível sobrepor o mecanismo de resistência com um excesso de inseticida. Portanto, as baixas razões de resistência observadas no presente estudo podem estar associadas à dose dos inseticidas avaliados.

\subsubsection{Monitoramento da suscetibilidade de populações de Blattella germanica a deltametrina, clorpirifós e fipronil}

Diferenças estatísticas significativas na suscetibilidade aos inseticidas deltametrina (Tabela 7), clorpirifós (Tabela 8) e fipronil (Tabela 9) foram encontradas em populações de campo de $B$. germanica por meio de bioensaio de aplicação tópica.

Os resultados de monitoramento da suscetibilidade a deltametrina mostraram diferenças significativas entre as populações (Tabela 7). As intensidades de resistência variaram de 10,32 (RJ-1) a 100,80 (SP-1) vezes. Os valores do coeficiente angular das regressões de concentração-resposta obtidas através da análise de Probit foram todos menores que o da linhagem suscetível, o que evidencia a heterogeneidade das populações com respeito à resistência a deltametrina. 
Diferenças significativas na suscetibilidade entre as populações foram também observadas para o clorpirifós (Tabela 8) e fipronil (Tabela 9). As razões de resistência para clorpirifós variaram de 4,98 (RJ-1) a 30,06 (SP-1) vezes e para fipronil de 2,00 (RJ2) a 6,36 (RJ-3). As intensidades de resistência de B. germanica a clorpirifós e fipronil foram menores do que as obtidas para deltametrina.

Pode ser observado que não houve sobreposição dos intervalos de confiança das $\mathrm{DL}_{50}$ das populações testadas com a $\mathrm{DL}_{50}$ da linhagem suscetível para os 3 produtos testados, evidenciando a presença de resistência de B. germanica a esses inseticidas, principalmente com a população SP-1 que apresentou uma RR muito alta para o clorpirifós (30,06 vezes) e para a deltametrina (100,80 vezes). Com relação ao fipronil, apesar de ser um produto relativamente novo no mercado, foi observada uma razão de resistência de 6,36 vezes na população RJ-3 (Tabela 9). Possivelmente, há problemas de resistência cruzada entre fipronil e outros inseticidas utilizados há mais tempo no controle de B. germanica no Brasil (a ser discutido no Capítulo 4). 
Tabela 7. Respostas de dose-mortalidade da linhagem suscetível (SUS) e das populações de Blattella germanica coletadas em diferentes locais após aplicação tópica com o inseticida deltametrina.

\begin{tabular}{|c|c|c|c|c|c|c|}
\hline $\begin{array}{l}\text { Linhagem/ } \\
\text { Populações }\end{array}$ & $\mathbf{n}^{\mathbf{a}}$ & $\begin{array}{c}\mathrm{DL}_{50}{ }^{b} \\
(\mathrm{IC} 95 \%)\end{array}$ & $\begin{array}{c}\text { Coeficiente } \\
\text { angular } \\
( \pm \text { ep })\end{array}$ & $\chi^{2}$ & $\mathrm{gl}^{\mathrm{c}}$ & $\mathbf{R R}^{\mathbf{d}}$ \\
\hline SUS & 740 & $\begin{array}{c}0,25 \\
(0,18-0,31)\end{array}$ & $\begin{array}{c}2,83 \\
( \pm 0,17)\end{array}$ & 12,34 & 4 & - \\
\hline PIR-1 & 716 & $\begin{array}{c}2,87 \\
(2,27-3,57)\end{array}$ & $\begin{array}{c}1,95 \\
( \pm 0,14)\end{array}$ & 15,79 & 9 & 11,48 \\
\hline PIR-2 & 480 & $\begin{array}{c}6,55 \\
(4,14-9,44)\end{array}$ & $\begin{array}{c}1,62 \\
( \pm 0,15)\end{array}$ & 7,50 & 5 & 26,20 \\
\hline SP-1 & 450 & $\begin{array}{c}25,20 \\
(13,21-63,24)\end{array}$ & $\begin{array}{c}1,25 \\
( \pm 0,13)\end{array}$ & 27,36 & 6 & 100,80 \\
\hline SP-2 & 579 & $\begin{array}{c}8,32 \\
(4,17-13,68)\end{array}$ & $\begin{array}{c}1,41 \\
( \pm 0,12)\end{array}$ & 15,46 & 5 & 33,28 \\
\hline SP-3 & 770 & $\begin{array}{c}5,39 \\
(4,00-7,15)\end{array}$ & $\begin{array}{c}1,39 \\
( \pm 0,087)\end{array}$ & 10,50 & 7 & 21,56 \\
\hline SP-4 & 449 & $\begin{array}{c}5,62 \\
(3,97-7,37)\end{array}$ & $\begin{array}{c}2,04 \\
( \pm 0,20)\end{array}$ & 10,32 & 6 & 22,48 \\
\hline RJ-1 & 880 & $\begin{array}{c}2,58 \\
(1,67-3,66)\end{array}$ & $\begin{array}{c}1,62 \\
( \pm 0,11)\end{array}$ & 20,63 & 6 & 10,32 \\
\hline RJ-2 & 709 & $\begin{array}{c}3,52 \\
(2,57-4,57)\end{array}$ & $\begin{array}{c}1,56 \\
( \pm 0,11)\end{array}$ & 8,70 & 6 & 14,08 \\
\hline RJ-3 & 320 & $\begin{array}{c}7,81 \\
(0,63-24,48)\end{array}$ & $\begin{array}{c}0,90 \\
( \pm 0,14)\end{array}$ & 11,93 & 5 & 31,24 \\
\hline
\end{tabular}


Tabela 8. Respostas de dose-mortalidade da linhagem suscetível (SUS) e das populações de Blattella germanica coletadas em diferentes locais após aplicação tópica com o inseticida clorpirifós.

\begin{tabular}{|c|c|c|c|c|c|c|}
\hline $\begin{array}{l}\text { Linhagem/ } \\
\text { População }\end{array}$ & $\mathrm{n}^{\mathrm{a}}$ & $\begin{array}{c}\mathrm{DL}_{50}^{b} \\
(\mathrm{IC} 95 \%)\end{array}$ & $\begin{array}{c}\text { Coeficiente } \\
\text { angular } \\
( \pm \mathrm{ep})\end{array}$ & $\chi^{2}$ & $\mathrm{gl}^{\mathrm{c}}$ & $\mathbf{R R}^{\mathrm{d}}$ \\
\hline SUS & 520 & $\begin{array}{c}4,16 \\
(2,80-5,33)\end{array}$ & $\begin{array}{c}4,71 \\
( \pm 0,46)\end{array}$ & 13,19 & 4 & - \\
\hline PIR-1 & 520 & $\begin{array}{c}32,44 \\
(29,06-36,48)\end{array}$ & $\begin{array}{c}2,60 \\
( \pm 0,21)\end{array}$ & 2,48 & 5 & 7,80 \\
\hline PIR-2 & 530 & $\begin{array}{c}42,65 \\
(35,23-51,08)\end{array}$ & $\begin{array}{c}3,45 \\
( \pm 0,24)\end{array}$ & 9,13 & 5 & 10,25 \\
\hline SP-1 & 380 & $\begin{array}{c}125,08 \\
(106,83-154,92)\end{array}$ & $\begin{array}{c}4,45 \\
( \pm 0,45)\end{array}$ & 6,00 & 4 & 30,06 \\
\hline SP-2 & 664 & $\begin{array}{c}28,38 \\
(24,67-32,17)\end{array}$ & $\begin{array}{c}2,19 \\
( \pm 0,18)\end{array}$ & 1,83 & 7 & 6,82 \\
\hline SP-3 & 600 & $\begin{array}{c}41,08 \\
(36,12-46,48)\end{array}$ & $\begin{array}{c}3,15 \\
( \pm 0,21)\end{array}$ & 8,58 & 7 & 9,87 \\
\hline SP-4 & 385 & $\begin{array}{c}108,40 \\
(89,66-136,25)\end{array}$ & $\begin{array}{c}3,04 \\
( \pm 0,33)\end{array}$ & 7,22 & 5 & 26,06 \\
\hline RJ-1 & 589 & $\begin{array}{c}20,72 \\
(18,99-22,58)\end{array}$ & $\begin{array}{c}4,14 \\
( \pm 0,32)\end{array}$ & 5,26 & 6 & 4,98 \\
\hline RJ-2 & 707 & $\begin{array}{c}27,54 \\
(24,80-30,50)\end{array}$ & $\begin{array}{c}3,29 \\
( \pm 0,21)\end{array}$ & 8,89 & 8 & 6,62 \\
\hline RJ-3 & 673 & $\begin{array}{c}47,75 \\
(39,78-56,76)\end{array}$ & $\begin{array}{c}1,64 \\
( \pm 0,15)\end{array}$ & 4,43 & 6 & 11,48 \\
\hline
\end{tabular}

${ }^{\mathrm{a}} \mathrm{n}=$ número de insetos testados

b dose letal média ( $\mu \mathrm{g}$ clorpirifós/mg)

c $\mathrm{gl}=$ graus de liberdade

d $\mathrm{RR}=$ razão da resistência $\left(\mathrm{DL}_{50}\right.$ da população em estudo/ $\mathrm{DL}_{50}$ da linhagem $\left.\mathrm{SUS}\right)$ 
Tabela 9. Respostas de dose-mortalidade da linhagem suscetível (SUS) e das populações de Blattella germanica coletadas em diferentes locais após aplicação tópica com o inseticida fipronil.

\begin{tabular}{|c|c|c|c|c|c|c|}
\hline \multirow{2}{*}{$\begin{array}{l}\text { Linhagem/ } \\
\text { População }\end{array}$} & \multicolumn{6}{|c|}{ Coeficiente } \\
\hline & $\mathrm{n}^{\mathrm{a}}$ & $\begin{array}{c}\mathrm{DL}_{50}{ }^{b} \\
(\mathrm{IC} 95 \%)\end{array}$ & $\begin{array}{c}\text { Angular } \\
\text { (士 ep) }\end{array}$ & $\chi^{2}$ & $\mathrm{gl}^{\mathrm{c} *}$ & $\mathbf{R R}^{\mathrm{d}}$ \\
\hline SUS & 520 & $\begin{array}{c}0,033 \\
(0,023-0,043)\end{array}$ & $\begin{array}{c}6,03 \\
( \pm 0,45)\end{array}$ & 14,77 & 3 & - \\
\hline RJ-1 & 424 & $\begin{array}{c}0,069 \\
(0,053-0,091)\end{array}$ & $\begin{array}{c}4,05 \\
( \pm 0,34)\end{array}$ & 21,56 & 6 & 2,09 \\
\hline RJ-2 & 525 & $\begin{array}{c}0,066 \\
(0,056-0,078)\end{array}$ & $\begin{array}{c}3,75 \\
( \pm 0,30)\end{array}$ & 15,24 & 7 & 2,00 \\
\hline RJ-3 & 409 & $\begin{array}{c}0,21 \\
(0,13-0,33)\end{array}$ & $\begin{array}{c}1,64 \\
( \pm 0,15)\end{array}$ & 15,38 & 6 & 6,36 \\
\hline $\begin{array}{ll}\mathrm{a} & \mathrm{n}=\text { númer } \\
\mathrm{b} & \text { dose letal } \\
\mathrm{c} & \mathrm{gl}=\text { graus } \\
\mathrm{d} & \mathrm{RR}=\text { razão }\end{array}$ & $\begin{array}{l}\text { ndiví } \\
(\mu \mathrm{g} \\
\text { erda } \\
\text { sistê }\end{array}$ & $\begin{array}{l}\text { estados } \\
\text { iil/mg) } \\
\mathrm{DL}_{50} \text { da } 1\end{array}$ & & & & \\
\hline
\end{tabular}

Os resultados obtidos no presente estudo confirmaram a presença de variabilidade genética nas populações de B. germanica no Brasil que conferem resistência a deltametrina, clorpirifós e fipronil, evidenciando a necessidade de implementação de estratégias de manejo da resistência para a preservação da vida útil desses produtos na área domissanitária. A utilização de mistura dos inseticidas deltametrina e clorpirifós, como estratégia de manejo da resistência nessas populações deve ser avaliada com cautela, pois os resultados mostraram resistência em diferentes intensidades aos 2 produtos. A utilização de mistura pode selecionar os indivíduos resistentes a esses 2 inseticidas (a ser discutido no Capítulo 5).

Se medidas de manejo da resistência de $B$. germanica a diferentes produtos não forem tomadas, o problema de controle desta praga poderá se agravar ainda mais, comprometendo novas moléculas em desenvolvimento. Trabalhos semelhantes devem 
ser conduzidos com outros produtos que estão sendo comercializados para o controle de B. germanica de modo a implementar estratégias efetivas de manejo da resistência. Sem dúvida, condições ótimas de sanitização devem ser incorporadas em um programa de manejo da resistência da barata alemã a inseticidas.

\subsection{Conclusões}

- O bioensaio de aplicação tópica é mais eficiente do que o bioensaio de contato tarsal para detectar a resistência em populações de Blattella germanica a deltametrina e clorpirifós.

- Há diferenças na suscetibilidade de populações de B. germanica testadas a deltametrina, clorpirifós e fipronil. 


\title{
4 CARACTERIZAÇÃO DA RESISTÊNCIA DE Blattella germanica (L., 1767) (Dictyoptera: Blattellidae) A DELTAMETRINA E CLORPIRIFÓS E RELAÇÕES DE RESISTÊNCIA CRUZADA COM FIPRONIL
}

\author{
Autor: Eloisa Salmeron \\ Orientador: Prof. Dr. Celso Omoto
}

Resumo

Os objetivos deste trabalho foram o de caracterizar a resistência de Blattella germanica (L.) aos inseticidas deltametrina e clorpirifós e avaliar as relações de resistência cruzada destes inseticidas com fipronil. $\mathrm{O}$ isolamento da resistência foi realizado em condições de laboratório com deltametrina e clorpirifós a partir de populações coletadas no campo. Três ciclos de pressão de seleção foram realizados para a obtenção das linhagens Deltametrina-R e Clorpirifós-R. A DL50 estimada para deltametrina na linhagem suscetível (SUS) foi de 0,24 (IC 95\% 0,18 - 0,31) e na linhagem Deltametrina-R de 10,26 (IC 95\% 7,28 - 14,17) $\mu \mathrm{g}$ deltametrina/mg. Para clorpirifós, a DL ${ }_{50}$ estimada para a linhagem SUS foi de 4,16 (IC 95\% 2,80 - 5,33) e para a linhagem Clorpirifós-R foi de 24,98 (IC 95\% 20,90 - 30,28) $\mu \mathrm{g}$ clorpirifós/mg. Portanto, as razões de resistência foram de aproximadamente 43 e 6 vezes para deltametrina e clorpirifós, respectivamente. A resistência de $B$. germanica a deltametrina foi instável, ou seja, houve uma redução significativa na freqüência de resistência na ausência de pressão de seleção. Uma baixa intensidade de resistência cruzada (aproximadamente 2 vezes) foi verificada entre fipronil e os inseticidas deltametrina e clorpirifós. Sendo assim, o fipronil mostrou ser viável como opção de controle em programas de manejo da resistência de $B$. germanica a deltametrina e clorpirifós. 


\title{
CHARACTERIZATION OF DELTAMETHRIN AND CHLORPYIRIFOS RESISTANCE IN Blattella germanica (L., 1767) (Dictyoptera: Blattellidae) AND CROSS-RESISTANCE RELATIONSHIPS TO FIPRONIL
}

\author{
Author: Eloisa Salmeron \\ Adviser: Prof. Dr. Celso Omoto
}

\section{Summary}

The objectives of this study were to characterize the resistance of Blattella germanica (L.) to deltamethrin and chlorpyrifos and to evaluate their cross-resistance relationships to fipronil. The isolation of resistance was done under laboratory conditions from field-collected populations. Three cycles of selection pressure with deltamethrin and chlorpyrifos were conducted to obtain the Deltamethrin- $R$ and Chlorpyrifos-R strains. The estimated $\mathrm{LD}_{50}$ for the susceptible (SUS) strain was 0.24 (IC $95 \% 0.18$ - 0.31) and for Deltamethrin-R strain was 10.26 (IC 95\% $7.28-14.17$ ) $\mu \mathrm{g}$ deltametrina/mg. For chlorpyrifos, $\mathrm{LD}_{50}$ for the SUS strain was 4.16 (IC 95\% $2.80-$ 5.33) and for Chlorpyrifos-R strain was 24.98 (IC 95\% 20.90 - 30.28) $\mu \mathrm{g}$ chlorpyrifos/mg. Therefore, the resistance ratios were approximately 43 and 6-fold to deltamethrin and chlorpyrifos, respectively. The resistance of $B$. germanica to deltamethrin was unstable, that is, a significant reduction in the frequency of resistance was detected under absence of selection pressure. A low intensity of cross-resistance (approximately 2-fold) was observed between fipronil and the insecticides deltamethrin and chlorpyrifos. Thus, fipronil can be used as a good candidate in resistance management programs of $B$. germanica to deltamethrin and chlorpyrifos. 


\subsection{Introdução}

A barata alemã Blattella germanica (L., 1767) (Dictyoptera: Blattellidae) é a principal espécie de barata domissanitária e o seu controle tem sido realizado principalmente com o uso de inseticidas. Sendo assim, a barata alemã tem desenvolvido resistência a quase todos os inseticidas utilizados no seu controle, principalmente aos do grupo dos organofosforados e piretróides (Cochran, 1989; Lee et al., 1996; Lin et al., 2000; Milio et al., 1987; Rust \& Reierson, 1991; Scott et al., 1990).

A resistência de $B$. germanica a organofosforados foi inicialmente documentada para diazinon em Kentucky (EUA) em 1961 (Georghiou \& Lagunes-Tejeda, 1991). O primeiro caso de resistência de $B$. germanica ao clorpirifós, um inseticida largamente utilizado em tratamentos domissanitários foi detectado pela Organização Mundial de Saúde (OMS) em 1980 no Canadá (Georghiou \& Lagunes-Tejeda, 1991). Posteriormente, a resistência a esse inseticida foi confirmada também em outros países com razões de resistência variando de 1,4 a 58 vezes (Cochran, 1989; Hemingway et al., 1993a; Milio et al., 1987; Rust \& Reierson, 1991; Schal, 1988; Scott et al., 1990), porém na grande maioria dos casos as intensidades de resistência a clorpirifós têm sido baixas e geralmente inferiores a 5 vezes (Cochran, 1989).

A resistência a piretróides também tem se tornado um problema sério em $B$. germanica (Ebbett \& Cochran, 1997). O primeiro caso de resistência de B. germanica a um inseticida piretróide foi documentado na antiga União Soviética em 1979 para tetrametrina (Georghiou \& Lagunes-Tejeda, 1991). Outros casos de resistência a piretróides foram detectados em seguida, como por exemplo para cipermetrina (Huang et al., 1999; Lin et al., 2000), lambdacialotrina (Ladonni, 1997; Valles, 1999), deltametrina (Huang et al., 1999; Lin et al., 2000) etc. As intensidades de resistência a piretróides têm atingido valores superiores a 100 vezes (Cochran, 1989).

Muitas populações de $B$. germanica têm desenvolvido resistência a mais de um inseticida através da resistência cruzada ou resistência múltipla (Cochran, 1987b) resultando assim em maiores dificuldades no seu controle. A resistência cruzada é também um problema potencial que pode limitar a efetividade de alguns novos 
inseticidas, pois a resistência a um inseticida em $B$. germanica pode ser acompanhada por resistência cruzada a produtos que ainda não foram lançados no mercado (Cochran, 1987b).

Apesar de inúmeros trabalhos de caracterização da resistência de B. germanica a inseticidas no âmbito mundial, pesquisas nesta área ainda são carentes no Brasil. Sendo assim, a partir de populações coletadas nas cidades do Rio de Janeiro e São Paulo foram realizados estudos para caracterizar a resistência de $B$. germanica aos inseticidas deltametrina e clorpirifós que são comumente utilizados isoladamente ou em mistura; avaliar a dinâmica da resistência de $B$. germanica a deltametrina para verificar se a resistência é instável na ausência da pressão de seleção; e posteriormente avaliar as relações de resistência cruzada entre fipronil, um inseticida lançado recentemente para o controle de B. germanica, e os inseticidas deltametrina e clorpirifós. Essas informações servirão de base para a implementação de programas de manejo da resistência de $B$. germanica a inseticidas no Brasil.

\subsection{Material e Métodos}

O trabalho foi realizado no laboratório de Resistência de Artrópodes a Pesticidas no Setor de Entomologia do Departamento de Entomologia, Fitopatologia e Zoologia Agrícola da Escola Superior de Agricultura “Luiz de Queiroz”, Universidade de São Paulo, em Piracicaba, SP.

Nesse estudo, a linhagem suscetível (SUS) de Blattella germanica a inseticidas foi obtida da Bioagri Laboratórios Ltda., em Piracicaba. Essa linhagem era mantida em laboratório por mais de 10 anos sem nunca ter recebido qualquer tratamento com inseticida. As caracterizações de resistência a deltametrina e clorpirifós foram realizadas a partir de populações de B. germanica coletadas nas cidades do Rio de Janeiro, RJ (populações identificadas como RJ-1 e RJ-2) e de São Paulo, SP (populações identificadas como SP-1 e SP-2). Falhas no controle com o uso de inseticidas haviam sido reportadas freqüentemente nessas populações de campo. A população RJ-1 foi coletada em abril de 1993 num refeitório industrial, RJ-2 coletada em outubro de 1996 
num supermercado, SP-1 coletada em setembro de 1997 num refeitório industrial e SP-2 coletada numa residência em janeiro de 1998. Os procedimentos de coleta e criação de B. germanica no laboratório estão descritos no Capítulo 3.

\subsubsection{Caracterização da resistência de Blattella germanica a deltametrina e clorpirifós}

As linhas básicas de suscetibilidade de B. germanica aos inseticidas deltametrina e clorpirifós foram obtidas mediante a caracterização toxicológica de baratas (machos adultos) da linhagem SUS a esses inseticidas por meio de bioensaio de aplicação tópica. Foram utilizados produtos técnicos de deltametrina $(98,5 \%$ de pureza, Aventis Environmental Science) e clorpirifós (97\% de pureza, Dow AgroSciences Industrial Ltda.) para os testes. O bioensaio consistiu na aplicação individual de $1 \mu 1$ da solução do inseticida técnico diluído em acetona na face ventral no $1^{\circ}$ segmento abdominal (Lee et al., 1996; Valles \& Yu, 1996) por meio do uso de uma microseringa de vidro de $1 \mathrm{ml}$ acoplada a um microaplicador automático (modelo Arnold LV6 da Burkard Manufacturing Co. Ltda.). Foram testadas 6 a 8 concentrações que proporcionaram mortalidades entre 5 e 99\%, utilizando-se aproximadamente 80 indivíduos para cada concentração do inseticida. Após a aplicação do inseticida, as baratas foram colocadas em recipientes plásticos (10 baratas/recipiente) de $500 \mathrm{ml}$ contendo algodão umedecido com água e alimento (ração para cachorro). Os bioensaios foram mantidos em uma câmara climatizada regulada à temperatura de $28 \pm 1^{\circ} \mathrm{C}$, umidade relativa de $55 \pm 5 \%$ e fotofase de 12 h (Lee et al., 1996). A avaliação da mortalidade foi feita com 48 h após a aplicação do inseticida, considerando-se como resposta, as baratas incapazes de se locomoverem normalmente e que apresentavam evidências de paralisia ou tombamento.

Para o isolamento e caracterização da resistência de $B$. germanica a deltametrina e clorpirifós, a população RJ-1 foi submetida à pressão de seleção com deltametrina e a população RJ-2 com clorpirifós. Em cada população foram feitas seleções para resistência com machos, fêmeas e ninfas por 3 ciclos utilizando-se a 
concentração de $320 \mu \mathrm{g}$ de deltametrina/ml de acetona e $1000 \mu \mathrm{g}$ de clorpirifós/ml de acetona por meio de bioensaio de aplicação tópica. Essas concentrações foram determinadas através de testes preliminares, baseados na $\mathrm{CL}_{99}$ de cada inseticida para a linhagem SUS. As baratas sobreviventes após cada seleção serviram para a formação de uma nova população. Após 3 ciclos de seleção com deltametrina, a população obtida a partir dos sobreviventes da última seleção da população RJ-1 foi denominada Deltametrina-R, e após a última seleção com clorpirifós a partir da população RJ-2, a população obtida foi denominada Clorpirifós-R.

Para avaliar a resposta à pressão de seleção, após cada ciclo de seleção, as populações obtidas foram submetidas aos bioensaios de aplicação tópica para estimativa da $\mathrm{CL}_{50}$ pela análise de Probit (LeOra Software, 1987). Em seguida os dados foram transformados em $\mathrm{DL}_{50}$ dividindo-se a $\mathrm{CL}_{50}$ pelo peso médio dos machos $(\mathrm{mg})$ da linhagem correspondente. Posteriormente, foram estimadas a resposta à pressão de seleção (quociente da $\mathrm{DL}_{50}$ da população selecionada pela $\mathrm{DL}_{50}$ da população original anterior à seleção) e a razão de resistência (quociente da DL $_{50}$ população em estudo pela $\mathrm{DL}_{50}$ linhagem suscetível). Após a obtenção das curvas de dose-resposta das populações de $B$. germanica para cada inseticida, doses diagnósticas foram definidas para programas de monitoramento da resistência.

\subsubsection{Dinâmica da resistência de Blattella germanica a deltametrina}

A dinâmica da resistência de $B$. germanica a deltametrina foi realizada mediante acompanhamento da suscetibilidade a deltametrina nas populações SP-1 e SP2 mantidas em laboratório na ausência de pressão de seleção. A suscetibilidade dessas 2 populações para deltametrina foi avaliada nos meses de Junho de 1999, Maio de 2000 e Outubro de 2000. Os mesmos procedimentos de bioensaio e análise dos dados descritos anteriormente foram utilizados para estimar a $\mathrm{CL}_{50}$ em cada época de avaliação para as 2 populações. 


\subsubsection{Relações de resistência cruzada com o inseticida fipronil}

Para estabelecer as relações de resistência cruzada entre fipronil e os inseticidas deltametrina e clorpirifós, as linhagens SUS, Deltametrina-R e Clorpirifós-R foram testadas com fipronil. As caracterizações toxicológicas dessas populações para o fipronil foram realizadas por meio de bioensaio de aplicação tópica com o produto técnico (89\% de pureza, Aventis Environmental Science). Foram adotados os mesmos procedimentos de bioensaio descritos anteriormente.

Os dados de mortalidade de cada linhagem com o fipronil foram submetidos à análise de Probit pelo programa estatístico POLO-PC (LeOra Software, 1987) para estimar a $\mathrm{CL}_{50}$. Posteriormente, os resultados foram expressos em $\mathrm{DL}_{50}$. A presença ou não de resistência cruzada foi avaliada pelo teste de igualdade de respostas ao fipronil entre a linhagem SUS e as duas linhagens resistentes (Deltametrina-R e Clorpirifós-R) (LeOra Software, 1987) e pela avaliação da sobreposição ou não do intervalo de confiança (IC) das DL $_{50}$ estimadas para as linhagens resistentes em estudo e a da linhagem SUS. A sobreposição do IC foi interpretada como ausência de resistência cruzada. O nível de significância dos testes foi de $\alpha=0,05$.

\subsection{Resultados e Discussão}

\subsubsection{Caracterização da resistência de Blattella germanica a deltametrina e clorpirifós}

Foi verificada uma resposta significativa da população RJ-1 à pressão de seleção com deltametrina (Tabela 10). A DL50 da população RJ-1 (antes da seleção) foi de $2,58 \mu \mathrm{g}$ deltametrina/mg (IC 95\% 1,67 - 3,66). Após 3 ciclos de seleção, a $\mathrm{DL}_{50}$ atingiu valores de 10,26 $\mu \mathrm{g}$ deltametrina/mg (IC 95\% 7,28 - 14,17) na linhagem Deltametrina-R com 570 insetos testados. Portanto, a resposta à pressão de seleção foi de aproximadamente 4 vezes, baseado na estimativa da $\mathrm{DL}_{50}$. A $\mathrm{DL}_{50}$ estimada para o inseticida deltametrina na linhagem suscetível (SUS) foi de 0,24 (IC 95\% 0,18 - 0,31) 
$\mu \mathrm{g}$ deltametrina/mg com 740 insetos testados. A intensidade de resistência de $B$. germanica a deltametrina foi de aproximadamente 43 vezes (Tabela 10 e Figura 6). Houve um aumento significativo no coeficiente angular da curva de regressão obtida a partir da análise de Probit a cada ciclo de seleção, o que evidencia um aumento na homogeneidade da população por meio da eliminação de indivíduos suscetíveis da população RJ-1.

Tabela 10. Respostas à pressão de seleção da população RJ-1 de Blattella germanica ao inseticida deltametrina.

\begin{tabular}{|c|c|c|c|c|c|c|}
\hline $\begin{array}{l}\text { Linhagem/ } \\
\text { População }\end{array}$ & $\mathbf{n}^{\mathbf{a}}$ & $\begin{array}{c}\mathrm{DL}_{50}^{b} \\
(\mathrm{IC} 95 \%)\end{array}$ & $\begin{array}{l}\text { Coeficiente } \\
\text { angular } \\
( \pm \text { dp) }\end{array}$ & $\chi^{2}$ & gl $^{c}$ & $\mathbf{R R}^{\mathbf{d}}$ \\
\hline SUS & 740 & $\begin{array}{c}0,24 \\
(0,18-0,31)\end{array}$ & $\begin{array}{c}2,83 \\
( \pm 0,17)\end{array}$ & 12,34 & 4 & - \\
\hline RJ-1 & 880 & $\begin{array}{c}2,58 \\
(1,67-3,66)\end{array}$ & $\begin{array}{c}1,62 \\
( \pm 0,11)\end{array}$ & 20,63 & 6 & 10,75 \\
\hline RJ-1 I ${ }^{\mathrm{e}}$ & 957 & $\begin{array}{c}6,42 \\
(4,79-5,22)\end{array}$ & $\begin{array}{c}1,74 \\
( \pm 0,11)\end{array}$ & 18,55 & 7 & 26,75 \\
\hline RJ-1 II f & 1080 & $\begin{array}{c}8,72 \\
(5,55-12,48)\end{array}$ & $\begin{array}{c}1,75 \\
( \pm 0,10)\end{array}$ & 66,21 & 10 & 36,33 \\
\hline Deltametrina- $\mathbf{R}^{\mathrm{g}}$ & 570 & $\begin{array}{c}10,26 \\
(7,28-14,17)\end{array}$ & $\begin{array}{c}2,35 \\
( \pm 0,19)\end{array}$ & 25,14 & 7 & 42,75 \\
\hline
\end{tabular}

${ }^{\mathrm{a}} \mathrm{n}=$ número de insetos testados

${ }^{\mathrm{b}}$ dose letal média- $\mu \mathrm{g}$ deltametrina/mg do inseto

${ }^{\mathrm{c}} \mathrm{gl}=$ graus de liberdade

${ }^{\mathrm{d}} \mathrm{RR}=$ razão de resistência ( $\mathrm{DL}_{50}$ da população em estudo/ $\mathrm{DL}_{50}$ da linhagem suscetível-SUS)

e após um ciclo de seleção

${ }^{\mathrm{f}}$ após 2 ciclos de seleção

${ }^{\mathrm{g}}$ após 3 ciclos de seleção 


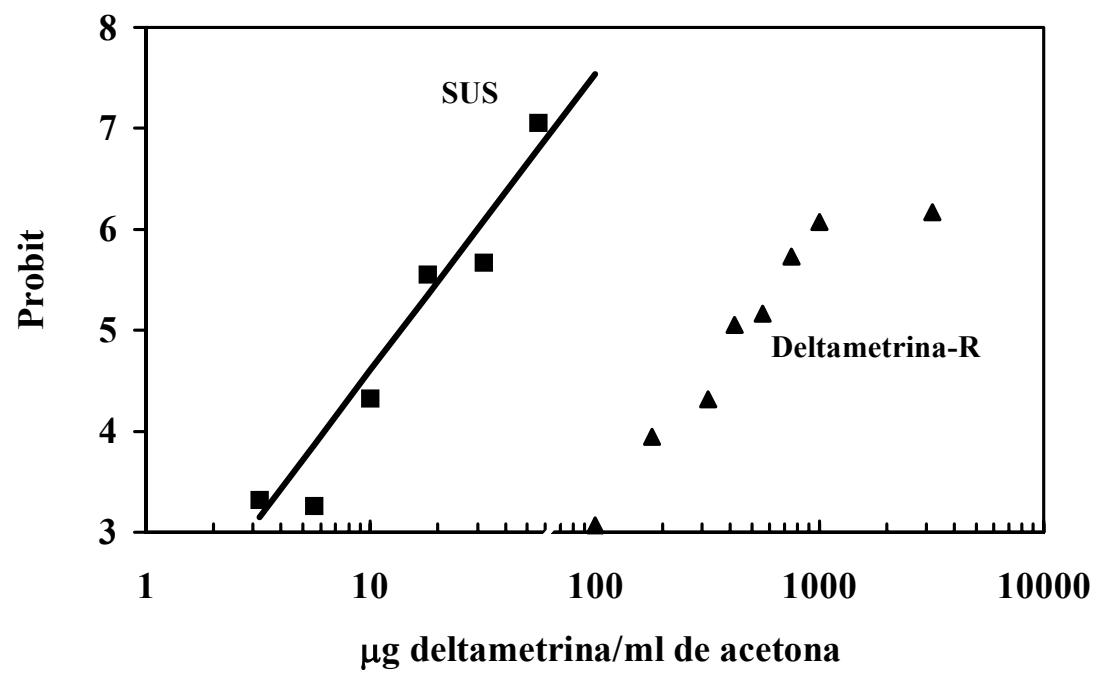

Figura 6 - Linhas de concentração-resposta das linhagens suscetível (SUS) e resistente (Deltametrina-R) a deltametrina por meio de bioensaio de aplicação tópica.

Não foi verificada resposta à pressão de seleção da população RJ-2 com clorpirifós (Tabela 11). A DL 50 da população RJ-2 (antes da seleção) foi de 27,54 $\mu \mathrm{g}$ clorpirifós/mg (IC 95\% 24,80 - 30,50) e após 3 ciclos de seleção, a DL 50 foi de 24,98 $\mu \mathrm{g}$ clorpirifós/mg (IC 95\% 20,90 - 30,28). Não houve alteração no coeficiente angular da curva de regressão obtida a partir da análise de Probit a cada ciclo de seleção, o que comprova a ausência de reposta à pressão de seleção com clorpirifós na concentração testada em laboratório. No entanto, a população obtida após 3 ciclos de seleção com clorpirifós foi denominada de linhagem Clorpirifós-R.

Mediante comparação da suscetibilidade ao clorpirifós das linhagens SUS e Clorpirifós-R, foi obtida uma intensidade de resistência de aproximadamente 6 vezes (Tabela 11 e Figura 7). A DL ${ }_{50}$ estimada na linhagem SUS foi de 4,16 (IC 95\% 2,80 $5,33) \mu \mathrm{g}$ clorpirifós/mg com 520 insetos testados e na linhagem Clorpirifós-R a $\mathrm{DL}_{50}$ foi de 24,98 (IC 95\% 20,90 - 30,28) $\mu$ g clorpirifós/mg com 574 insetos testados. 
Tabela 11. Respostas à pressão de seleção da população RJ-2 de Blattella germanica ao inseticida clorpirifós.

\begin{tabular}{|c|c|c|c|c|c|c|}
\hline $\begin{array}{l}\text { Linhagem/ } \\
\text { População }\end{array}$ & $\mathbf{n}^{\mathrm{a}}$ & $\begin{array}{c}D_{50}^{b} \\
(\text { IC 95\%) }\end{array}$ & $\begin{array}{l}\text { Coeficiente } \\
\text { angular } \\
( \pm \text { dp) }\end{array}$ & $\chi^{2}$ & $\mathrm{gl}^{\mathrm{c}}$ & $\mathbf{R}^{\mathbf{d}}$ \\
\hline SUS & 520 & $\begin{array}{c}4,16 \\
(2,80-5,33)\end{array}$ & $\begin{array}{c}4,71 \\
( \pm 0,46)\end{array}$ & 13,19 & 4 & - \\
\hline RJ-2 & 707 & $\begin{array}{c}27,54 \\
(24,80-30,50)\end{array}$ & $\begin{array}{c}3,29 \\
( \pm 0,21)\end{array}$ & 8,89 & 8 & 6,62 \\
\hline RJ-2 I ${ }^{\mathrm{e}}$ & 619 & $\begin{array}{c}27,43 \\
(25,17-29,98)\end{array}$ & $\begin{array}{c}3,21 \\
( \pm 0,23)\end{array}$ & 3,07 & 6 & 6,59 \\
\hline RJ-2 II ${ }^{f}$ & 690 & $\begin{array}{c}24,72 \\
(21,82-27,74)\end{array}$ & $\begin{array}{c}3,25 \\
( \pm 0,22)\end{array}$ & 8,80 & 7 & 5,94 \\
\hline Clorpirifós-R ${ }^{\text {g }}$ & 574 & $\begin{array}{c}24,98 \\
(20,90-30,28)\end{array}$ & $\begin{array}{c}3,28 \\
( \pm 0,29)\end{array}$ & 9,80 & 5 & 6,00 \\
\hline
\end{tabular}

${ }^{\mathrm{a}} \mathrm{n}=$ número de insetos testados

${ }^{\mathrm{b}}$ dose letal média- $\mu \mathrm{g}$ clorpirifós/mg do inseto

${ }^{\mathrm{c}} \mathrm{gl}=$ graus de liberdade

${ }^{\mathrm{d}} \mathrm{RR}=$ razão de resistência ( $\mathrm{DL}_{50}$ da população em estudo/ $\mathrm{DL}_{50}$ da linhagem suscetível-SUS)

e após um ciclo de seleção

f após 2 ciclos de seleção

g após 3 ciclos de seleção 


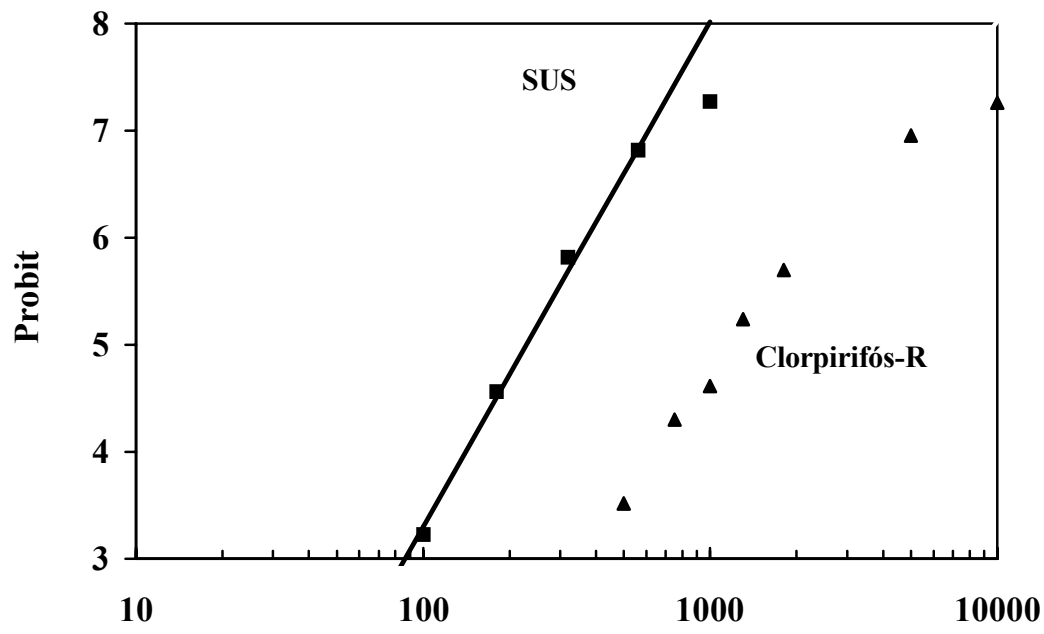

$\mu \mathrm{g}$ clorpirifós/ml de acetona

Figura 7 - Linhas de concentração-resposta das linhagens suscetível (SUS) e resistente (Clorpirifós-R) ao clorpirifós por meio de bioensaio de aplicação tópica.

A concentração de $100 \mu \mathrm{g}$ deltametrina/ml de acetona pode se ser usada como uma concentração diagnóstica para trabalhos de monitoramento da resistência a deltametrina (Figura 6). Nessa concentração, a mortalidade média da linhagem SUS é de $100,00 \%$. Por outro lado, a mortalidade da linhagem Deltametrina-R é de apenas 2,78\%. Devido à sobreposição das linhas de dose-resposta ao clorpirifós para as linhagens SUS e Clorpirifós-R (Figura 7), não foi possível definir uma única concentração diagnóstica para o monitoramento da resistência. Nesse caso, sugere-se o uso de várias concentrações diagnósticas (por exemplo: 320, 1000 e $1300 \mu$ g clorpirifós/ml de acetona) para avaliar a suscetibilidade de populações de $B$. germanica a esse inseticida. A vantagem da utilização do bioensaio de concentração diagnóstica em relação à estimativa da $\mathrm{DL}_{50}$ num programa de manejo da resistência é que através da concentração diagnóstica pode-se detectar o problema da resistência ainda no início da evolução. Com a estimativa da $\mathrm{DL}_{50}$, a resistência pode ser detectada somente quando a freqüência da resistência já está relativamente alta (Roush \& Miller, 1986). 
O alto nível de resistência a deltametrina encontrado no presente estudo reflete o intenso uso deste produto no controle de B. germanica no Brasil. Possivelmente, os resultados obtidos podem ser explicados também devido a inseticidas anteriormente utilizados, como o DDT que apresenta o mesmo mecanismo de ação dos piretróides. Vários estudos têm comprovado a presença de resistência cruzada entre piretróides e DDT através do mecanismo de resistência do tipo $k d r$ (insensibilidade do sítio de ação) (Siegfried \& Scott, 1992). A forma exata na qual esse mecanismo funciona em baratas é desconhecido, mas em outros insetos tem sido sugerido que modificações nos canais de sódio conferem menor suscetibilidade aos piretróides (Cochran, 1995).

Um aspecto importante da resistência de B. germanica a organofosforados é que níveis de resistência extremamente altos não têm sido observados. A baixa intensidade de resistência ao clorpirifós pode ser devido aos mecanismos de resistência envolvidos (Cochran, 1995). A resistência ao clorpirifós parece ser controlada de maneira mais complexa, com 2 ou mais genes envolvidos (Cochran, 1989; Milio et al., 1987). Um dos mecanismos de resistência identificados para o clorpirifós indica que diferentes formas de enzimas oxidativa e hidrolítica são responsáveis pela resistência (Siegfried \& Scott, 1992).

\subsubsection{Dinâmica da resistência de Blattella germanica a deltametrina}

A resistência de $B$. germanica a deltametrina foi instável, ou seja, houve uma redução significativa na freqüência de resistência na ausência de pressão de seleção (Tabela 12 e Figura 8). A DL 50 da população SP-1 reduziu de 15,94 $\mu$ g deltametrina/mg (IC 95\% 10,92 - 28,07) em abril/junho de 1999 para 0,63 (IC 95\% 0,10 - 1,21) em outubro/novembro de 2000. Para a população SP-2, essa redução foi de 25,83 $\mu \mathrm{g}$ deltametrina/mg (IC 95\% -) em junho de 1999 para 5,46 (IC 95\% 4,12 - 7,03) em outubro de 2000. Como as populações de B. germanica foram mantidas em recipientes de vidro fechadas com tela tipo voil, a redução na suscetibilidade não pode ser explicada pela imigração de indivíduos suscetíveis na população. Portanto, os resultados obtidos

podem ser explicados pela presença de um custo adaptativo de indivíduos resistentes na 
ausência de pressão de seleção. Esse menor valor adaptativo dos indivíduos resistentes pode estar associado a uma menor viabilidade total, menor fecundidade, maior tempo para o desenvolvimento etc, do que os indivíduos suscetíveis (Georghiou, 1972; Roush \& Daly, 1990 e Roush \& McKenzie, 1987). Estudos conduzidos por Cochran (1993) também mostraram que na ausência de pressão de seleção, a resistência a piretróides em B. germanica sofreu uma redução significativa na resistência em aproximadamente 15 gerações $(\approx 2$ anos).

Tabela 12. Mudanças na suscetibilidade das populações SP-1 e SP-2 de Blattella germanica ao inseticida deltametrina no decorrer do tempo na ausência de pressão de seleção.

\begin{tabular}{|c|c|c|c|c|c|c|c|}
\hline População & $\begin{array}{c}\text { Data } \\
\text { de } \\
\text { Coleta }\end{array}$ & $\begin{array}{c}\text { Data } \\
\text { do } \\
\text { Bioensaio }\end{array}$ & $\mathbf{n}^{\mathbf{a}}$ & $\begin{array}{c}\mathrm{DL}_{50}{ }^{b} \\
(\mathrm{IC} 95 \%)\end{array}$ & $\begin{array}{c}\text { Coeficiente } \\
\text { Angular } \\
( \pm \text { dp })\end{array}$ & $\chi^{2}$ & $\mathrm{gl}^{\mathrm{c}}$ \\
\hline \multirow{3}{*}{ SP-1 } & \multirow{3}{*}{ Set/97 } & Abr-Jun/99 & 330 & $\begin{array}{c}15,94 \\
(10,92-28,07)\end{array}$ & $\begin{array}{c}2,03 \\
( \pm 0,23)\end{array}$ & 5,13 & 3 \\
\hline & & Mar-Mai/00 & 280 & $\begin{array}{c}1,26 \\
(0,23-2,88)\end{array}$ & $\begin{array}{c}1,20 \\
( \pm 0,23)\end{array}$ & 3,58 & 7 \\
\hline & & Out-Nov/00 & 190 & $\begin{array}{c}0,63 \\
(0,10-1,21)\end{array}$ & $\begin{array}{c}1,52 \\
( \pm 0,39)\end{array}$ & 1,92 & 3 \\
\hline \multirow{3}{*}{ SP-2 } & \multirow{3}{*}{ Jan/98 } & Jun/99 & 160 & $\begin{array}{c}25,83 \\
(-)\end{array}$ & $\begin{array}{c}1,95 \\
( \pm 0,28)\end{array}$ & 6,94 & 2 \\
\hline & & Abr-Mai/00 & 185 & $\begin{array}{c}6,41 \\
(4,45-9,10)\end{array}$ & $\begin{array}{c}1,58 \\
( \pm 0,23)\end{array}$ & 2,11 & 4 \\
\hline & & Out/00 & 240 & $\begin{array}{c}5,46 \\
(4,12-7,03)\end{array}$ & $\begin{array}{c}1,76 \\
( \pm 0,21)\end{array}$ & 0,97 & 4 \\
\hline
\end{tabular}




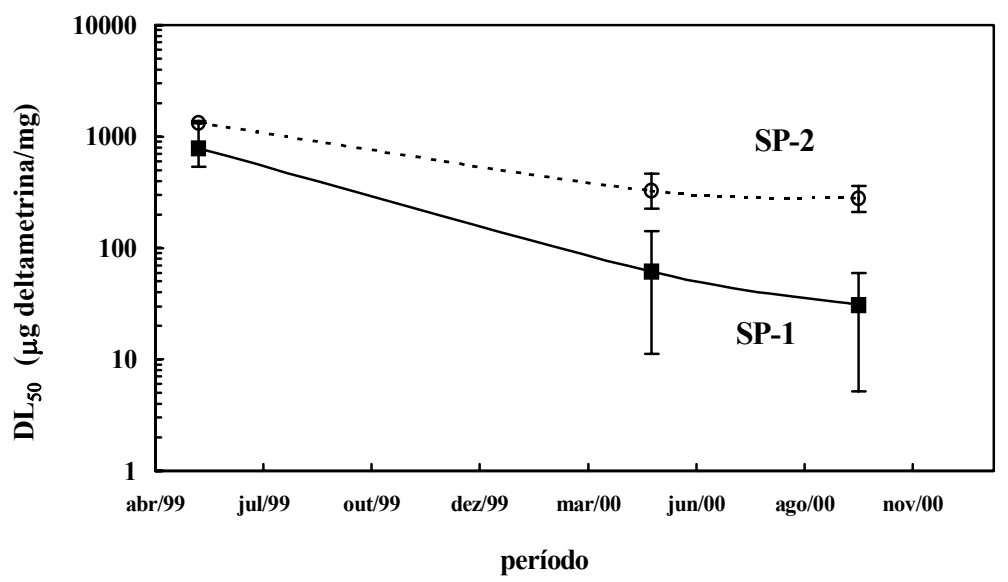

Figura 8 - Suscetibilidade das populações SP-1 e SP-2 de Blattella germanica ao inseticida deltametrina no decorrer do tempo na ausência de pressão de seleção.

Como foi observado através dos dados obtidos neste trabalho, o restabelecimento da suscetibilidade pode ser observado em situações em que a deltametrina deixa de ser utilizada por um certo período de tempo. Dessa forma, essa instabilidade da resistência pode ser explorada dentro de um programa de manejo da resistência através do sistema de rotação de produtos no controle de B. germanica.

\subsubsection{Relações de resistência cruzada com o inseticida fipronil}

Foi observada uma baixa intensidade de resistência cruzada entre o fipronil e os inseticidas deltametrina (Figura 9) e clorpirifós (Figura 10), baseado na sobreposição dos intervalos de confiança das $\mathrm{DL}_{50}$ estimadas (Tabela 13). Para a deltametrina, houve a sobreposição do valor do limite superior do IC para a $\mathrm{DL}_{50}$ da linhagem SUS e o limite inferior do IC da linhagem Deltametrina-R. Estatisticamente não há diferenças na resposta para fipronil entre essas duas linhagens. Segundo Scott \& Wen (1997), a resistência cruzada é um problema sério somente para casos em que os valores da razão de resistência são superiores a 4,0. 
Pelo teste de igualdade das linhas de regressão estimadas através da análise de Probit, verificou-se que as respostas das linhagens Deltametrina-R $\left(\chi^{2}=96,93\right.$; g.l. $=2$; $\mathrm{P}<0,005)$ e Clorpirifós-R $\left(\chi^{2}=141,12 ;\right.$ g.l. $\left.=2 ; \mathrm{P}<0,005\right)$ não são as mesmas em relação à resposta da linhagem SUS ao fipronil. Os valores dos coeficientes angulares para as linhagens resistentes (Deltametrina-R e Clorpirifós-R) são significativamente inferiores ao da linhagem SUS, o que evidencia uma maior heterogeneidade das linhagens resistentes ao fipronil. Provavelmente algum mecanismo de resistência presente nas linhagens Deltametrina- $\mathrm{R}$ e Clorpirifós- $\mathrm{R}$ também confere resistência ao fipronil. Para clarificar os resultados, seria necessário conduzir os trabalhos com linhagens isogênicas e realizar estudos de pressão de seleção dessas linhagens com fipronil. 
Tabela 13. Respostas de dose-mortalidade das linhagens suscetível (SUS), DeltametrinaR e Clorpirifós-R de Blattella germanica quando testadas com o inseticida fipronil.

\begin{tabular}{|c|c|c|c|c|c|c|}
\hline \multirow[b]{2}{*}{ Linhagem } & \multicolumn{6}{|c|}{ Coeficiente } \\
\hline & $n^{a}$ & $\begin{array}{c}D_{50}^{b} \\
(\text { IC 95\%) }\end{array}$ & $\begin{array}{c}\text { Angular } \\
\text { ( } \pm \text { ep) }\end{array}$ & $\chi^{2}$ & $\mathrm{gl}^{\mathrm{c}}$ & $\mathbf{R R}^{\mathbf{d}}$ \\
\hline SUS & 520 & $\begin{array}{c}0,033 \\
(0,023-0,043)\end{array}$ & $6,03( \pm 0,45)$ & 14,77 & 3 & - \\
\hline Deltametrina-R & 610 & $\begin{array}{c}0,068 \\
(0,043-0,12)\end{array}$ & $3,12( \pm 0,25)$ & 76,64 & 7 & 2,06 \\
\hline Clorpirifós-R & 515 & $\begin{array}{c}0,067 \\
(0,061-0,075)\end{array}$ & $4,41( \pm 0,35)$ & 10,85 & 7 & 2,03 \\
\hline
\end{tabular}

a $\mathrm{n}=$ número de insetos testados

${ }^{\mathrm{b}}$ dose letal média ( $\mu \mathrm{g}$ fipronil $/ \mathrm{mg}$ )

c gl= graus de liberdade

d $\mathrm{RR}=$ razão de resistência ( $\mathrm{DL}_{50}$ população em estudo/DL ${ }_{50}$ linhagem SUS) 


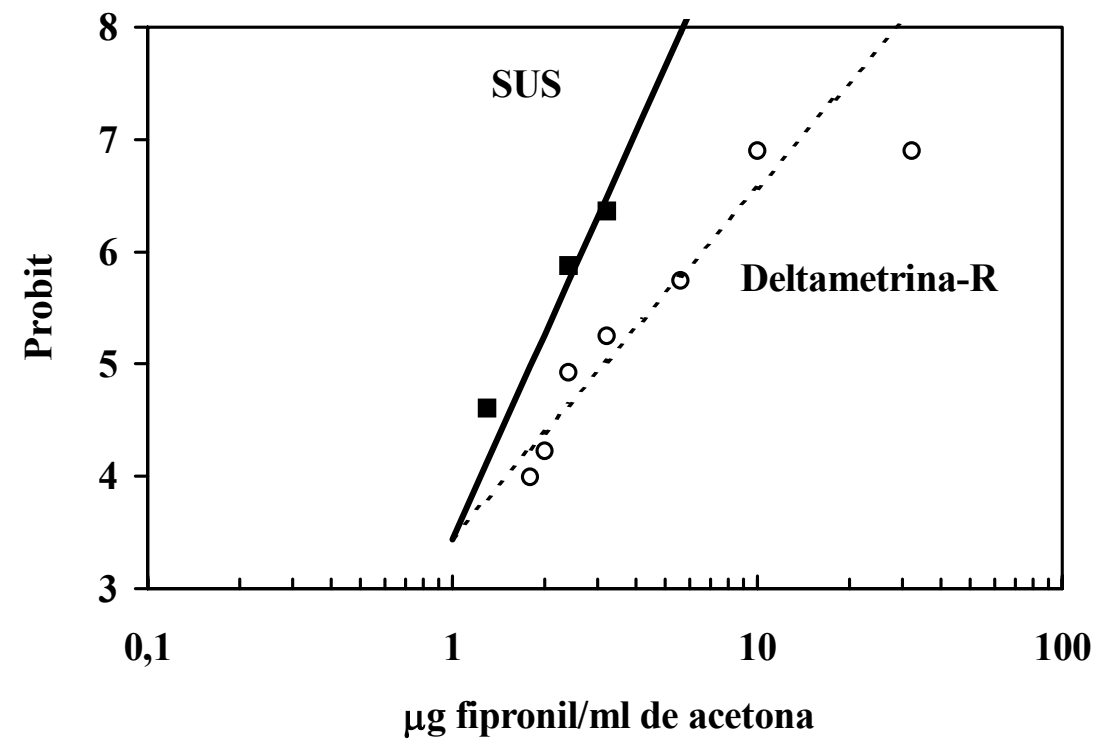

Figura 9 - Linhas de concentração-resposta das linhagens de Blattella germanica suscetível (SUS) (ロ) e resistente a deltametrina (Deltametrina-R) (O) quando testadas com o inseticida fipronil.

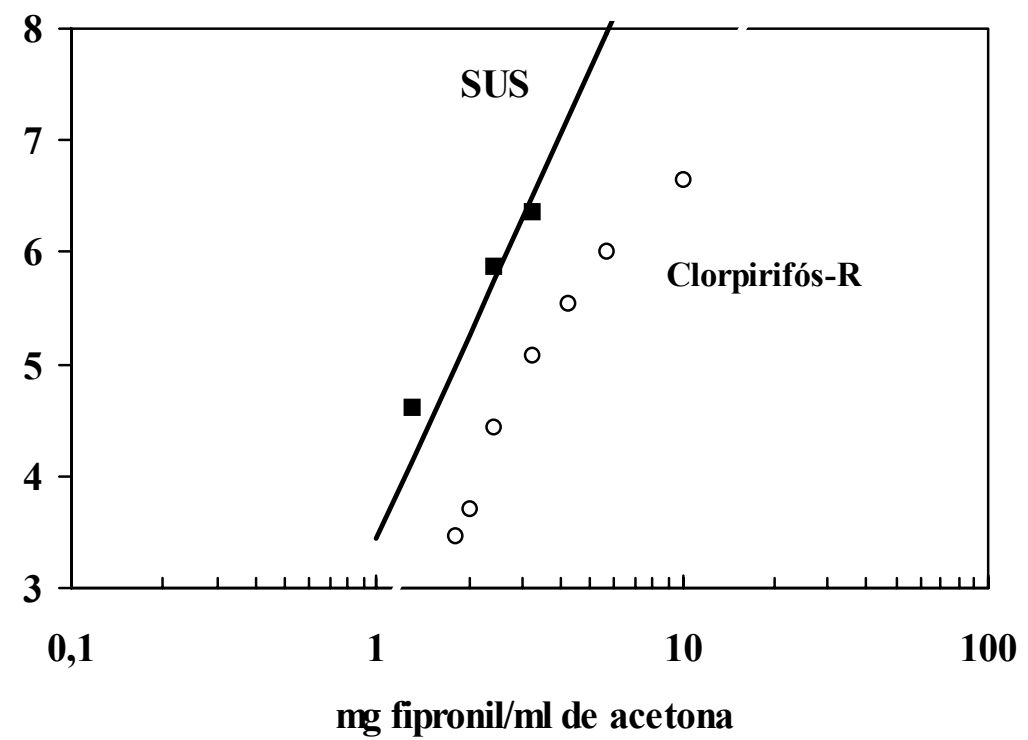

Figura 10 - Linhas de concentração-resposta das linhagens de Blattella germanica suscetível (SUS) (ロ) e resistente ao clorpirifós (Clorpirifós-R) (O) quando testadas com o inseticida fipronil. 
Uma possibilidade de resistência cruzada entre os inseticidas deltametrina e fipronil poderia ser devido ao mecanismo secundário de ação da deltametrina por meio da ação tóxica exercida pela interação com os canais de cloro mediados pelo sistema GABA (ácido gama-aminobutírico), que é o principal sítio de ação para o fipronil (Valles et al., 1997). Estudos realizados por Scott \& Wen (1997) mostraram que uma população de Musca domestica L. resistente a deltametrina (razão de resistência superior a 2000 vezes) apresentou resistência cruzada de 15 vezes com o inseticida fipronil.

A presença de resistência cruzada entre os produtos limita a escolha dos inseticidas disponíveis e a resistência múltipla impede o retorno a inseticidas previamente utilizados. Outros produtos como hidrametilona e imidacloprid, produtos mais recentes no mercado para o controle de baratas, também devem ser testados para resistência cruzada com os produtos atualmente utilizados, como alternativa de controle da barata alemã.

\subsection{Conclusões}

- As razões de resistência de Blattella germanica aos inseticidas deltametrina e clorpirifós foram de aproximadamente 43 e 6 vezes, respectivamente.

- A resistência de $B$. germanica a deltametrina foi instável na ausência de pressão seletiva.

- Baixa intensidade de resistência cruzada foi detectada entre fipronil e os inseticidas deltametrina e clorpirifós em B. germanica. 


\title{
5 MISTURA DE DELTAMETRINA E CLORPIRIFÓS NO MANEJO DA RESISTÊNCIA DE Blattella germanica (L.) (Dictyoptera: Blattellidae) A DELTAMETRINA
}

\author{
Autor: Eloisa Salmeron \\ Orientador: Prof. Dr. Celso Omoto
}

\section{Resumo}

A viabilidade do uso da mistura de deltametrina e clorpirifós no manejo da resistência de Blattella germanica (L.) a deltametrina foi avaliada no presente estudo. A avaliação da mistura foi realizada a partir de um bioensaio de contato tarsal com as linhagens suscetível e resistente de $B$. germanica a deltametrina. Os tratamentos testados foram (a) 12,5 mg deltametrina $/ \mathrm{m}^{2}$; (b) $240 \mathrm{mg}$ clorpirifós $/ \mathrm{m}^{2}$; (c) mistura de 12,5 mg deltametrina $+120 \mathrm{mg}$ clorpirifós $/ \mathrm{m}^{2}$; (d) mistura de $12,5 \mathrm{mg}$ deltametrina $+240 \mathrm{mg}$ clorpirifós $/ \mathrm{m}^{2}$ e (e) controle. A aplicação dos tratamentos foi realizada sobre azulejos. As infestações de baratas sobre os azulejos tratados foram realizadas com resíduos de 0 , $7,14,21,28,35$ e 42 dias de idade. A mistura proporcionou um melhor controle da linhagem suscetível do que os produtos utilizados isoladamente. No tratamento de mistura de $120 \mathrm{~g}$ de clorpirifós (metade da dose recomendada) com 12,5 mg deltametrina $/ \mathrm{m}^{2}$, a sobrevivência de indivíduos resistentes a deltametrina foi observada logo a partir de resíduos com 14 dias de idade, ao passo que com 240 g clorpirifós na mistura, a seleção a favor de indivíduos resistentes a deltametrina ocorreu somente a partir de resíduos com 42 dias de idade. Portanto, a mistura de deltametrina e clorpirifós nas doses atualmente recomendadas $\left(12,5 \mathrm{mg}\right.$ deltametrina $+120 \mathrm{mg}$ clorpirifós $\left./ \mathrm{m}^{2}\right)$ deve ser reavaliada para o manejo da resistência de $B$. germanica a deltametrina. 


\title{
MIXTURE OF DELTAMETHRIN AND CHLORPYRIFOS FOR MANAGING Blattella germanica (L.) (Dictyoptera: Blattellidae) RESISTANCE TO DELTAMETHRIN
}

\author{
Author: Eloisa Salmeron \\ Adviser: Prof. Dr. Celso Omoto
}

\section{Summary}

The viabilility of the use of deltamethrin and chlorpyrifos mixture for managing Blattella germanica (L.) resistance to deltamethrin was evaluated in this study. A residual tarsal-contact bioassay was tested on susceptible and resistant strains of $B$. germanica. The following treatments were evaluated: (a) $12.5 \mathrm{mg}$ deltamethrin $/ \mathrm{m}^{2}$; (b) $240 \mathrm{mg}$ chlorpyrifos $/ \mathrm{m}^{2}$; (c) mixture of $12.5 \mathrm{mg}$ deltamethrin $+120 \mathrm{mg}$ chlorpyrifos $/ \mathrm{m}^{2}$; (d) mixture of $12,5 \mathrm{mg}$ deltamethrin $+240 \mathrm{mg}$ chlorpyrifos $/ \mathrm{m}^{2}$ and (e) control. The application of the treatments was done on tiles. The infestations of German cockroaches on treated-tiles were done on $0,7,14,28,35$ and 42-day old residues. The use of mixtures gave better control of the susceptible strain than the use of the products by itself. In the mixture of $120 \mathrm{mg}$ of chlorpyrifos (half of the recommended rate) in 12.5 $\mathrm{mg}$ of deltamethrin $/ \mathrm{m}^{2}$, the discrimination of the strains was detected from 14-day old residues and with $240 \mathrm{mg}$ of chlorpyrifos in the mixture, the discrimination was possible only with 42-day old residues. Thus, the commercial recommended rates of deltamethrin and chlorpyrifos in the mixture $\left(12.5 \mathrm{mg}\right.$ deltamethrin $+120 \mathrm{mg}$ chlorpyrifos $\left./ \mathrm{m}^{2}\right)$ should be revaluated for managing $B$. germanica resistance to deltamethrin. 


\subsection{Introdução}

A mistura dos inseticidas deltametrina e clorpirifós tem sido muito utilizada no controle de Blattella germanica (L.) (Dictyoptera: Blattellidae). As principais razões têm sido devido ao excelente efeito de choque (knock-down) proporcionado pela deltametrina e ao efeito residual de clorpirifós. No entanto, dentro do contexto de manejo da resistência de pragas a pesticidas, o uso de misturas de produtos deve ser criteriosamente avaliado.

A recomendação da mistura de pesticidas para o manejo da resistência é baseada no princípio de que os indivíduos resistentes a um determinado produto serão controlados pelo outro componente da mistura, e vice-versa (Georghiou, 1983). Dentre as várias condições para o sucesso dessa estratégia devem ser consideradas a baixa freqüência de resistência para os dois componentes da mistura, padrão de herança da resistência recessiva para pelo menos um dos produtos, alta mortalidade da praga, presença de refúgio para indivíduos suscetíveis, persistência biológica semelhante para os dois componentes da mistura etc. (Mani, 1985; Roush, 1989; Tabashnik, 1989). Estas condições são raramente obedecidas na prática, levando à seleção de indivíduos resistentes aos 2 produtos simultaneamente.

Em algumas situações, o uso da mistura de produtos pode ser mais vantajoso do que o uso de produtos isolados para o controle de pragas, principalmente em situações onde ocorre sinergismo dos produtos em mistura (Stone et al., 1988). Esse sinergismo pode ocorrer, por exemplo, em situações onde um mecanismo de resistência a um determinado produto confere uma maior suscetibilidade a um outro produto. Por exemplo, um aumento na destoxificação metabólica por meio de monooxigenases dependentes do citocromo P-450 em linhagens resistentes de uma espécie a um piretróide pode conferir uma maior suscetibilidade a inseticidas fosforotioatos que são bioativados por meio deste mesmo grupo enzimático por dessulfuração (Matsumura, 1985). O sinergismo de fosforotioatos e piretróides tem sido explorado em alguns programas de controle de pragas, tais como Heliothis virescens (F.) (Plapp et al., 1990), Bemisia tabaci (Genn.) (Denholm et al., 1999), Musca domestica L. (MacDonald et al., 1983), Haematobia irritans (L.) (Byford et al., 1987) etc. 
Como a prática de uso da mistura de deltametrina e clorpirifós tem sido muito comum no controle de $B$. germanica nas nossas condições, o objetivo do presente estudo foi o de avaliar a viabilidade dessa mistura nas doses recomendadas atualmente no manejo de resistência de $B$. germanica a deltametrina.

\subsection{Material e Métodos}

Este experimento foi conduzido no laboratório de Resistência de Artrópodes a Pesticidas do Departamento de Entomologia, Fitopatologia e Zoologia Agrícola da Escola Superior de Agricultura "Luiz de Queiroz", Universidade de São Paulo, em Piracicaba, SP. Foram utilizadas as linhagens de Blattella germanica suscetível (SUS) e resistente a deltametrina (Deltametrina-R). Os procedimentos de criação de $B$. germanica em laboratório e seleção da linhagem Deltametrina-R estão reportados nos Capítulos 3 e 4, respectivamente.

A avaliação da mistura de deltametrina e clorpirifós foi realizada a partir de um bioensaio de contato tarsal com as linhagens SUS e Deltametrina-R. Os tratamentos testados foram (a) $12,5 \mathrm{mg}$ deltametrina $/ \mathrm{m}^{2}$ (K'Othrine $25 \mathrm{CE}$; formulação concentrado emulsionável, $25 \mathrm{~g}$ de deltametrina/L, Aventis Environmental Science); (b) $240 \mathrm{mg}$ clorpirifós $/ \mathrm{m}^{2}$ (Dursban 4E; formulação concentrado emulsionável, $480 \mathrm{~g}$ de clorpirifós/L, Dow AgroSciences Industrial Ltda.); (c) mistura de 12,5 mg deltametrina $+120 \mathrm{mg}$ clorpirifós $/ \mathrm{m}^{2}$; (d) mistura de 12,5 mg deltametrina $+240 \mathrm{mg}$ clorpirifós $/ \mathrm{m}^{2}$ e (e) controle. Os produtos foram diluídos em água destilada e a aplicação foi realizada sobre a superfície de um azulejo $(15 \times 15 \mathrm{~cm})$ através da torre de Potter (Burkard Manufacturing, Rickmansworth, Herts, Reino Unido) calibrada à pressão de 10 psi $(68,95 \mathrm{kPa})$. Um volume de $2 \mathrm{ml}$ de solução foi utilizado em cada pulverização, obtendo-se uma deposição média de resíduo úmido de $1,50 \mathrm{mg} / \mathrm{cm}^{2}$ sobre cada azulejo. No tratamento controle foi realizado a pulverização de apenas água. As pulverizações de todos os azulejos a serem utilizados no experimento foram realizadas no mesmo dia e as infestações de baratas sobre os azulejos tratados foram realizadas no decorrer do tempo para avaliar a persistência biológica dos resíduos de inseticidas. 
As baratas foram previamente separadas (estágio adulto e machos) e confinadas em um recipiente plástico $(500 \mathrm{ml})$ de forma invertida sobre a superfície do azulejo tratado. Cada recipiente apresentava um orifício na base superior e uma camada de vaselina líquida foi untada na borda inferior interna dos recipientes para manter as baratas restritas ao resíduo de inseticida. As infestações foram realizadas aos $0,7,14$, 21, 28, 35 e 42 dias após a pulverização. Para cada tratamento, linhagem e tempo de infestação foram utilizadas 4 repetições de 10 baratas. Após cada infestação, inicialmente foi avaliado o efeito knock-down após 5 minutos em que as baratas ficaram em contato com o resíduo do inseticida. Após 15 minutos, as baratas foram retiradas do resíduo tratado e retornadas para recipientes plásticos $(500 \mathrm{ml})$ limpos com tampa, contendo algodão embebido em água e alimento (ração para cachorro). Os bioensaios foram mantidos em câmara climatizada, regulada à temperatura de $28 \pm 1^{\circ} \mathrm{C}$, umidade relativa de 55 $55 \%$ e fotofase de $12 \mathrm{~h}$. A mortalidade foi avaliada com $24 \mathrm{~h}$ após a infestação, considerando-se como mortas os indivíduos incapazes de se locomoverem normalmente, mostrando evidências de paralisia ou tombamento.

Os dados de mortalidade $(X)$ para cada tratamento foram corrigidos pela fórmula de Abbott (1925), transformados em arco sen $\sqrt{x / 100}$ e submetidos à análise de variância em um delineamento fatorial (tratamento $\times$ linhagem $\times$ idade de resíduo) com interações. O nível de significância dos testes foi de $\alpha=0,05$.

\subsection{Resultados e Discussão}

Os dados de knock-down com 5 minutos e de mortalidade com $24 \mathrm{~h}$ para as linhagens SUS e Deltametrina-R de B. germanica em diferentes idades de resíduo de inseticidas encontram-se na Tabela 14. O efeito knock-down foi observado somente nos tratamentos com deltametrina utilizada isoladamente ou em mistura. As curvas de degradação da persistência biológica dos diferentes tratamentos para as 2 linhagens testadas estão representadas na Figura 11. Os efeitos de tratamento $(\mathrm{F}=281,11$; gl. $=3$, 168; $\mathrm{P}<0,05)$, linhagem $(\mathrm{F}=676,99 ; \mathrm{gl} .=1,168 ; \mathrm{P}<0,05)$ e idade de resíduo $(\mathrm{F}=15,81$; 
$\mathrm{gl}=6,168 ; \mathrm{P}<0,05)$ foram altamente significativos. As interações tratamento $\times$ linhagem $(\mathrm{F}=200,25 ; \mathrm{gl}=3,168 ; \mathrm{P}<0,05)$, tratamentoxidade de resíduo $(\mathrm{F}=3,86 ; \mathrm{gl} .=18,168$; $\mathrm{P}<0,05)$, linhagem $\times$ idade de resíduo $(\mathrm{F}=6,43 ; \quad$ gl. $=6, \quad 168 ; \quad \mathrm{P}<0,05) \quad \mathrm{e}$ tratamento $\times$ linhagem $\times$ idade de resíduo $(\mathrm{F}=7,11 ; \mathrm{gl} .=18,168 ; \mathrm{P}<0,05)$ foram altamente significativos.

O efeito knock-down do produto nem sempre pode ser considerado como a melhor forma de avaliar a sua eficiência, porque este efeito pode não resultar em mortalidade (Tabela 14). Essa tendência foi também verificada por Hemingway et al. (1993b) por meio de um grande número de ninfas de B. germanica com efeito knockdown, mas que posteriormente recuperaram durante um período de $48 \mathrm{~h}$, tanto na linhagem suscetível quanto na resistente a piretróides.

A mortalidade da linhagem SUS foi significativamente maior que o da linhagem Deltametrina-R nos tratamentos de $12,5 \mathrm{mg}$ deltametrina $/ \mathrm{m}^{2}$ e $240 \mathrm{mg}$ clorpirifós $/ \mathrm{m}^{2}$. Os 2 produtos controlaram $100 \%$ de baratas da linhagem SUS até resíduos de 28 dias de idade. A mortalidade da linhagem Deltametrina-R com deltametrina variou de 17 a 20\% nas infestações realizadas aos 0 e 7 dias da pulverização e de 0 a 2,5\% a partir da infestação com resíduos de 14 dias de idade (Tabela 11), comprovando a sobrevivência desta linhagem nas doses de deltametrina recomendada comercialmente devido à resistência. $\mathrm{O}$ inseticida clorpirifós possibilitou um controle de aproximadamente $80 \%$ da linhagem Deltametrina-R nas diferentes idades de resíduo. Como Deltametrina-R não é uma linhagem isogênica, há possibilidade de que genes que conferem resistência ao clorpirifós estejam presentes na linhagem Deltametrina-R, uma vez que a mortalidade máxima foi obtida com clorpirifós na linhagem SUS (Tabela 14, Figura 11).

A mistura de $12,5 \mathrm{mg}$ deltametrina $+120 \mathrm{mg}$ clorpirifós $/ \mathrm{m}^{2}$ possibilitou um bom controle inicial tanto da linhagem SUS como da linhagem Deltametrina-R, porém a partir de resíduos de 14 dias, a discriminação entre as linhagens ficou evidente devido ao decréscimo de sua atividade biológica para a linhagem Deltametrina-R. Diante desses resultados, fica evidente que a mistura de $12,5 \mathrm{mg}$ deltametrina $+120 \mathrm{mg}$ clorpirifós $/ \mathrm{m}^{2}$, que são as doses dos produtos utilizados comercialmente em mistura, não é eficiente 
para o manejo da resistência de $B$. germanica a deltametrina. Por outro lado, o uso da mistura de deltametrina e clorpirifós nas doses dos produtos recomendados isoladamente, ou seja, de 12,5 mg deltametrina $+240 \mathrm{mg}$ clorpirifós $/ \mathrm{m}^{2}$, apresentou um melhor controle das 2 linhagens (Figura 11).

O controle da linhagem SUS foi mais eficiente nas duas proporções de mistura testadas do que nos tratamentos com os produtos isolados. O decréscimo na atividade biológica de deltametrina e clorpirifós foi observado a partir de resíduos de 35 dias de idade para a linhagem SUS. A mortalidade da linhagem SUS foi de 100\% nas duas proporções de mistura avaliadas ao longo do experimento, ou seja, até resíduos de 42 dias de idade.

Segundo os dados obtidos no presente estudo, em situações em que a freqüência de resistência de $B$. germanica a deltametrina ainda é baixa, o uso da mistura de deltametrina e clorpirifós nas duas proporções testadas foi mais eficiente do que os produtos utilizados isoladamente. Porém, em situações em que a freqüência de resistência já se encontra relativamente alta, a mistura nas doses dos produtos recomendadas atualmente não foi suficiente para exercer controle sobre os indivíduos resistentes a deltametrina. $\mathrm{O}$ uso da mistura de deltametrina e clorpirifós cada qual nas doses dos produtos recomendados isoladamente possibilitou um melhor controle da linhagem Deltametrina-R. Porém, a validade dessa recomendação deve ser avaliada em termos de custo, pois segundo Stone et al. (1998), a mistura pode ser vantajosa em certas situações, mas é imprescindível a realização da análise econômica para se adotar esta estratégia, além do risco de uma maior contaminação ambiental com pesticidas. Um outro grande entrave da mistura está na possibilidade de seleção de indivíduos resistentes aos dois produtos simultaneamente, levando à perda dos dois inseticidas no controle de B. germanica.

Uma das condições básicas para o sucesso da mistura é que a freqüência de resistência aos 2 produtos seja baixa (Mani, 1985; Roush, 1989; Tabashnik, 1989) e no caso de B. germanica, as freqüências de resistência já se encontram relativamente altas tanto para a deltametrina como para o clorpirifós nas nossas condições (Capítulos 3 e 4). Portanto, para a recomendação da mistura há necessidade de um monitoramento da 
resistência e utilização dessa estratégia somente em situações em que as freqüências de resistência ainda sejam relativamente baixas aos 2 produtos da mistura.

A atividade biológica dos produtos utilizados em mistura deve ser semelhante para que o princípio básico da mistura seja observado (ou seja, os indivíduos resistentes a um determinado produto sejam controlados pelo produto alternativo, e vice-versa). No caso de deltametrina e clorpirifós, admite-se que o clorpirifós proporcione o controle residual. Nestas condições, verifica-se que o uso de apenas 120 g de clorpirifós (metade da dose recomendada) na mistura com $12,5 \mathrm{mg}$ deltametrina/ $\mathrm{m}^{2}$, a sobrevivência de indivíduos resistentes a deltametrina foi observada logo a partir de resíduos com 14 dias de idade, ao passo que com 240 g clorpirifós na mistura, a seleção a favor de indivíduos resistentes a deltametrina ocorreu somente a partir de resíduos com 42 dias de idade (Figura 11).

A presença de refúgio para indivíduos suscetíveis é uma outra condição para prolongar a vida útil dos produtos utilizados em mistura. Caso ocorra a seleção dos indivíduos resistentes aos dois produtos, a diluição da resistência poderia ser observada com o cruzamento dos indivíduos resistentes selecionados com os suscetíveis provenientes de áreas de refúgio (Georghiou, 1983). No entanto, no caso de controle de B. germanica, a preservação de áreas de refúgio não seria uma alternativa viável.

Sem dúvida, a questão da mistura de produtos deve ser estudada mais detalhadamente em pesquisas futuras. Com a introdução de novos inseticidas para o controle de B. germanica, tais como fipronil, imidacloprid, hidrametilona etc., possivelmente, a opção mais segura para a preservação da vida útil de todos os produtos existentes no mercado seja a rotação de produtos associada às boas práticas de manejo integrado de pragas, considerando-se principalmente a sanitização. 
Tabela 14. Porcentagem de knock-down com 5 min e mortalidade com 24 h nas linhagens suscetível (SUS) e Deltametrina-R de B. germanica em diferentes idades de resíduo de inseticidas.

\begin{tabular}{|c|c|c|c|c|c|}
\hline \multirow[b]{2}{*}{ Tratamento } & \multirow[b]{2}{*}{$\begin{array}{c}\text { Idade do } \\
\text { resíduo } \\
\text { (dias) }\end{array}$} & \multicolumn{2}{|c|}{ SUS } & \multicolumn{2}{|c|}{ Deltametrina-R } \\
\hline & & $\begin{array}{c}\text { \% knock-down } \\
\text { (5 min) }\end{array}$ & $\begin{array}{c}\text { \% mortalidade } \\
\text { (24 h) }\end{array}$ & $\begin{array}{c}\text { \% knock-down } \\
\text { (5 min) }\end{array}$ & $\begin{array}{c}\text { \% mortalidade } \\
\text { (24 h) }\end{array}$ \\
\hline \multirow{7}{*}{$\begin{array}{c}12,5 \mathrm{mg} \\
\text { deltametrina/ } \mathrm{m}^{2}\end{array}$} & 0 & 72,5 & 100 & 62,5 & 17,5 \\
\hline & 7 & 90 & 100 & 43,24 & 21,67 \\
\hline & 14 & 75 & 100 & 7,5 & 2,5 \\
\hline & 21 & 70 & 97,5 & 7,5 & 2,5 \\
\hline & 28 & 62,5 & 100 & 17,5 & 0 \\
\hline & 35 & 42,5 & 77,44 & 5 & 0 \\
\hline & 42 & 65 & 92,44 & 12,5 & 5 \\
\hline \multirow{7}{*}{$\begin{array}{c}240 \mathrm{mg} \\
\text { clorpirifós } / \mathrm{m}^{2}\end{array}$} & 0 & 0 & 100 & 0 & 80 \\
\hline & 7 & 0 & 100 & 0 & 80,56 \\
\hline & 14 & 0 & 100 & 2,5 & 75 \\
\hline & 21 & 0 & 100 & 0 & 72,5 \\
\hline & 28 & 0 & 100 & 0 & 67,5 \\
\hline & 35 & 0 & 74,74 & 0 & 87,5 \\
\hline & 42 & 0 & 100 & 0 & 72,5 \\
\hline & 0 & 70 & 100 & 67,5 & 100 \\
\hline $12,5 \mathrm{mg}$ & 7 & 50 & 100 & 67,5 & 100 \\
\hline deltametrina & 14 & 75 & 100 & 45 & 97,5 \\
\hline+ & 21 & 70 & 100 & 32,5 & 95 \\
\hline $120 \mathrm{mg}$ & 28 & 77,5 & 100 & 35 & 87,5 \\
\hline \multirow[t]{3}{*}{ clorpirifós $/ \mathbf{m}^{2}$} & 35 & 65 & 100 & 7,5 & 52,5 \\
\hline & 42 & 62,5 & 100 & 0 & 27,5 \\
\hline & 0 & 47,5 & 100 & 60 & 100 \\
\hline $12,5 \mathrm{mg}$ & 7 & 85 & 100 & 52,5 & 100 \\
\hline deltametrina & 14 & 65 & 100 & 50 & 100 \\
\hline+ & 21 & 67,5 & 100 & 40 & 100 \\
\hline $240 \mathrm{mg}$ & 28 & 60 & 100 & 20 & 100 \\
\hline \multirow[t]{2}{*}{ clorpirifós $/ \mathbf{m}^{2}$} & 35 & 45 & 100 & 20 & 100 \\
\hline & 42 & 47,5 & 100 & 5 & 97,5 \\
\hline
\end{tabular}



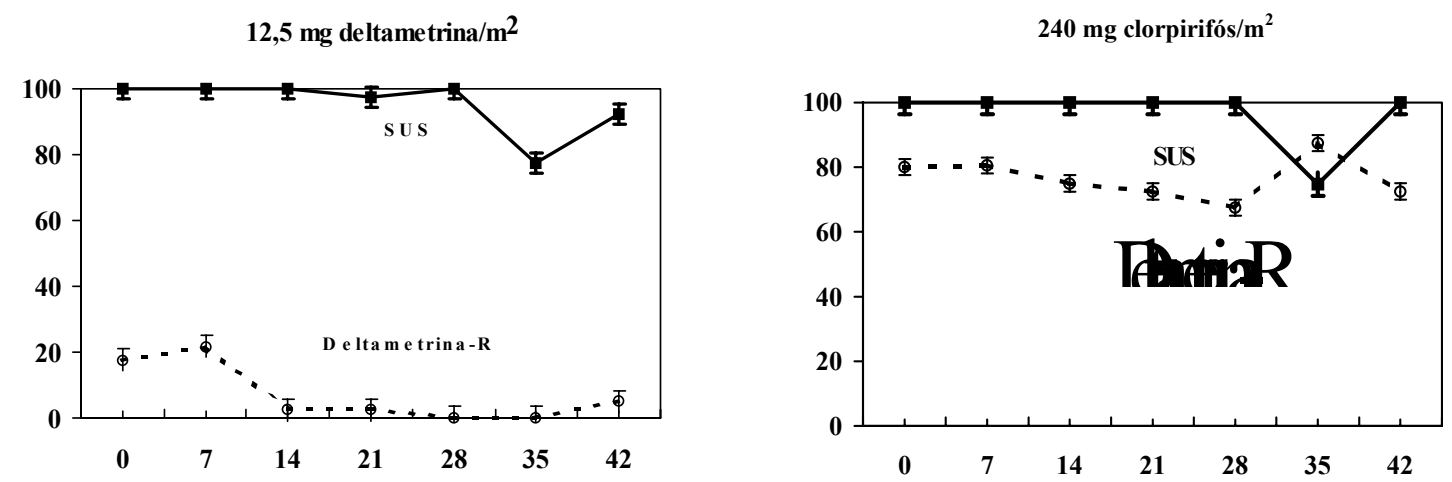

$\frac{\substack{\frac{\pi}{\pi} \\ \frac{\pi}{\pi}}}{\sum^{\frac{\pi}{2}}}$
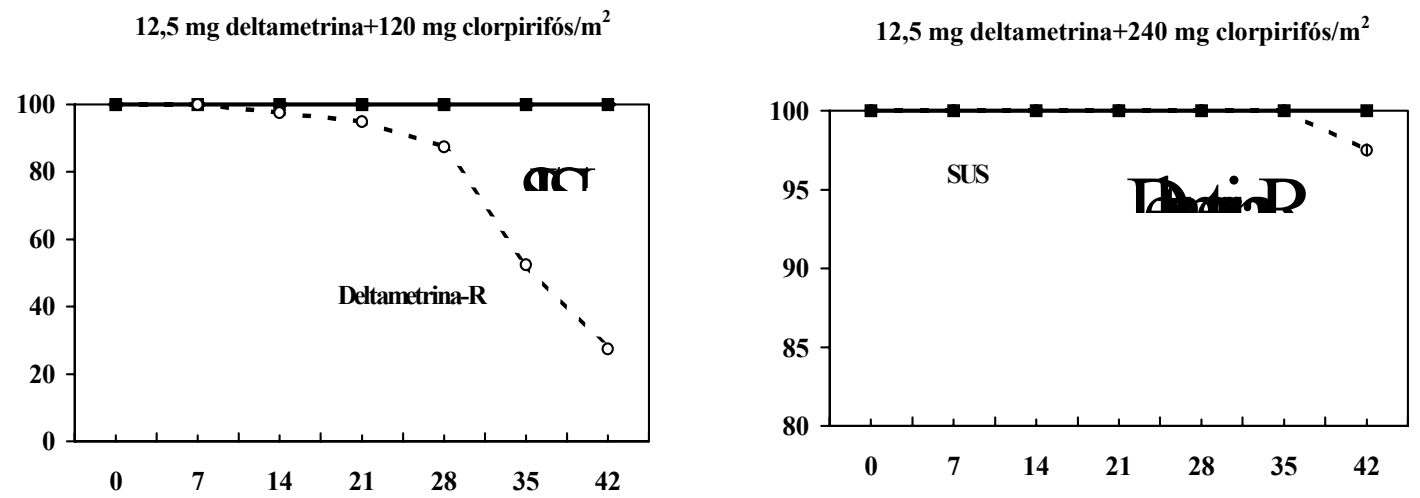

\section{Idade do Resíduo (dias)}

Figura 11 - Mortalidade das linhagens suscetível (SUS) (ロ) e Deltametrina-R (O) de $B$. germanica em diferentes idades de resíduo de inseticidas.

\subsection{Conclusões}

- A mistura de $12,5 \mathrm{mg}$ deltametrina $+120 \mathrm{mg}$ de clorpirifós $/ \mathrm{m}^{2}$ não é eficiente no manejo da resistência de Blattella germanica a deltametrina. 


\section{CONCLUSÕES GERAIS}

- O bioensaio de aplicação tópica é mais eficiente do que o bioensaio de contato tarsal para detectar a resistência em populações de Blattella germanica a deltametrina e clorpirifós.

- Há diferenças na suscetibilidade de populações de $B$. germanica testadas a deltametrina, clorpirifós e fipronil.

- As razões de resistência de $B$. germanica aos inseticidas deltametrina e clorpirifós foram de aproximadamente 43 e 6 vezes, respectivamente.

- A resistência de $B$. germanica a deltametrina foi instável na ausência de pressão seletiva.

- Baixa intensidade de resistência cruzada foi detectada entre fipronil e os inseticidas deltametrina e clorpirifós em B. germanica.

- A mistura de $12,5 \mathrm{mg}$ deltametrina $+120 \mathrm{mg}$ de clorpirifós $/ \mathrm{m}^{2}$ não é eficiente no manejo de resistência de $B$. germanica a deltametrina. 


\section{REFERÊNCIAS BIBLIOGRÁFICAS}

ABBOTT, W.S. A method of computing the effectiveness of an insecticide. Journal of Economic Entomology, v.18, p.265-267, 1925.

APPEL, A.G. Blattella and related species. In: RUST, M.K.; OWENS, J.M.; REIERSON, D.A.(Ed.). Understanding and controlling the german cockroach. Cambridge: Oxford University Press, 1995. p. 1-20.

ATKINSON, T.H.; WADLEIGH, R.W.; KOEHLER, P.G.; PATTERSON, R.S. Pyrethroid resistance and synergism in a field strain of the German cockroach (Dictyoptera: Blattellidae). Journal of Economic Entomology, v.84, n.4, p.12471250, Aug. 1991.

BENNET, G.W.; OWENS, J.M.; CORRIGAN, R.M. Guia cientifica de Truman para operaciones de control de plagas. 4.ed. Trad. de R. Ituarte. Cleveland: Advanstar Comunications, $1996.510 \mathrm{p}$.

BLOOMQUIST, J.R.; FERGUSON, H.J.; COX, E.D.; REDDY, M.S.; COOK, J.M. Mode of action of $\beta$-carboline convulsants on the insect nervous system and their potential as insecticides. Pesticide Science, v.51, p.1-6, 1997. 
BLOOMQUIST, J.R.; ROBINSON, W.H.; ROBINSON, W.H. (ED.); RETTICH, F. (ED.); RAMBO, G.W. Prevalence and magnitude of resistance to Cyclodiene and Phenylpyrazole insecticides in Blattella germanica and Drosophila melanogaster. In: 3., INTERNATIONAL CONFERENCE ON URBAN PESTS, Prague, 1999. Proceedings. Prague: Czech University of Agriculture, 1999. p.27-34.

BRENNER, R.J. Economics and medical importance of German cockroaches. In: RUST, M.K.; OWENS, J.M.; REIERSON, D.A. Understanding and controlling the German cockroach. Cambridge: Oxford University Press, 1995. p.77-92.

BRETT, B.L.; ROSS, M.H. Behavioral responses of the German cochroach Blattella germanica (L.) (Orthoptera: Blattellidae), to a Propoxur formulations. Journal of Economic Entomology, v.79, n.2, p.426-430, Apr. 1986.

BROWN, A.W.A.; PAL, R. Resistência de los artropodos a los insecticidas.. Genebra: Organization Mundial de la Salud, 1973. 544 p.

BYFORD, R.L.; LOCKWOOD, J.A.; SMITH, S.M.; SPARKS. T.C.; LUTHER, D.G. Insecticide mixtures as an approach to the management of the Pyrethroid - resistant Horn Flies (Diptera: Muscidae). Journal of Economic Entomology, v.80, n.1, p.111-116, Feb. 1987.

CHILCUTT, C.F.; TABASHINK, B.E. Evolution of pesticide resistance and slope of the concentration-mortality line: are they related? Journal of Economic and Entomology, v.88, n.1, p.11-20, Feb. 1995.

COCHRAN, D.G. Cochroaches: biology and control. Genebra: World Health Organization, 1982. 53 p. 
COCHRAN, D.G. Effects of synergists on Bendiocarb and Pyrethrins resistance in the German Cockroach (Dictyoptera: Blattellidae). Journal of Economic Entomology, v.80, n.4, p.728-732, Aug. 1987a.

COCHRAN, D.G. Selection of Pyrethroid resistance in the German Cockroach Blattella germanica (L.) (Dictyoptera: Blattellidae). Journal of Economic Entomology, v. 80, n.6, p.1117-1121, Dec. 1987b.

COCHRAN, D.G. Monitoring for insecticide resistance in field-collected "strains" of the German Cockroach (Dictyoptera: Blattellidae). Journal of Economic Entomology, v. 82, n.2, p.337-341, Apr. 1989.

COCHRAN, D.G. Extended selections for Pyrethroid resistance in the German cockroach (Dictyoptera: Blattellidae). Journal of Economic Entomology, v.84, n.5, p.1412-1416, Oct. 1991.

COCHRAN, D.G. Decline of Pyrethroid resistance in the ausence of selection pressure in a population of German cockroach (Dictyoptera: Blattellidae). Journal of Economic Entomology, v.86, n.6, p.1639-1644, Dec. 1993.

COCHRAN, D.G. Abamectin resistance potential in the German Cockroach (Dictyoptera: Blattellidae). Journal of Economic Entomology, v.87, n.4, p.899903, Aug. 1994a.

COCHRAN, D.G. Effects of three synergists on Pyrethroid resistance in the German cockroach (Dictyoptera: Blattellidae). Journal of Economic Entomology, v.87, n.4, p.879-884, Aug. 1994b. 
COCHRAN, D.G. Insecticide resistance. In: RUST, M.K.; OWENS, J.M.; REIERSON, D.A. Understanding and controlling the German cockroach. Cambridge: Oxford University Press, 1995. p.171-192.

COCHRAN, D.G. Relevance of resistance ratios to operacional control in the German Cockroach (Dictyoptera: Blattellidae). Journal of Economic Entomology, v.89, n.2, p.318-321, Apr. 1996.

COCHRAN, D.G. Misuse of the tarsal-contact method for detecting insecticide resistance in the German Cockroach (Dictyoptera: Blattellidae). Journal of Economic Entomology, v.90, n.6, p.1441-1444, Dec. 1997.

COCHRAN, D.G. Cockroaches: their biology, distribution and control. Genebra: WHO, $1999.83 \mathrm{p}$.

COLLINS, W.J. German cockroach Resistance. 1. Resistance to Diazinon includes cross-Resistance to DDT, Pyrethrins and Propoxur in a laboratory colony. Journal of Economic Entomology, v.66, n.1, p.44-47, Feb. 1973.

COLLINS, W.J. Resistance in Blattella germanica (L.) (Orthoptera, Blattellidae): the effect of Propoxur selection and non-selection on the resistance spectrum developed Diazinon selection. Bulletin of Entomological Research, v.65, p.399-403, 1975.

CORNWELL, P.B. The cockroach: a laboratory insect and an industrial pest. London: The Rentokil Library, 1968. v.1, 391 p.

CORNWELL, P.B. The cockroach: inseticides and cockroach control. London: The Rentokil Library, 1976. v.2, 557 p. 
CROFT, B.A.; VAN DE BAAN, H.E. Ecological and genetic factors influencing evolution of pesticide resistance in tetranychid and phytoseiid mites. Experimental \& Applied Acarology, v.4, p.277-300, 1988.

DENHOLM, I.; CAHILL, M.; DENNEHY, T.J.; HOROWITZ, A.R. Challenges with managing insecticide resistance in agricultural pests, exemplified by the whitefly Bemisia tabaci. In: DENHOLM, I.; PICKETT, J.A.; DEVONSHIRE, A.L. (Ed.). Insecticide resistance: from mechanisms to management. London: The Royal Society; CABI Publishing, 1999. p.81-92.

DENNEHY, T.J.; GRANETT, J.; LEIGH, T. F. Relevance of slide-dip and residual bioassay comparisions to detection of resistance in spider mites. Journal of Economic Entomology, v.76, n.4, p.1225-1230, Oct. 1983.

DURIER, V.; RIVAULT, C. Secondary transmission of toxic baits in German cochroach (Dictyoptera: Blattellidae). Journal of Economic Entomology, v.93, n.2, p.434440, Apr. 2000.

EBBETT, R.; COCHRAN, D.G. Inheritance of resistance to Pyrethroids in the German cockroach (Dictyoptera: Blattellidae). Journal of Economic Entomology, v.90, n.6, p.1458-1461, Dec. 1997.

EL-SAYED, G.N.; KNOWLES, C.O. Formamidine synergism of Pyrethroid toxicity to twospotted spider mites (Acari: Tetranychidae). Journal of Economic Entomology, v.77, n.1, p.23-30, Feb. 1984.

FFRENCH-CONSTANT, R.H.; ROUSH, R.T. Resistance detection and documentation: the relative roles of pesticidal and biochemical assays. In: ROUSH, R.T.; TABASHNIK, B.E. (Ed.). Pesticide resistance in arthropods. New York: Chapman and Hall, 1990. p.4-38. 
GAHLHOFF Jr, J.E.; MILLER, D.M.; KOEHLER, P.G. Secondary kill of adult male German cockroaches (Dictyoptera: Blattellidae) via cannibalism of nymphs fed toxic baits. Journal of Economic Entomology, v.92, n.5, p.1133-1137, Oct.1999.

GEORGHIOU, G.P. The evolution of resistance to pesticidas. Annual Review of Ecology and Systematics, v.3, p.133-168, 1972.

GEORGHIOU, G.P. Management of resistance in arthropods. In: GEORGHIOU, G.P.; SAITO, T. Pest resistance to pesticides. New York: Plenum, 1983. p.769-792.

GEORGHIOU, G.P. The magnitude of the resistance problem. In: NATIONAL RESEARCH COUNCIL. Pesticide resistance: strategies and tactics for management. Washington: National Academy of Scince, 1986. p. 14-43.

GEORGHIOU, G.P.; LAGUNES-TEJEDA, A. The occurrence of resistance to pesticides in Arthropods. Rome: FAO, 1991. 318 p.

GEORGHIOU, G.P.; TAYLOR, C.E. Genetic and biological influences in the evolution of insecticide resistance. Journal of Economic Entomology, v.70, n.3, p.319-323, June 1977a.

GEORGHIOU, G.P.; TAYLOR, C.E. Operacional influences in the evolution of insecticide resistance. Journal of Economic Entomology, v.70, n.5, p.653-658, Oct. $1977 b$.

GRAYSON, J.M. Differences between a resistant and a non-resistant strain of the German cockroach. Journal of Economic Entomology, v.47, n.2, p.253-256, Apr. 1954. 
GUIMARÃES, J.H. Baratas: manejo integrado em áreas urbanas. Agroquímica CIBAGEIGY, n.25, p.20-24, 1984.

HALLIDAY, W.R.; BURNHAM, K.P. Choosing the optimal diagnostic dose for monitoring insecticide resistance. Journal of Economic Entomology, v.83, n.4, p.1151-1159, Aug. 1990.

HARMON, J.D.; ROSS, M.H. Effects of Malathion and Diazinon exposure on female German cockroaches (Dictyoptera: Blattellidae) and their oothecae. Proceedings of the Entomological Society of Washington, v.90, n.2, p.248-255, 1988.

HEMINGWAY, J.; SMALL, G.J.; MONRO, A.G. Possible mechanisms of organophosphorus and carbamate insecticide resistance in German cockroaches (Dictyoptera: Blattellidae) from different geographical areas. Journal of Economic Entomology, v.86, n.6, p.1623-1630, Dec. 1993a.

HEMINGWAY, J.; DUNBAR, S.J.; MONRO, A.G.; SMALL, G.J. Pyrethroid resistance in German cockroaches (Dictyoptera: Blattellidae): resistance levels and underlying mechanisms. Journal of Economic Entomology, v.86, n.6, p.1631-1638, Dec. $1993 b$.

HOSKINS, W.M.; GORDON, H.T. Arthropod resistance to chemicals. Annual Review of Entomology, v.1, p.89-122, 1956.

HOSTETLER, M.E.; BRENNER, R.J. Behavioral and phisiological resistance to insecticide in the German cockroach (Dictyoptera: Blattellidae). Journal of Economic Entomology, v.87, n.4, p.885-893, Aug. 1994. 
HUANG, G.; LIU, J.M.; LIU, W.Y. Resistance to five pesticides of Blattella germanica from cities of Hebei Province. Chinese Journal of Vector Biology and Control, v.10, n.4, p.285-287, 1999. /Resumo em CAB Abstracts-1998/08-2000/07/

KAAKEH, W.; REID, B.L.; BENNETT, G.W. Toxicity of Fipronil to German and American cockroaches. Entomologia Experimentalis et Applicata, v.84, p.229237, 1997.

KELlER, J.C.; CLARK, P.H.; LOFGREN, C.S.; WILSON, H.G. Results of USDA-s sponsored research on cockroach control. Pest Control, v.24, n.12.14,17,19-20, Sept. 1956.

KOEHLER, P.G.; PATTERSON, R.S.; BRENNER, R.J. Cockroaches. In: MALIS, A. Handbook of pest control: the behavior, life history and control of household pests. 7.ed. Cleveland: Franzak \& Foster, 1990. p.101-174.

LADONNI, H. Susceptibility of different field strains of Blattella germanica to four pyrethroids (Orthoptera: Blattellidae). Iranian Journal of Public Health, v.26, n.1, p.3/4, 35-40, 1997. /Resumo em CAB Abstracts-1998/08-2000/07/

LADONNI, H. Evaluation of three methods for detecting Permethrin resistance in adult and nymphal Blattella germanica (Dictyoptera: Blattellidae). Journal of Economic Entomology, v.94, n.3, p.694-697, June 2001.

LEE, C.Y.; YAP, H.H.; CHONG, N.L. Insecticide resistance and sinergism in field collected German cockroaches (Dictyoptera: Blattellidae) in Peninsular Malaysia. Bulletin of Entomological Research, v.86, p.675-682, 1996.

LEORA SOFTWARE. POLO-PC: a user's guide to probit or logit analysis. Berkely, 1987. 20p. 
LIN, L.F.; LU, W.C.; CAI, S.W. Monitoring for insecticide resistance in field-collected strains of the German cockroach in Guangdong. Chinese Journal of Vector Biology and Control, v.11, n.1, p.32-34, 2000. /Resumo em CAB Abstracts1998/08-2000/07/

LOCKWOOD, J.A.; SPARKS, T.C.; STORY, R.N. Evolution of insect resistance to insecticides: a reevaluation of the roles of physiology and behavior. Bulletin of the Entomological Society of America, v.30, n.3, p.41-51, Aug. 1984.

LOCKWOOD, J.A.; BYFORD, R.L.; STORY, R.N.; SPARKS, T.C.; QUISENBERRY, S.S. Behavioral resistance to the pyrethroids in the horn fly, Haematobia irritans (Diptera: Muscidae). Environmental Entomology, v.14, n.6, p.873-880, Dec. 1985.

MAcDONALD, R.S.; SURGEONER, G.A.; SOLOMON, K.R.; HARRIS, C.R. Development of resistance to Permethrin and Dichlorvos by the house fly (Diptera: Muscidae) following continuous and alternating insecticide use on four farms. Canadian Entomologist, v.115, p.1555-1561, 1983.

MANI, G.S. Evolution of resistance in the presence of two insecticides. Genetics, v.109, p.761-783, Apri, 1985.

MARTINEZ-TORRES, D.; DEVONSHIRE, A.L.; WILLIAMSON, M.S. Molecular studies of knockdown resistance to pyrethroids: cloning of domain II sodium channel gene sequences from insects. Pesticide Science, v.51, p.265-270, 1997.

MATSUMURA, F. Toxicology of insecticides. New York: Plenum Press, 1985. 503 p.

METZGER, R. Behavior. In: RUST, M.K.; OWENS, J.M.; REIERSON, D.A. Understanding and controlling the German cockroach. Cambridge: Oxford University Press, 1995. p.49-76. 
MILIO, J.F.; KOEHLER, P.G.; PATTERSON, R.S. Evaluation of three methods for detecting Chlorpyrifos resistance in German Cockroach (Orthoptera: Blattellidae) populations. Journal of Economic Entomology, v.80, n.1, p.44-46, Feb. 1987.

NATIONAL PESTICIDE TELECOMMUNICATIONS NETWORK. Fipronil. Oregon State University, Corvallis, Oregon http://ace.orst.edu/info/nptn (26 Nov. 1999)

OMOTO, C. Resistência de pragas urbanas a inseticidas. In: SIMPÓSIO LATINO AMERICANO SOBRE CONTROLE DE PRAGAS URBANAS, São Paulo, 1996. Anais. São Paulo: 1996. p.95-98.

ORGANIZAÇÃO MUNDIAL DE SAÚDE. Resistencia a los Insecticidas y lucha contra los vetores: $17^{\circ}$ informe. Ginebra, 1970. 306p. (Serie de Informes Tecnicos, 443).

PAGANELLI, C.H. Baratas urbanas: biologia e controle. Boletim Técnico APRAG, n. 3, pp. 1-26, Abr., 1997.

PIMENTEL, D.; BURGESS, M. Effects of single versus combinations of insecticides on the development of resistance. Environmental Entomology, v.14, p.582-589, 1985.

PLAPP Jr., F.W.; CAMPANHOLA, C.; BAGWELL, R.D.; McCUTCHEON, B.F. Management of pyrethroid-resistant tobbaco budworms on cotton in the United States. In: ROUSH, R.T.; TABASHNIK, B.E. (Ed.). Pesticide resistance in arthropods. New York: Chapman and Hall, 1990. p.237-260.

PLUTHERO, F. G.; SINGH, R. S. Insect behavioral responses to toxins: practical and evolutionary considerations. The Canadian Entomologist, v.116, n.1, p.57-68, Jan. 1984. 
PRABHAKARAN, S.K.; KAMBLE, S.T. Activity and eletrophoretic characterization of esterases in insecticide-resistant and susceptible strains of German cockroach (Dictyoptera: Blattellidae). Journal of Economic Entomology, v.86, n.4, p.10091013, Aug. 1993.

ROBINSON, W.H. Urban entomology: insect and mite pests in the human environment. London: Chapman \& Hall, 1996. 430 p.

ROSS, M.H. Diferences in the response of German Cochroaches (Dictyoptera: Blattellidae) field strains to vapors of pyrethroid formulations. Journal of Economic Entomology, v.85, n.1, p.123-129, Feb. 1992.

ROSS, M.H. Evolution of behavioral resistance in German Cochroaches (Dictyoptera: Blattellidae) selected with a toxix bait. Journal of Economic Entomology, v.90, n.6, p.1482-1485, Dec. 1997.

ROSS, M.H. Response of behaviorally resistant German Cochroaches (Dictyoptera: Blattellidae) to the active ingredient in a comercial bait. Journal of Economic Entomology, v.91, n.1, p.150-152, Feb. 1998.

ROSS, M.H.; MULLINS, D.E. Biology. In: RUST, M.K.; OWENS, J.M.; REIERSON, D.A. Understanding and controlling the German cockroach. Cambridge : Oxford University Press, 1995. p.21-47.

ROTH, L.M.; WILLIS, E.R. The biotic association of cockroaches. Washington: Smithsonian Institute, 1960. 439 p.

ROUSH, R.T. Designing resistance management programs: How can you choose? Pesticide Science, v.26, p.423-441, 1989. 
ROUSH, R.T.; DALY, J.C. The role of population genetics in resistance research and management. In: ROUSH, R.T.; TABASHNIK, B. E. (Ed.). Pesticide resistance in arthropods. New York: Chapman and Hall, 1990. cap. 5, p.97-152.

ROUSH, R.T.; McKENZIE, J.A. Ecological genetics of insecticide and acaricide resistance. Annual Review of Entomology, v.32, p.361-380, 1987.

ROUSH, R.T.; MILLER, G.L. Considerations for design of insecticide resistance monitoring programs. Journal of Economic Entomology, v.79, n.2, p.293-298, Apr. 1986.

ROUSH, R.T.; TABASHNIK, B.E. (Ed.). Pesticide resistance in arthropods. New York: Chapman and Hall, 1990, 303 pp.

RUST, M.K.; REIERSON, D.A. Chlorpyrifos resistance in German Cockroaches (Dictyoptera: Blattellidae) from restaurants. Journal of Economic Entomology, v.84, n.3, p.736-740, 1991.

SCHAL, C. Relation among efficacy of insecticides, resistance levels and sanitation in the control of the German Cockroach (Dictyoptera: Blattellidae). Journal of Economic Entomology, v.81, n.2, p.536-544, Apr. 1988.

SCHAL, C.; HAMILTON, R.L. Integrated suppression of synanthropic cockroaches. Annual Review of Entomology, v.35, p.521-551, 1990.

SCHARF, M.E.; BENNETT, G.W.; REID, B.L.; QUI, C. Comparisions of three insecticides resistance detection methods for the German cockroach (Dictyoptera: Blattellidae). Journal of Economic Entomology, v.88, n.3, p.536-542, Jun. 1995. 
SCHARF, M.E.; NEAL, J.J.; MARCUS, C.B.; BENNETT, G.W. Cytochrome P450 purification and immunological detection in an insecticide resistant strain of German cockroach (Blattella germanica, L.). Insecticide Biochemistry Molecular Biology, v.28, n.1, p.1-9, 1998.

SCOTT, J.G. Effect of temperature on the toxicity of S-bioallethrin and cypermethrin to susceptible and kdr-resistant strains of Blattella germanica (L.) (Dictyoptera: Blattellidae). Bulletin of the Entomological Research, v.77, p.431-435, 1987.

SCOTT, J.G.; WEN, Z. Toxicity of Fipronil to susceptible and resistant strains of German cockroach (Blattella germanica) and house fly (Musca domestica). Journal of Economic Entomology, v.90, n.5, p.1152-1156, Oct. 1997.

SCOTT, J.G.; COCHRAN, D.G.; SIEGFRIED, B.D. Insecticide toxicity, synergism, and resistance in the German cockroach (Dictyoptera: Blattellidae). Journal of Economic Entomology, v.83, n.5, p.1698-1703, Oct. 1990.

SCOTT, J.G.; RAMASWAMY, S.B.; MATSUMURA, F.; TANAKA, K. Effect of method of application on resistance to pyrethroid insecticides in Blattella germanica (Orthoptera: Blattellidae). Journal of Economic Entomology, v.79, n.3, p.571-575, June. 1986.

SIEGFRIED, B.D.; SCOTT, J.G. Insecticide resistance mechanisms in the German cockroach, Blattella germanica (L.). In: MULLIN, C.A.; SCOTT, J.G. Molecular mechanisms of insecticide resistance: diversity among insects, New York: American Chemical Society, 1992. p.219-230. (ACS. Symposium Series, 505)

SILVERMAN, J.; LIANG, D. Effect of Fipronil on bait formulation-based aversion in the German cockroach (Dictyoptera: Blattellidae). Journal of Economic Entomology, v.92, n.4, p.886-889, Aug. 1999. 
SILVERMAN, J.; ROSS, M.H. Behavioral resistance of field-collected German cockroaches (Blattodea: Blattellidae) to baits containing glucose. Environmental Entomology, v.23, n.2, p.425-430, Apr. 1994.

SPARKS, T.C.; LOCKWOOD, J.A.; BYFORD, R.L.; GRAVES, J.B.; LEONARD, B. R. The role of behavior in insecticide resistance. Pesticide Science, v.26, p.383-399, Feb. 1989.

STONE, N.D.; MAKELA, M.E.; PLAPP Jr, F.W. Nonlinear optimization analysis of insecticide mixtures for the control of tobacco budworm (Lepidoptera: Noctuidae). Journal of Economic Entomology, v.81, n.4, p.989-994, Aug. 1988.

STRONG, C.A.; KOEHLER, P.G.; PATTERSON, R.S. Insecticide resistance: decline and selection in laboratory-reared German cockroaches (Dictyoptera: Blattellidae). Journal of Economic Entomology, v.90, n.1, p.183-187, Feb. 1997.

TABASHNIK, B.E. Managing resistance with multiple pesticide tactics: theory, evidence, and recommendations. Journal of Economic Entomology, v.82, n.5, p.1263-1269, Oct. 1989.

VALLES, M.V. Toxicological and biochemical studies with field populations of the German Cockroach, Blattella germanica. Pesticide Biochemistry and Physiology, v.62, p.190-200, 1998.

VALLES, M.V. $\lambda$-Cyalothrin resistance detection in the German Cockroach (Blattodea: Blattellidae). Journal of Economic Entomology, v.92, n.2, p.293-297, Apr. 1999.

VALLES, M.V.; KOEHLER, P.G. Influence of carbon Dioxide anesthesia on Chlorpyrifos toxicity in the German Cockroach (Dictyoptera: Blattellidae). Journal of Economic Entomology, v.87, n.3, p.709-713, June 1994. 
VALLES, S.M.; BRENNER, R.J. Variation in Hydramethylnon susceptibility among insecticide-resistant German Cockroaches (Blattodea: Blattellidae). Journal of Economic Entomology, v.92, n.3, p.617-623, June 1999.

VALLES, S.M.; YU, S.J. Detection and biochemical characterization of insecticide resistance in the German Cockroach (Dictyoptera: Blattellidae). Journal of Economic Entomology, v.89, n.1, p.21-26, Feb. 1996.

VALLES, S.M.; KOEHLER, P.G.; BRENNER, R.J. Antagonism of Fipronil toxicity by Piperonyl Butoxide and S,S,S-Tributyl Phosphorotrithioate in the German Cockroach (Dictyoptera: Blattellidae). Journal of Economic Entomology, v.90, n.5, p.12541258, Oct. 1997.

VALLES, S.M.; SÁNCHEZ-ARROYO, H.; BRENNER, R.J.; KOEHLER, P.G. Temperature effects on $\lambda$-Cyhalothrin toxicity in insecticide-susceptible and resistant German Cockroaches (Dictyoptera: Blattellidae). Florida Entomologist, v.81, n.2, p.193-201, June 1998.

WADLEIGH, R.W.; KOEHLER, P.G.; PATTERSON, R.S. Comparative susceptibility of North American Blattella (Ortoptera: Blattellidae). Journal of Economic Entomology, v.82, n.4, p.1130-1133, Aug. 1989.

WEN, Z.; SCOTT, J.G. Cross-resistance to Imidacloprid in strains of German cockroach (Blattella germanica) and house fly (Musca domestica). Pesticide Science, v.49, p.367-371, 1997.

ZHAI, J.; ROBINSON, W.H. Measuring Cypermethrin resistance in the German cockroach (Orthoptera: Blattellidae). Journal of Economic Entomology, v.85, n.2, p.348-351, Apr. 1992. 
ZHAI, J.; ROBINSON, W.H. Instability of Cypermethrin resistance in a field population of the German Cockroach (Orthoptera: Blattellidae). Journal of Economic Entomology, v.89, n.2, p.332-336, Apr. 1996.

ZHANG, D.Y.; CHENG, J.A.; WU, H.M.; MAO, H.J. The insecticides resistance of German cockroach Blattella germanica L. and the role of mixed function oxidase in insecticides resistance. Journal of Zhejiang Agricultural University, v.25, n.3, p.303-306, 1999. /Resumo em CAB Abstracts-1998/08-2000/07/ 
APÊNDICE 
APÊNDICE 1 Histórico da resistência de Blattella germanica a inseticidas (Georghiou \& Lagunes - Tejeda, 1991)

\begin{tabular}{|c|c|c|c|}
\hline Grupo químico & Produto & Ano & Local \\
\hline \multirow[t]{2}{*}{ Ciclodienos } & Clordane & 1953 & Corpus Christi (Texas) \\
\hline & DDT & 1959 & Trinidad/França/Alemanha \\
\hline \multirow[t]{4}{*}{ Organoclorados } & $\mathrm{BHC}$ & 1961 & Canadá/Alemanha \\
\hline & Lindane & 1962 & Japão \\
\hline & Diazinon & 1961 & Kentucky (USA) \\
\hline & Malation & 1965 & Texas (USA) \\
\hline \multirow[t]{4}{*}{ Organofosforados } & Fention & 1965 & Texas (USA) \\
\hline & Clorpirifós & 1980 & Canadá \\
\hline & Triclorfon & 1984 & ex Tchecoslováquia \\
\hline & Propoxur & 1968 & Lousiana (USA) \\
\hline \multirow[t]{4}{*}{ Carbamatos } & Bendiocarbe & 1978 & Reino Unido \\
\hline & Dioxicarbe & 1983 & Reino Unido \\
\hline & Tetrametrina & 1979 & ex-URSS \\
\hline & Aletrina & 1980 & Canadá \\
\hline \multirow[t]{3}{*}{ Piretróides } & Ciflutrina & 1988 & Kentucky (USA) \\
\hline & Fenvalerate & 1988 & Kentucky/Virginia(USA) \\
\hline & Permetrina & 1988 & Kentucky(USA) \\
\hline Piretrinas & Piretrinas & 1956 & Alabama (USA) \\
\hline
\end{tabular}

